Prepared in cooperation with the Northwest Indian Fisheries Commission

\title{
Analysis of Low Flows and Selected Methods for Estimating Low-Flow Characteristics at Partial-Record and Ungaged Stream Sites in Western Washington
}

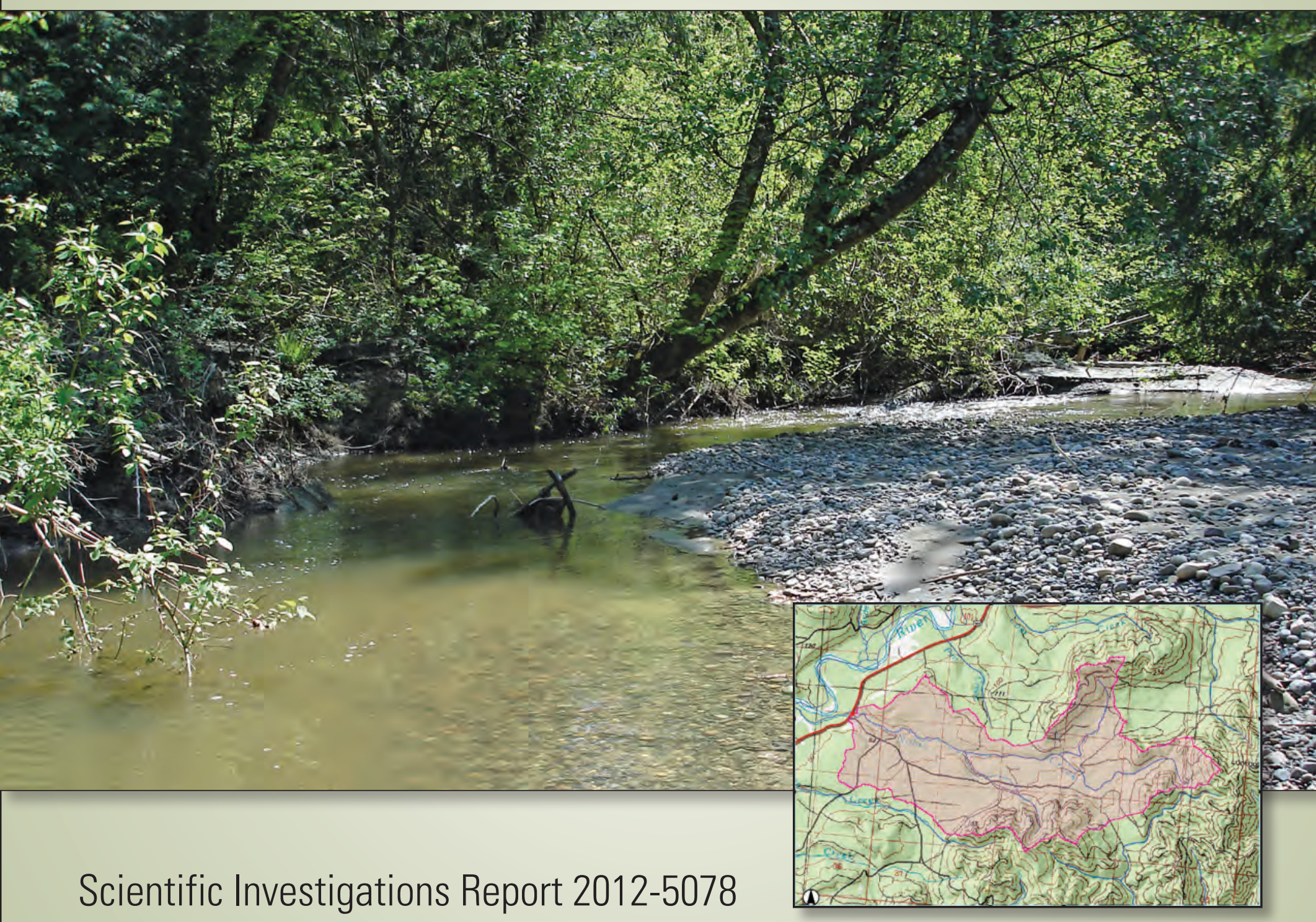





\section{Analysis of Low Flows and Selected Methods for Estimating Low-Flow Characteristics at Partial-Record and Ungaged Stream Sites in Western Washington}

By Christopher A. Curran, Ken Eng, and Christopher P. Konrad

Prepared in cooperation with the Northwest Indian Fisheries Commission

Scientific Investigations Report 2012-5078 


\title{
U.S. Department of the Interior \\ KEN SALAZAR, Secretary \\ U.S. Geological Survey \\ Marcia K. McNutt, Director
}

\author{
U.S. Geological Survey, Reston, Virginia: 2012
}

For more information on the USGS - the Federal source for science about the Earth, its natural and living resources, natural hazards, and the environment, visit http://www.usgs.gov or call 1-888-ASK-USGS.

For an overview of USGS information products, including maps, imagery, and publications, visit http://www.usgs.gov/pubprod

To order this and other USGS information products, visit http://store.usgs.gov

Any use of trade, product, or firm names is for descriptive purposes only and does not imply endorsement by the U.S. Government.

Although this report is in the public domain, permission must be secured from the individual copyright owners to reproduce any copyrighted materials contained within this report.

Suggested citation:

Curran, C.A., Eng, Ken, and Konrad, C.P., 2012, Analysis of low flows and selected methods for estimating low-flow characteristics at partial-record and ungaged stream sites in western Washington: U.S. Geological Survey Scientific Investigations Report 2012-5078, 46 p. 


\section{Contents}

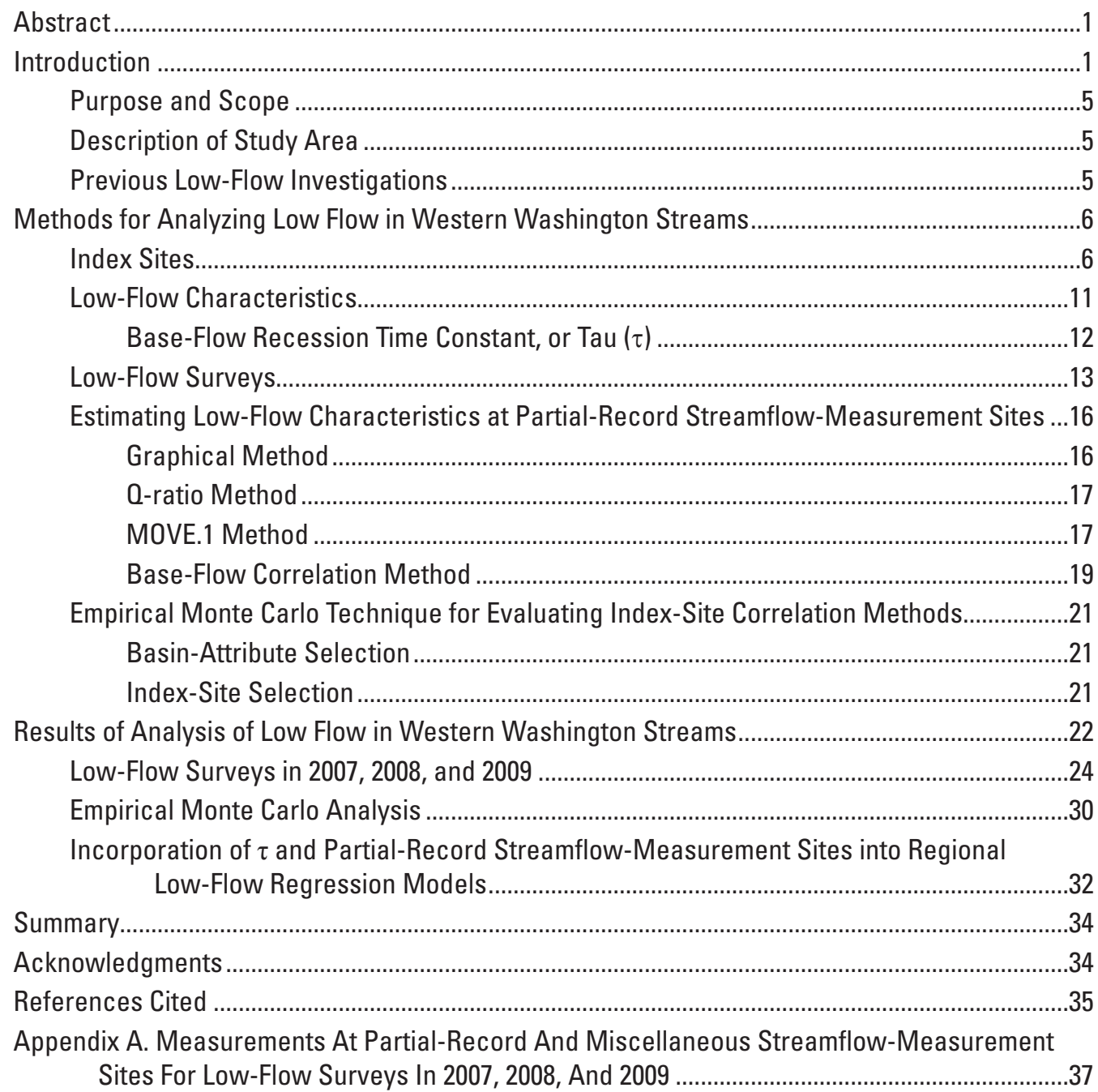




\section{Figures}

Figure 1. Map showing study area in western Washington .....

Figure 2. Graph showing an example of the annual series of 7-day low flows fitted to the log-Pearson type III distribution for the calculation of $\mathrm{Q}_{7,10}$, computed from the streamflow record at the streamflow-gaging station Huge Creek near Wauna, Washington (U.S. Geological Survey station No. 12073500), 1947-69 and 1977-2007

Figure 3. Graph showing base-flow hydrographs and corresponding values of $\tau$ calculated from a single period of base-flow recession at two U.S. Geological Survey streamflow-gaging stations in western Washington, Satsop River near Satsop, 12035000 and Racehorse Creek near Kendall, 12206900

Figure 4. Map showing locations of 63 partial-record and miscellaneous sites at which low-flow measurements were made by the Northwest Indian Fisheries Commission (NWIFC), NWIFC-member tribes, Point-No-Point Treaty Council, and the U.S. Geological Survey (USGS) from 2007 to 2009, and 43 USGS continuous streamflow-gaging stations (index sites) in western Washington

Figure 5. Photographs showing examples of streamflow measurements made during the 2007-09 low-flow surveys of western Washington streams: Squaxin Tribe technical staff measures flow on Schneider Creek, Thurston County, Washington, and Point-No-Point Treaty Council technical staff measures flow on Thomas Creek, Kitsap County, Washington

Figure 6. Example of graphical method used to estimate low-flow characteristics at a partial-record site (Nolan Creek, Jefferson County, Washington) from concurrent base flows at an index site (U.S. Geological Survey gaging station No.12043000, Calawah River near Forks, Washington) where the base-flow relation is non-linear

Figure 7. Graph showing range of mean monthly streamflow as a fraction of mean annual streamflow for the period of record at 43 index sites in western Washington

Figure 8. Graph showing monthly mean streamflow during July-September in 2007-09 as a fraction of mean monthly streamflow for the period of record at 43 index sites in western Washington....

Figure 9. Graphs showing streamflows at 43 index sites median 7-day low flow $\left(0_{7}\right)$ versus streamflow exceeded 90 percent of the time, and lowest average 7-day low flow that recurs on average every 10 years $\left(0_{7,10}\right)$ versus streamflow exceeded 99 percent of the time

Figure 10. Graph showing relation between low-flow characteristics $\left(0_{7,10}\right)$ and selected basin attributes (basin area times mean annual precipitation) of index, partial-record, and miscellaneous sites in western Washington

Figure 11. Graph showing root-mean square error of three correlation methods (0-ratio, MOVE.1, and Base-Flow Correlation) in estimating the $0_{7,10}$ at partial-record sites in western Washington, using scenarios defined by the number of streamflow observations ( $\mathrm{n}$ ) and the combination of basin attributes used to select an index site 


\section{Figures-Continued}

Figure 12. Graph showing overall bias associated with three index-site correlation methods (0-ratio, MOVE.1, Base-Flow Correlation) in estimating the $0_{7,10}$ at partial-record sites in western Washington, using scenarios defined by the number of streamflow observations and the combination of basin attributes used to select an index site

Figure 13. Graph showing root-mean square error of regression models for estimating the $0_{7,10}$ at ungaged sites in western Washington, using different combinations of explanatory variables and numbers of paired streamflow measurements ..... 33

Figure 14. Graph showing coverage of basin-attribute variable space defined by basin area and $\tau$ for index sites and partial-record sites established during 2007-09 low-flow surveys in western Washington

\section{Tables}

Table 1. Definitions used to reference types of streamflow sites in western Washington used for this study

Table 2. Location, low-flow characteristics, and basin attributes for 43 index sites on streams in western Washington

Table 3. Example of the use of the 0-ratio method to estimate low-flow characteristics at a partial-record site (Cabin Creek, Jefferson County, Washington) on the basis of concurrent low-flow characteristics at an index site (U.S. Geological Survey gaging station No. 12073500, Huge Creek near Wauna, Washington)

Table 4. Example of the use of the MOVE. 1 method to estimate the $0_{7,10}$ at a partial-record site (Winfield Creek, Jefferson County, Washington) from concurrent low flows at an index site (U.S. Geological Survey gaging station No. 12043000, Calawah River near Forks, Washington) ....

Table 5. Example of the Base-Flow Correlation method for estimating the $0_{7,10}$ at a partial-record site (Dan Creek, Snohomish County, Washington) from concurrent flows at an index site (U.S. Geological Survey gaging station No. 12137290, South Fork Sultan River near Sultan, Washington)

Table 6. Basin attributes and data sources used for index-site selection in the empirical Monte Carlo analysis and for developing preliminary regional low-flow regressions for western Washington

Table 7. Location, number of measurements, and estimates of $\tau$ and $0_{7,10}$ at partial-record and miscellaneous sites established by the Northwest Indian Fisheries Commission (NWIFC), NWIFC-member tribes, Point-No-Point Treaty Council, and U.S. Geological Survey as part of the low-flow surveys conducted in western Washington during 2007-09....

Table 8. Location and basin attributes for partial-record and miscellaneous sites established by the Northwest Indian Fisheries Commission (NWIFC), NWIFC-member tribes, Point-No-Point Treaty Council, and U.S. Geological Survey as part of low-flow surveys conducted in western Washington during 2007-09 


\title{
Conversion Factors and Datums
}

\author{
Conversion Factors
}

\begin{tabular}{|c|c|c|}
\hline Multiply & By & To obtain \\
\hline \multicolumn{3}{|c|}{ Length } \\
\hline inch (in.) & 2.54 & centimeter (cm) \\
\hline inch (in.) & 25.4 & millimeter (mm) \\
\hline foot (ft) & 0.3048 & meter $(\mathrm{m})$ \\
\hline mile (mi) & 1.609 & kilometer (km) \\
\hline \multicolumn{3}{|c|}{ Area } \\
\hline square foot $\left(\mathrm{ft}^{2}\right)$ & 0.09290 & square meter $\left(\mathrm{m}^{2}\right)$ \\
\hline square mile $\left(\mathrm{mi}^{2}\right)$ & 2.590 & square kilometer $\left(\mathrm{km}^{2}\right)$ \\
\hline \multicolumn{3}{|c|}{ Flow rate } \\
\hline foot per second (ft/s) & 0.3048 & meter per second $(\mathrm{m} / \mathrm{s})$ \\
\hline cubic foot per second ( $\mathrm{ft}^{3} / \mathrm{s}$ ) & 0.02832 & cubic meter per second $\left(\mathrm{m}^{3} / \mathrm{s}\right)$ \\
\hline inch per year (in/yr) & 25.4 & millimeter per year (mm/yr) \\
\hline $\begin{array}{l}\text { cubic foot per second per square } \\
\text { mile }\left[\left(\mathrm{ft}^{3} / \mathrm{s}\right) / \mathrm{mi}^{2}\right]\end{array}$ & 0.01093 & $\begin{array}{l}\text { cubic meter per second per square } \\
\text { kilometer }\left[\left(\mathrm{m}^{3} / \mathrm{s}\right) / \mathrm{km}^{2}\right]\end{array}$ \\
\hline million gallons per day (Mgal/d) & 0.04381 & cubic meter per second $\left(\mathrm{m}^{3} / \mathrm{s}\right)$ \\
\hline
\end{tabular}

Temperature in degrees Fahrenheit $\left({ }^{\circ} \mathrm{F}\right)$ may be converted to degrees Celsius $\left({ }^{\circ} \mathrm{C}\right)$ as follows:

${ }^{\circ} \mathrm{C}=\left({ }^{\circ} \mathrm{F}-32\right) / 1.8$.

Datums

Vertical coordinate information is referenced to the North American Vertical Datum of 1988 (NAVD 88).

Horizontal coordinate information is referenced to the North American Datum of 1983 (NAD 83).

Elevation, as used in this report, refers to distance above the vertical datum. 


\title{
Analysis of Low Flows and Selected Methods for Estimating Low-Flow Characteristics at Partial-Record and Ungaged Stream Sites in Western Washington
}

\author{
By Christopher A. Curran, Ken Eng, and Christopher P. Konrad
}

\section{Abstract}

A regional low-flow survey of small, perennial streams in western Washington was initiated by the Northwest Indian Fisheries Commission (NWIFC), NWIFC-member tribes, and Point-No-Point Treaty Council in cooperation with the U.S. Geological Survey in 2007 and repeated by the tribes during the low-flow seasons of 2008-09. Low-flow measurements at 63 partial-record and miscellaneous streamflow-measurement sites during surveys in 2007-09 are used with concurrent flows at continuous streamflow-gaging stations (index sites) within the U.S. Geological Survey network to estimate the low-flow metric $Q_{7,10}$ at each measurement site $\left(Q_{7,10}\right.$ is defined as the lowest average streamflow for a consecutive 7-day period that recurs on average once every 10 years). Index-site correlation methods for estimating low-flow characteristics at partialrecord sites are reviewed and an empirical Monte Carlo technique is used with the daily streamflow record at 43 index sites to determine the error and bias associated with estimating the $\mathrm{Q}_{7,10}$ at synthetic partial-record sites using three methods: Q-ratio, MOVE.1, and Base-Flow Correlation. The Q-ratio method generally has the lowest error and least amount of bias for 170 scenarios, with each scenario defined by the number of concurrent flow measurements between the partial-record and index sites (ranging from 4 to 20) and the combination of basin attributes used to select the index site. The root-mean square error for the Q-ratio method ranged from 70 to 118 percent, depending on the scenario. The scenario with the smallest root-mean square error used four concurrent flow measurements and the basin attributes: basin area, mean annual precipitation, and base-flow recession time constant, also referred to as tau $(\tau)$.

Regional low-flow regression models for estimating $\mathrm{Q}_{7,10}$ at ungaged stream sites are developed from the records of daily discharge at 65 continuous gaging stations (including 22 discontinued gaging stations) for the purpose of evaluating explanatory variables. By incorporating the base-flow recession time constant $\tau$ as an explanatory variable in the regression model, the root-mean square error for estimating $\mathrm{Q}_{7,10}$ at ungaged sites can be lowered to 72 percent (for known values of $\tau$ ), which is 42 percent less than if only basin area and mean annual precipitation are used as explanatory variables. If partial-record sites are included in the regression data set, $\tau$ must be estimated from pairs of discharge measurements made during continuous periods of declining low flows. Eight measurement pairs are optimal for estimating $\tau$ at partial-record sites, and result in a lowering of the root-mean square error by 25 percent. A low-flow survey strategy that includes paired measurements at partial-record sites requires additional effort and planning beyond a standard strategy, but could be used to enhance regional estimates of $\tau$ and potentially reduce the error of regional regression models for estimating low-flow characteristics at ungaged sites.

\section{Introduction}

Low-flows are an important part of the natural flow regime of rivers and streams. Ecologically, low flows maintain longitudinal connectivity in the stream channel, allowing fish migration and nutrient transport, as well as the preservation of aquatic, riparian, and hyporheic (below streambed) ecosystems. In western Washington (fig. 1), groundwater discharge, or base flow, is the primary component of low flows in many lowland rivers and streams (Sinclair and Pitz, 1999). In mountain streams, however, meltwater from glaciers or snow fields can dominate low flows, especially during summer months. Low flows in western Washington typically occur during extended dry periods in the late summer and early autumn, but also can occur during cold, dry periods in midwinter, particularly at higher-elevation streams. In developed areas, low flows can be altered by many factors, including surface-water diversions, return flows, groundwater pumping, reservoir operations, and land use, all of which can influence water availability for people, fish, and ecosystems. 


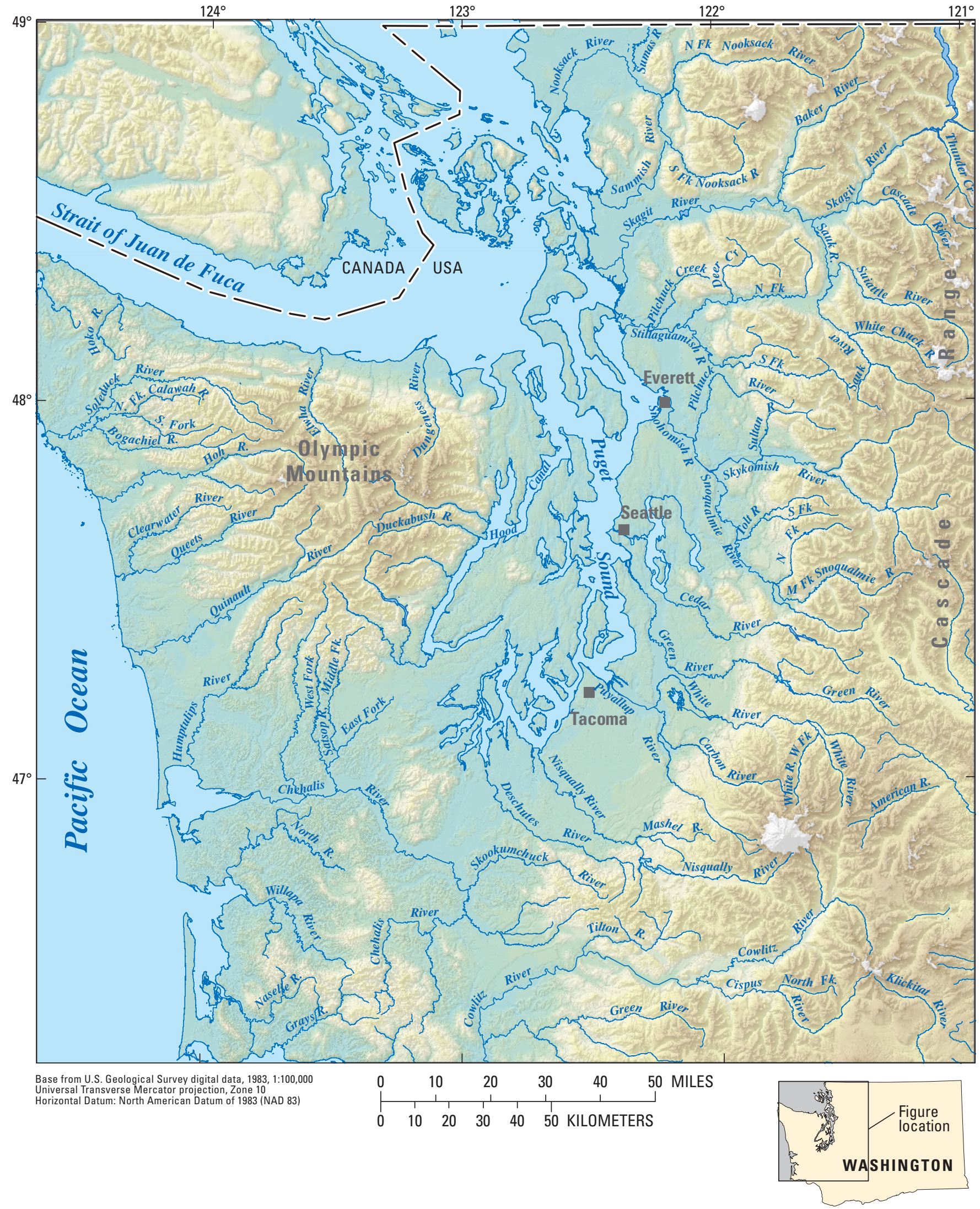

Figure 1. Study area in western Washington. 
Native American tribes in western Washington have reserved water rights that are needed to support their growing populations, and the tribes have treaty rights to harvestable salmon, which also need water for successful spawning, hatching, rearing, and migration. Competing demands between out-of-stream and in-stream water uses, as well as between the water needs of tribes and non-tribal entities, are most profound in western Washington during late summer and early autumn, when streamflow is generally lowest. Information on low flows during this time is crucial for the optimal management of water resources.

As part of a scientific framework for assessing water resources in western Washington (Konrad, 2005), the documentation of low-flow conditions in western Washington streams was identified by the Northwest Indian Fisheries Commission (NWIFC) and its member tribes as a high priority for several reasons. First, documentation of low-flow conditions can be used to map the spatial extent of perennially aquatic habitats in stream networks. These habitats support fish populations, some invertebrate taxa, and biogeochemical processes. Second, streamflow measurements under lowflow conditions can be used to identify areas and rates of groundwater discharge, which helps maintain critical thermal refugia for salmonids; information about groundwater discharge also can be used to assess the potential effect of current and future groundwater withdrawals. Lastly, extended periods of low flow in streams offer an opportunity for regionally coordinated data collection and efficient regionalscale regression analysis. The results of the analysis can be extrapolated across the region to estimate streamflow under low-flow conditions with quantified error at any site.

To document low flows, a regional low-flow survey of small streams was initiated by NWIFC and NWIFC-member tribes and the Point-No-Point Treaty Council (PNPTC) in cooperation with the U.S. Geological Survey (USGS) in 2007, and repeated by the tribes during the low-flow seasons (July through September) of 2008 and 2009. A regional low-flow survey results in streamflow data from numerous locations and watershed types over the course of a season, typically summer. The data can be efficiently analyzed to document base-flow conditions and characteristics for small ungaged streams, which are underrepresented within the continuous streamflow-gaging-station network of western Washington. Of the 357 USGS-operated gaging stations with at least 10 years of continuous data, only 56 are in drainage areas less than $10 \mathrm{mi}^{2}$ (M.C. Mastin, U.S. Geological Survey, written commun., 2011).
A low-flow survey supports the regional analysis of streamflow in three ways:

1. multiple measurements collected over different years can be used to estimate low-flow characteristics at a site, extend the coverage (geographic and basin-type) of the existing streamflow-gaging-station network, and, potentially, assess streamflow trends over time;

2. paired measurements made during a period of continuously decreasing streamflow (base-flow recession) can be used to estimate the base-flow recession time constant, $\tau$, which can serve as an explanatory variable in low-flow regression models; and

3. single measurements can be used to verify regional regression estimates of low-flow characteristics at a site.

For the purposes of the analyses described in this report, four categories of stream sites are defined (table 1): (1) an index site is a site with a continuous streamflow-gaging station with 10 or more years of daily streamflow record under natural flow conditions and with minimal flow contributions from glacial processes or effects of anthropogenic alteration of flow; (2) a partial-record site is a site with four or more streamflow measurements made during a period of 2 or more years; (3) a miscellaneous site is a site with streamflow measurements that are not continuous and the site does not qualify as a partial-record site; and (4) an ungaged site is a site at which no streamflow measurements have been made.

Low-flows measured at partial-record and miscellaneous sites can be correlated with concurrent flows at selected index sites to estimate low-flow characteristics such as the $\mathrm{Q}_{7,10}$ (defined as the lowest average streamflow for a consecutive 7 -day period that recurs on average once every 10 years). The low-flow characteristics that are estimated at partial-record sites can be used in site-specific studies for establishing in-stream water needs or assessing the ability to meet outof-stream demands. Partial-record sites established as part of the low-flow survey also can be incorporated into regional regression models for estimating low-flow characteristics at ungaged sites. 


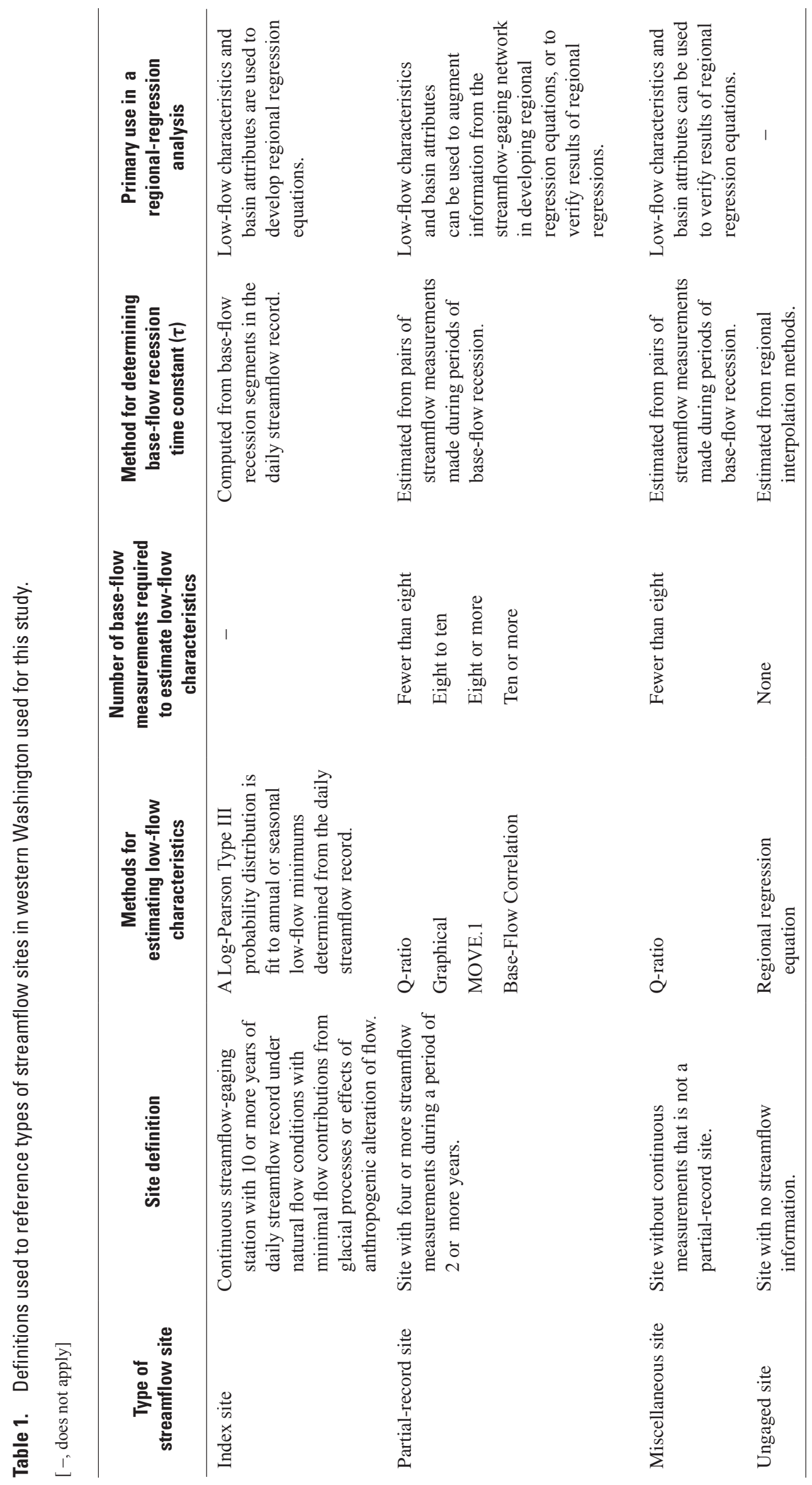




\section{Purpose and Scope}

This report documents the low-flow conditions in western Washington streams measured by NWIFCmember tribes during late-summer surveys in 2007, 2008, and 2009, describes and evaluates methods for estimating low-flow characteristics (specifically the $\mathrm{Q}_{7,10}$ ) at these sites, and identifies research and data needs for developing future regional regression models for estimating low-flow characteristics at ungaged sites in western Washington.

The $\mathrm{Q}_{7,10}$ is determined at 43 continuous streamflowgaging stations within the USGS network in western Washington that represent relatively natural and unimpaired streamflow conditions (index sites) with a glacial meltwater component that is minimal to nonexistent. Low flows measured at partial-record and miscellaneous sites during the 2007-09 surveys are correlated with the concurrent dailymean flows at index sites, and the $\mathrm{Q}_{7,10}$ is estimated at the partial-record and miscellaneous sites. Basin attributes (for example, latitude and longitude, basin area, and mean annual precipitation) are determined for all sites to assess information gaps in the network. An empirical Monte Carlo technique is used to determine the error and bias associated with three commonly used index-site correlation methods for estimating low-flow characteristics (Q-ratio, MOVE.1, and Base-Flow Correlation [Potter, 2001; Hirsch, 1982; and Stedinger and Thomas, 1985, respectively]), and the optimal number of measurements for estimating the $\mathrm{Q}_{7,10}$ at partial-record sites is determined. Regional low-flow regressions for estimating the $\mathrm{Q}_{7,10}$ at ungaged sites are developed for the purpose of evaluating explanatory variables. The types of additional partial-record sites needed to improve regional low-flow regressions for estimating low-flow characteristics at ungaged sites in western Washington also are assessed.

\section{Description of Study Area}

The study area in western Washington State extends westward from the crest of the Cascade Range (fig. 1). This region includes mountains (the Olympic Mountains and Cascade Range) as well as coastal lowlands and nearshore areas along the Pacific Ocean and Puget Sound. The Cascade Range is a magmatic arc formed by the subduction of an oceanic plate beneath the continental crust and its western assemblage of sedimentary and volcanic rocks is of Eocene through early Miocene age (Jones, 1999). The Olympic Mountains are the product of tectonic uplift caused by the subduction of the Juan de Fuca Plate beneath the North American Plate. The comparatively flat Puget Sound lowland lies within the forearc basin formed between colliding plates and has been largely shaped by numerous Pleistocene glaciations, which deposited thick layers of glacial outwash interspersed with layers of till (Dragovich and others, 1997). The surficial geology of the basin reflects the history of mountain building, erosional and depositional processes such as landslides and lahars, and fluvial processes that erode, transport, and deposit sediment in post-glacial terrain (Linneman and others, 2007).

The climate of western Washington is maritime, with lowland areas experiencing mild, wet winters and generally cool, dry summers. The topography ranges in elevation from sea level to about $3,800 \mathrm{ft}$ on average in the Olympic Mountains and about 6,200 ft on average along the crest line of the Cascade Range. The sharp contrast in topography combined with prevailing patterns of moist wind from the Pacific Ocean create orographic-lift conditions that result in higher precipitation in mountainous areas (as much as about $200 \mathrm{in} / \mathrm{yr}$ on average) relative to lowland areas near Puget Sound (about $40 \mathrm{in} / \mathrm{yr}$ on average). Most precipitation in the mountains occurs as snow, and in the lowlands precipitation is dominated by rain. Land cover in the region is predominantly forested in mountain and upland areas, with developed and agricultural lands dominating the lowland areas. The population of western Washington is about 5 million, which is concentrated along the corridor connecting Everett, Seattle and Tacoma (U.S. Census Bureau, 2000). Out-of-stream water use in the region is estimated at $1,350 \mathrm{Mgal} / \mathrm{d}$, about 60 percent of which is supplied by surface water and about 40 percent by groundwater (Lane, 2009).

\section{Previous Low-Flow Investigations}

The USGS has conducted regional-scale investigations of low flow across the United States, many for the purpose of developing regional regression models for estimating low-flow statistics at ungaged sites (Ries and Friesz, 2000; Hortness, 2006; Funkhouser and others, 2008; Risley and others, 2008). The application of index-site correlation methods for estimating low-flow characteristics at partial-record sites is well-documented in many of these studies. Previous lowflow investigations in western Washington have ranged from basin- to regional-scale, with a focus on computing low-flow frequency statistics, quantifying low-flow characteristics through various indices, or examining base-flow components of the hydrograph. Most studies in Washington State have relied heavily, if not solely, on streamflow information collected at USGS gaging stations that are part of the national hydrologic data network. Hidaka (1973) computed low-flow indices for streams in the Puget Sound region from flowfrequency curves and determined that low-flow characteristics were different for mountain and lowland streams largely due to snowmelt contributions to mountain streams, and characteristics for lowland streams varied according to basin elevation. Other researchers (Collings and Hidaka, 1974; Cummans, 1977; Haushild and LaFrance, 1977; Williams and others, 1985a, 1985b; Curran and Olsen, 2009) calculated low-flow frequency statistics for streams in selected basins or subregions of western Washington. Sinclair and Pitz (1999) computed base-flow characteristics for all USGS gaging stations in Washington and characterized the degree of streamflow alteration and the dependence of low flows on snowmelt processes. 


\section{Methods for Analyzing Low Flow in Western Washington Streams}

In this study, low-flow surveys were conducted on perennial streams in western Washington that are not monitored as part of the USGS continuous streamflow-gagingstation network. Because low flows are less variable on an annual basis than high flows, partial records consisting of a small number of measurements at some stream sites can be used in concert with long-term, continuous streamflow records from other sites in a regional low-flow analysis. Partial records are related to continuous records at an index site to estimate low-flow characteristics at the partial-record site, and the results are used in turn to augment the data set available for developing regression models for estimating low-flow characteristics at ungaged sites. Thus, partial-record sites offer an affordable way to expand the geographic coverage of low-flow information and include combinations of basin attributes (for example, small, low-elevation streams) that are underrepresented in the streamflow-gaging network.

\section{Index Sites}

An index site is a site with a continuously recording streamflow-gaging station that measures 'natural' or otherwise unimpaired (without anthropogenic alterations such as flow regulation or diversions) flow conditions in a basin, and for which a sufficient length of record exists for computing lowflow characteristics. In this study, 43 index sites were selected from the USGS streamflow-gaging network in western Washington and the data from those sites were used to:

- document regional hydrologic conditions during the low-flow surveys,

- estimate low flow at partial-record and miscellaneous sites,

- evaluate index-site correlation methods, and

- develop preliminary regional low-flow regression models.
Index sites were initially screened on the basis of the following criteria: (1) they have 10 or more years of continuous daily streamflow record, (2) they represent perennially flowing streams or rivers with a $\mathrm{Q}_{7,10}$ greater than zero, (3) they represent relatively natural streamflow conditions, and (4) they represent streams in which low flow is predominantly groundwater-derived (base flow), and glacier meltwater, if a contributor to streamflow, is only a minor component of flow at the site. This last criterion is necessary because glacial meltwater augments flows in many streams during the typical summer low-flow season in western Washington.

Because the number of small stream sites in the study area satisfying the first criterion was insufficient, three sites with 8 years of record and one site with 7 years also were used in the analysis. Additionally, Sinclair and Pitz (1999) identified many of the sites used in this analysis as having some potential for anthropogenic alteration or glacier meltwater contribution to base flow, but these effects were assumed to be minor at such sites. Non-USGS streamflow-gaging stations (for example, gaging stations operated by the Washington State Department of Ecology [Ecology], local governments, or tribes) were not included in this study either due to the brevity of their flow records, altered flow conditions at the gaging station (for example, most Ecology gaging stations monitor anthropogenic effects), or uncertainties in data quality and availability.

Basin attributes, such as basin area, mean annual precipitation, and mean basin elevation, were determined for all 43 index sites using the USGS Washington StreamStats program, a web-based interactive tool (U.S. Geological Survey, 2010). The basin attributes and low-flow characteristics for each index site are listed in table 2. 


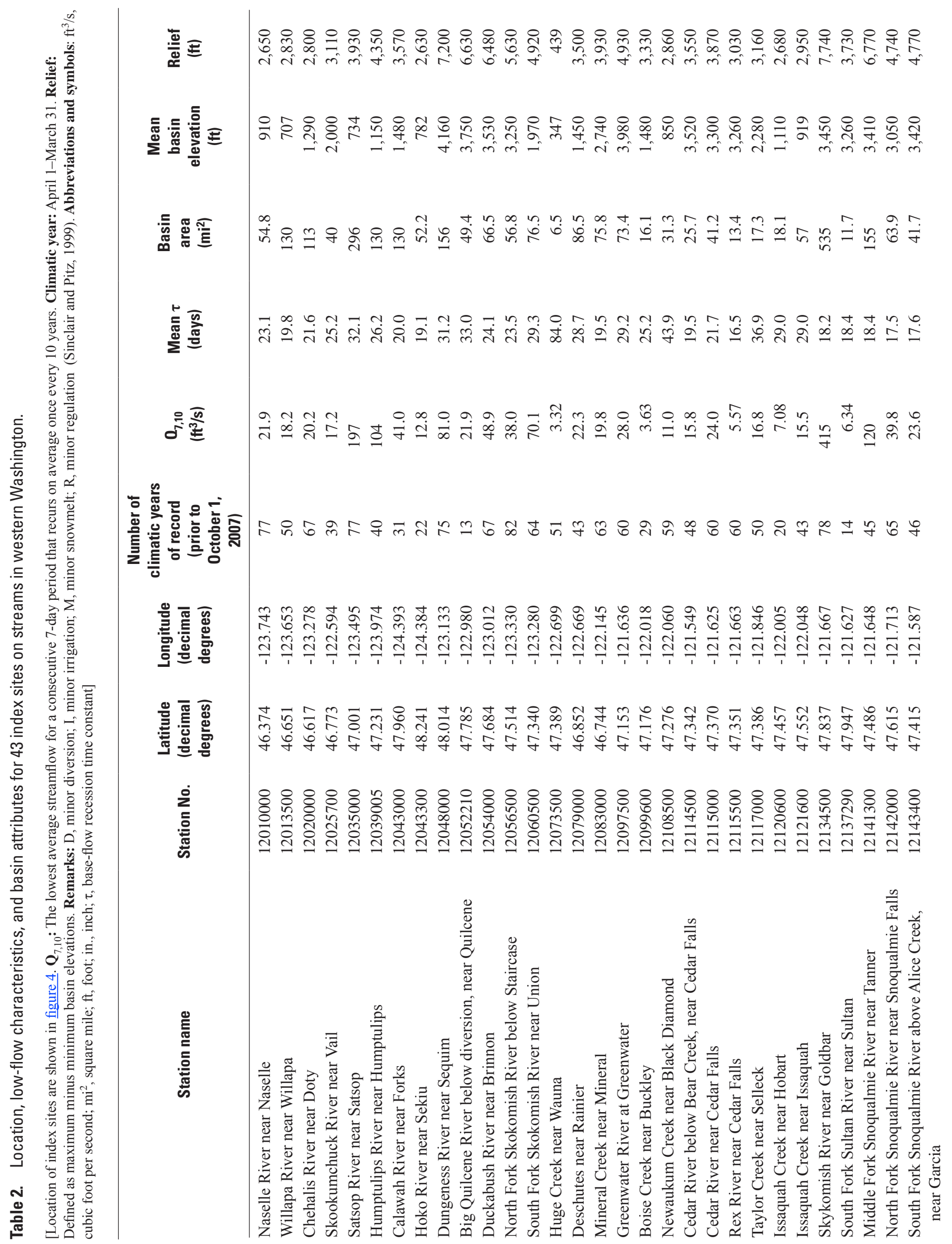




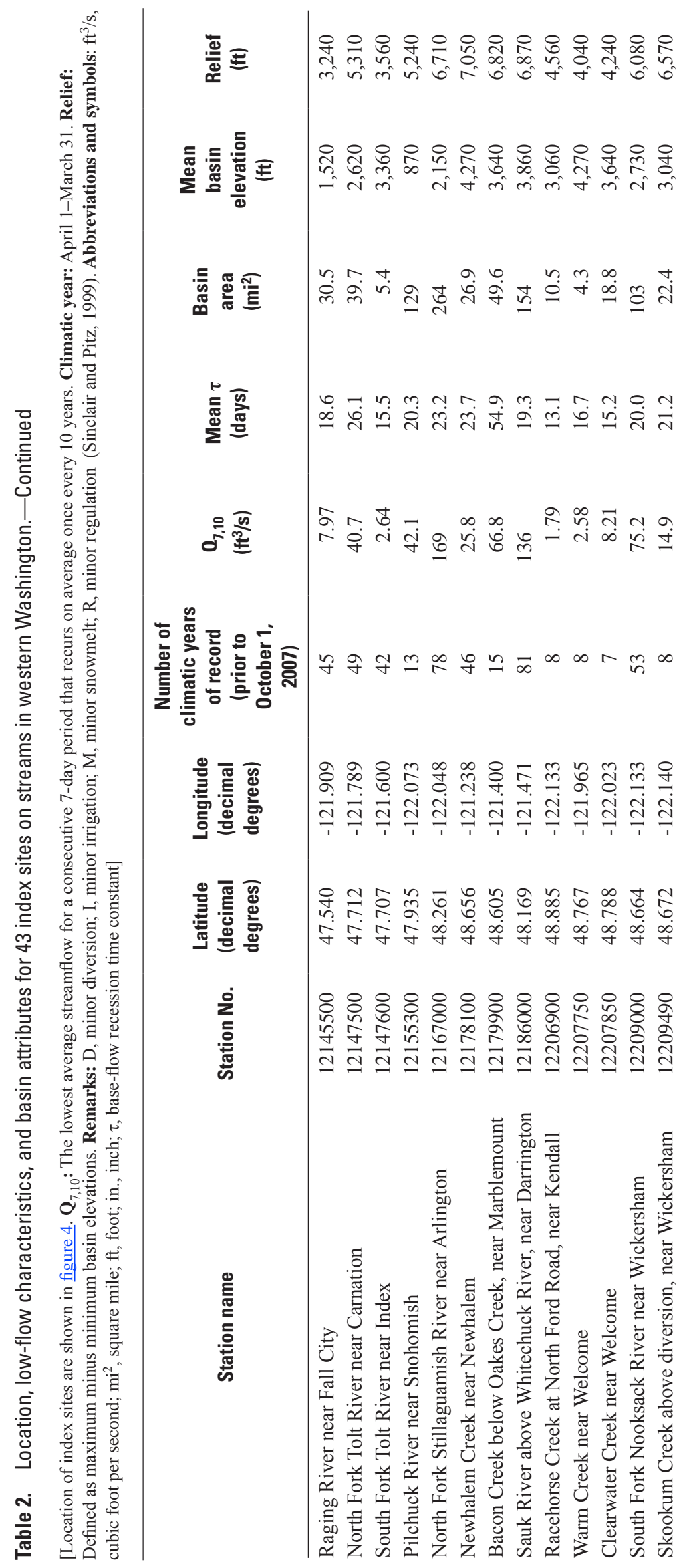




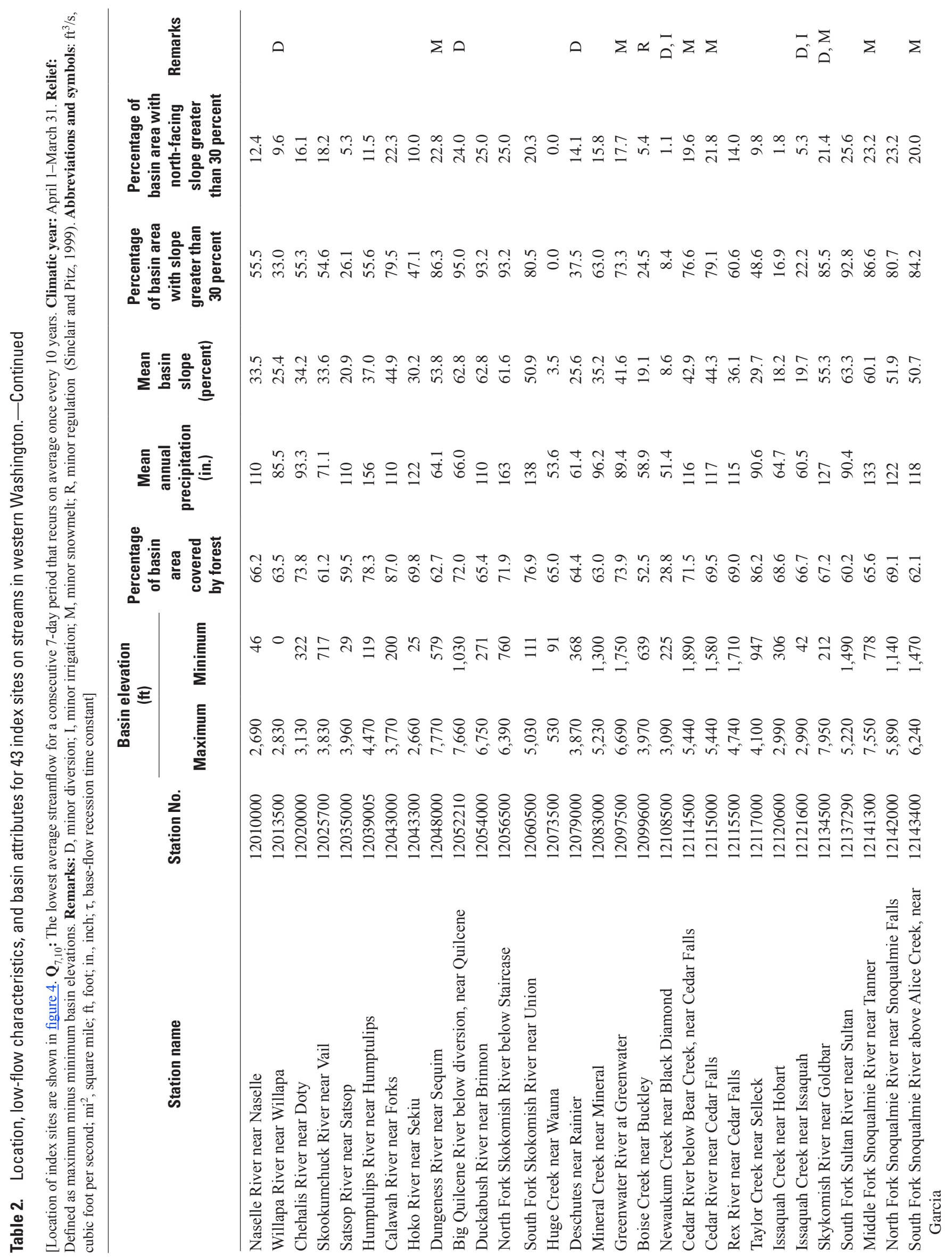




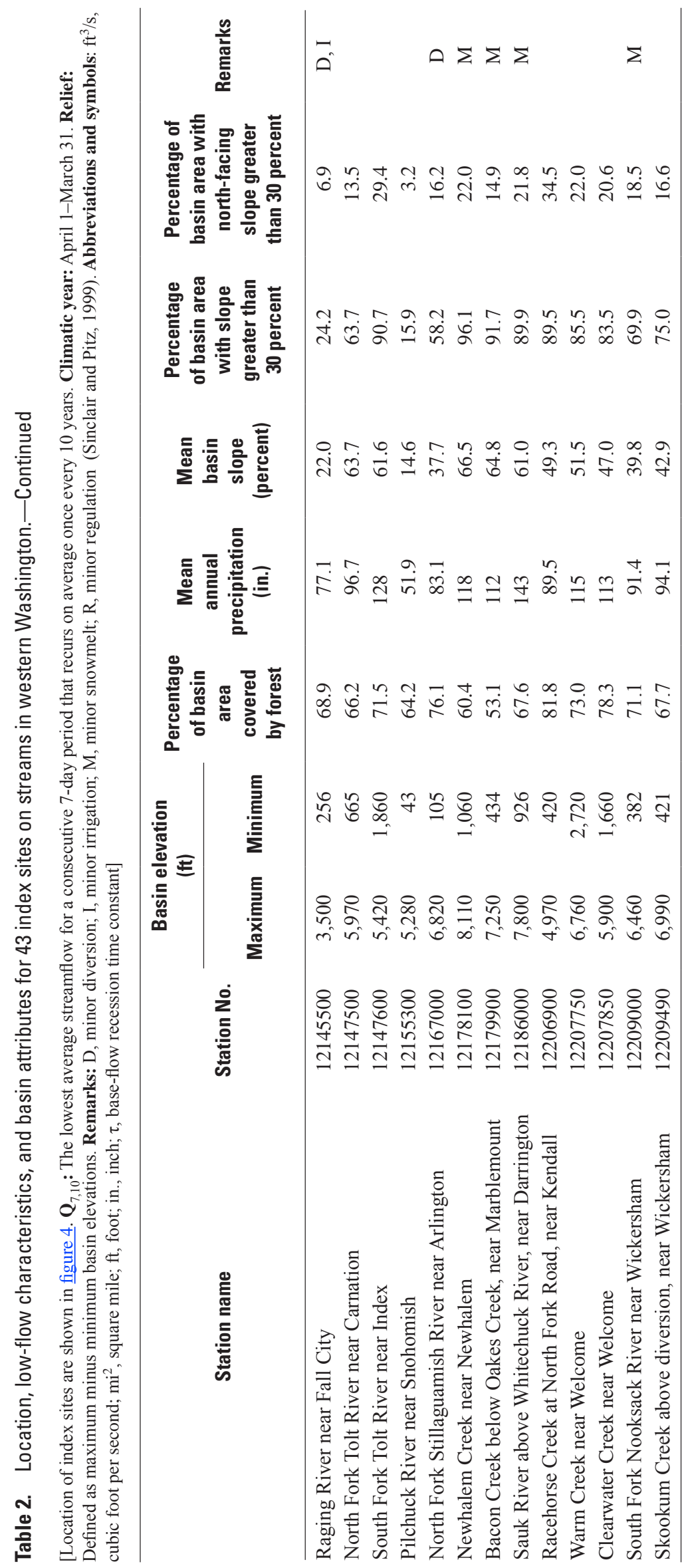




\section{Low-Flow Characteristics}

Low-flows in streams can be characterized in many ways. Typically, low-flow in a stream is assessed in terms of a minimum 7-day average of streamflow (the 7-day low-flow) in a climatic year (April 1-March 31), rather than a water year (October 1-September 30), to ensure the continuity of data during typical low-flow periods (which commonly occur in late summer). The annual series of 7-day low flows (determined for sites with continuous daily streamflow records) is used to calculate the probability that the 7-day low flow in any year will be less than a specified value (also referred to as the probability of non-exceedance). Tasker (1987) recommends using a 3-parameter, Log-Pearson Type III distribution to represent the annual series of 7-day low flows, in which the mean, variance, and skew of the distribution are computed from the annual series (fig. 2). Although $\mathrm{Q}_{7,10}$ is used in this report to characterize low flows in streams, the analytical methods could be applied to alternative low-flow characteristics. For example, alternative descriptors of low flow include the probability of zero flow (Bent and Steeves,
2006; Hortness, 2006), the magnitude of streamflow at critical times of the year (Hamilton and others, 2008), or the duration of continuous low-flow periods (Konrad and others, 2008). Cumulative distribution functions of daily streamflow (flowduration curves) are useful for characterizing the range of streamflows at a site and quantifying the percentage of flows that exceed specific low flows of interest (Searcy, 1959).

Values of $\mathrm{Q}_{7,10}$ for this study were initially computed using software developed by the USGS (Ken Eng, U.S. Geological Survey, written commun., 2007) that incorporates a conditional probability adjustment to account for streamflow records that may contain zero-flow events. Results of analyses made with this program were subsequently verified with a standard USGS statistical program (SWSTAT, version 4.1). Low-flow frequency and duration statistics can be readily computed using publicly available software provided and supported by the U.S. Environmental Protection Agency (2011; BASINS 4.0) that retrieves USGS streamflow data from the National Water Information System (U.S. Geological Survey, 2011a) and performs the necessary computations.

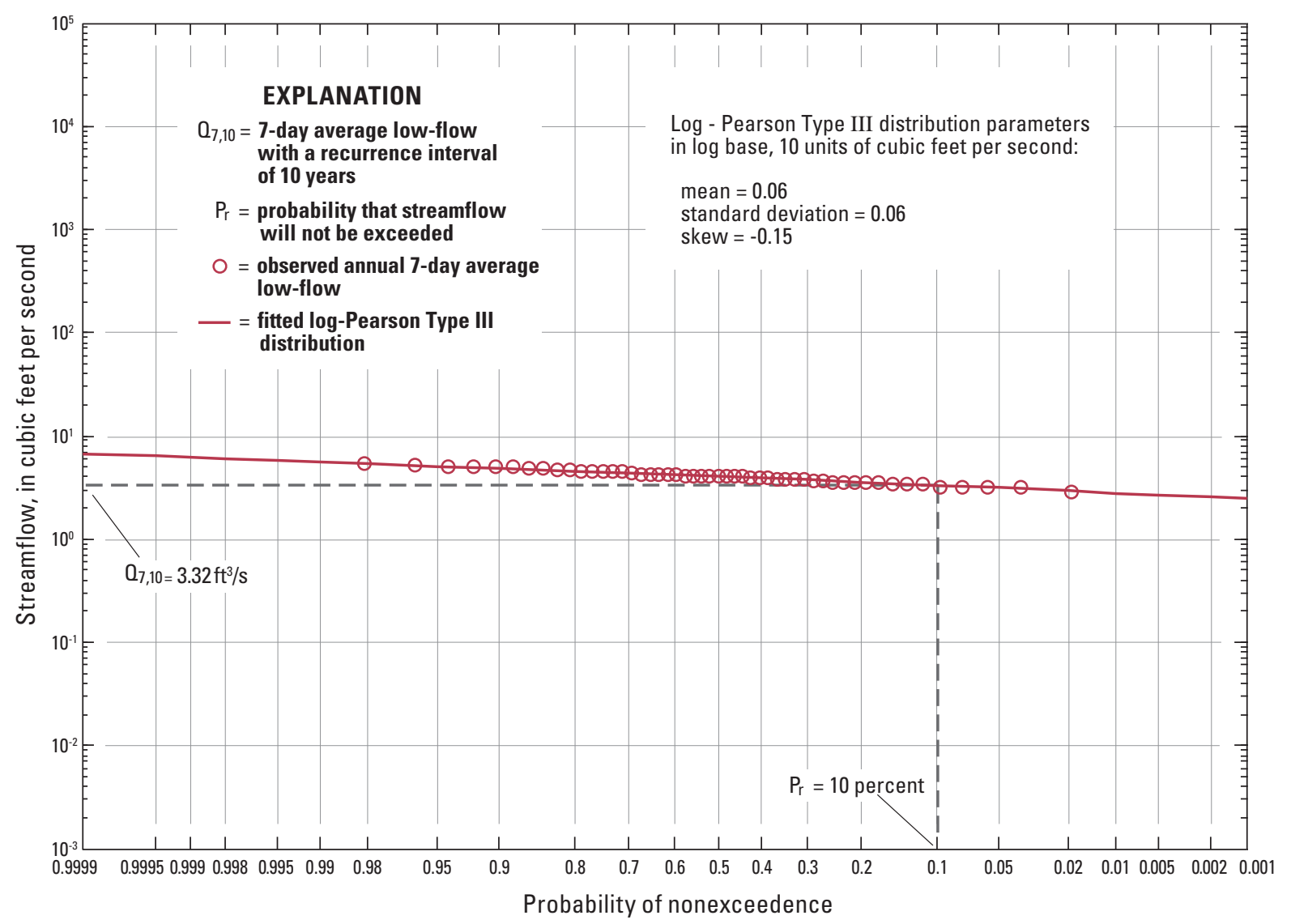

Figure 2. Example of the annual series of 7-day low flows fitted to the log-Pearson type III distribution for the calculation of $\mathrm{Q}_{7,10}$, computed from the streamflow record at the streamflow-gaging station Huge Creek near Wauna, Washington (U.S. Geological Survey station No. 12073500), 1947-69 and 1977-2007. 


\section{Base-Flow Recession Time Constant, or Tau $(\tau)$}

The rate of base-flow recession is an important lowflow characteristic in streams that is controlled by basin hydrogeology and the time since the last runoff event. Particularly after prolonged drought, the base-flow recession rate reveals the dependence of streamflow on groundwater inflow to the channel. Streams that are supported by relatively large inflows of groundwater generally will have slower rates of base-flow recession than streams that are hydraulically disconnected from, or lose water to, the groundwater system. The base-flow recession rate can be characterized as a single parameter referred to as the base-flow recession time constant, or tau $(\tau)$, and expressed as:

$$
\tau=\Delta t / \ln \left(Q_{0} / Q_{t}\right),
$$

where $\tau$ is the base-flow recession time constant (in days), $\Delta t$ is the time between observations (in days), and $Q_{0}$ and $Q_{t}$ (in units of volume per time) are values of streamflow at two points in time during a period of continuously decreasing streamflow (Eng and Milly, 2007). Thus, the value of $\tau$ can be readily estimated from two measurements of streamflow during the same low-flow period without intervening storms
(Eng and Milly, 2007). It should be noted, however, that such estimates of $\tau$ at partial-record sites may have substantial error due to the small number of observations, and may reflect inherent seasonality effects (for example, evapotranspiration) in some base-flow recessions (Brutsaert and Nieber, 1977).

Generally, the rate of base-flow recession can be expected to be rapid ( $\tau$ is small) in small basins with steep hillslopes, shallow soils, high drainage density, and aquifers with low transmissivity. Streamflow in such basins is sensitive to precipitation events; therefore, low-flow measurements should be made during periods without precipitation or snowmelt to ensure accurate estimates of low-flow characteristics. In contrast, the rate of base-flow recession can be expected to be slow ( $\tau$ is large) in large, gently sloping basins with deep soils, low drainage density, highly transmissive aquifers, and lakes. Estimates of low-flow characteristics are less sensitive to the timing of measurements in such streams because low flows are relatively stable. Examples of streams with small and large values of $\tau$ in western Washington are Racehorse Creek and the Satsop River, respectively (fig. 3). Eng and Milly (2007) introduced $\tau$ as a potential explanatory variable for regional low-flow regression models, and Funkhouser and others (2008) used kriging methods to regionalize $\tau$ for interpolation at ungaged sites.

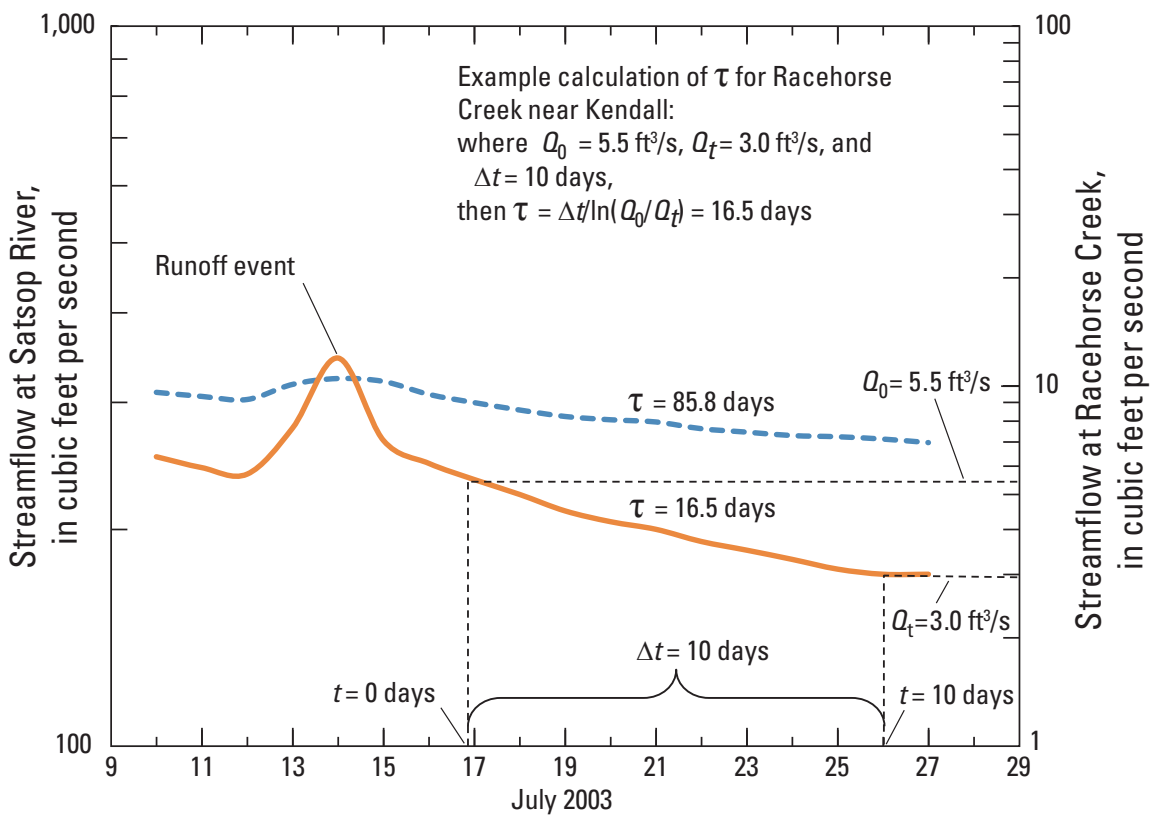

Figure 3. Base-flow hydrographs and corresponding values of $\tau$ calculated from a single period of base-flow recession at two U.S. Geological Survey streamflow-gaging stations in western Washington, Satsop River near Satsop, 12035000 (large $\tau$ ) and Racehorse Creek near Kendall, 12206900 (small $\tau$ ).

\section{EXPLANATION}

- - - Satsop River near Satsop (12035000)

Racehorse Creek near Kendall (12206900)

$\tau=$ Base-flow recession time constant, in days

$\Delta_{t}=$ Duration of baseflow recession period, in days

$\mathrm{O}_{0}=$ Streamflow at $t=0$ days

$Q_{t}=$ Streamflow at $t=10$ days 


\section{Low-Flow Surveys}

Technical staff from the Port Gamble S'Klallam, Hoh, Squaxin Island, Tulalip, Sauk-Suiattle, Nooksack, Puyallup, and Stillaguamish tribes and the PNPTC coordinated with the NWIFC and USGS to conduct low-flow measurements in streams across western Washington during the late summer and early autumn in 2007, 2008, and 2009. The measurement sites were selected by tribal and agency staff on the basis of several criteria, including the importance of the resource, accessibility, whether a site had been monitored for other purposes (for example, assessment of water quality), and whether a site represented combinations of basin attributes not represented by existing stream gages in western Washington. Sites with large diversions or return flows upstream of the stream gage, sites influenced by meltwater from snowfields or glaciers, and sites at which the stream was likely to go dry for extended periods during the low-flow season $\left(\mathrm{Q}_{7,10}=0 \mathrm{ft}^{3} / \mathrm{s}\right)$ were avoided. Although most watersheds in the study area have been affected to some extent by land-use changes (deforestation, urban development), land use does not appear to have a significant effect on dry-season base flow in either urban streams of western Washington (Konrad and Booth, 2005) or forested coastal watersheds in the northwest (Harris, 1977). The sites at which flow was measured during the 2007-09 low-flow surveys have basin areas ranging from 0.06 to $48.9 \mathrm{mi}^{2}$ (fig. 4 ).
The overall strategy for the low-flow surveys was to make repeated measurements of flow at selected sites to allow estimation of low-flow characteristics and incorporation of the sites into the regional analysis as partial-record stations. In the event that multiple measurements could not be made at a site, the individual measurements made under low-flow conditions would still provide information that could be used to track low-flow conditions over time and to evaluate errors in estimates of low flows from regression analyses. The USGS conducted training prior to the surveys to ensure that hydrologic technicians were familiar with standard techniques for streamflow measurement (Rantz, 1982).

The measurements were made by technical staff from NWIFC-member tribes, the PNPTC, and NWIFC from late July through September in 2007, 2008, and 2009, and by USGS personnel in 2007 (fig. 5). Measurements were made at least 3 days after measurable rainfall that caused an increase in runoff. When possible, pairs of measurements separated by at least 7 days were made during a period of continuous baseflow recession to allow calculation of $\tau$ (eq. 1). Documentation of measurements included a listing of the meter type and an assessment of measurement quality. At about one-third of the sites, initial measurements were repeated for verification of results and consistency in measurement procedures. 


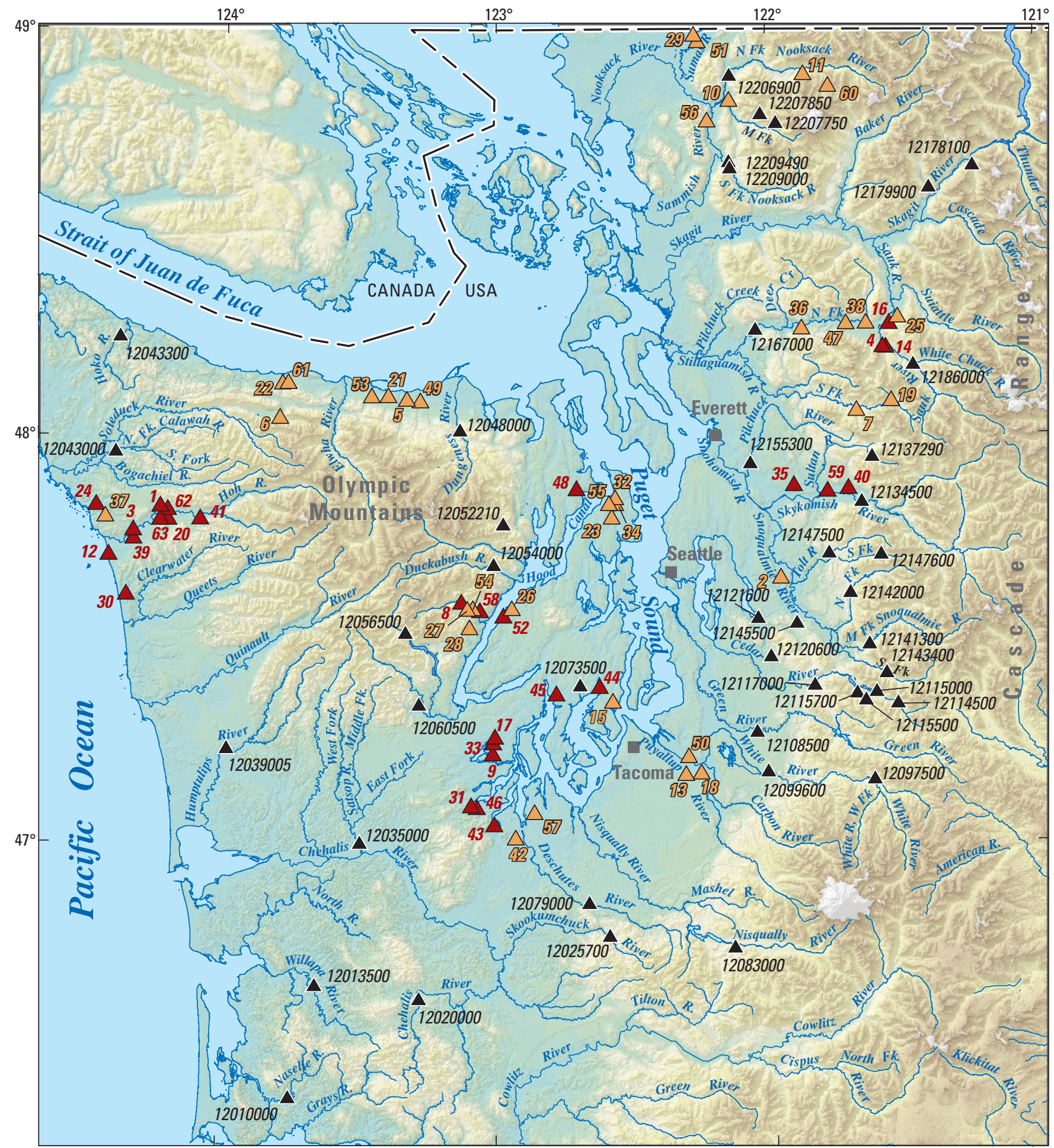

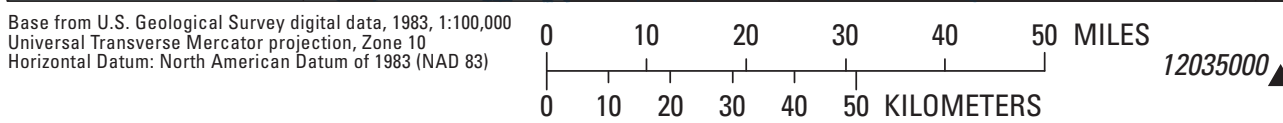

Figure 4. Locations of 63 partial-record and miscellaneous sites at which low-flow measurements were made by the Northwest Indian Fisheries Commission (NWIFC), NWIFC-member tribes, Point-No-Point Treaty Council, and the U.S. Geological Survey (USGS) from 2007 to 2009, and 43 USGS continuous streamflow-gaging stations (index sites) in western Washington.

\section{EXPLANATION}

Index site with USGS gaging station No. defined in table 2

43 Partial-record site with stream No. defined in table 7

482 $\triangle$ Miscellaneous site with stream No. defined in table 7 

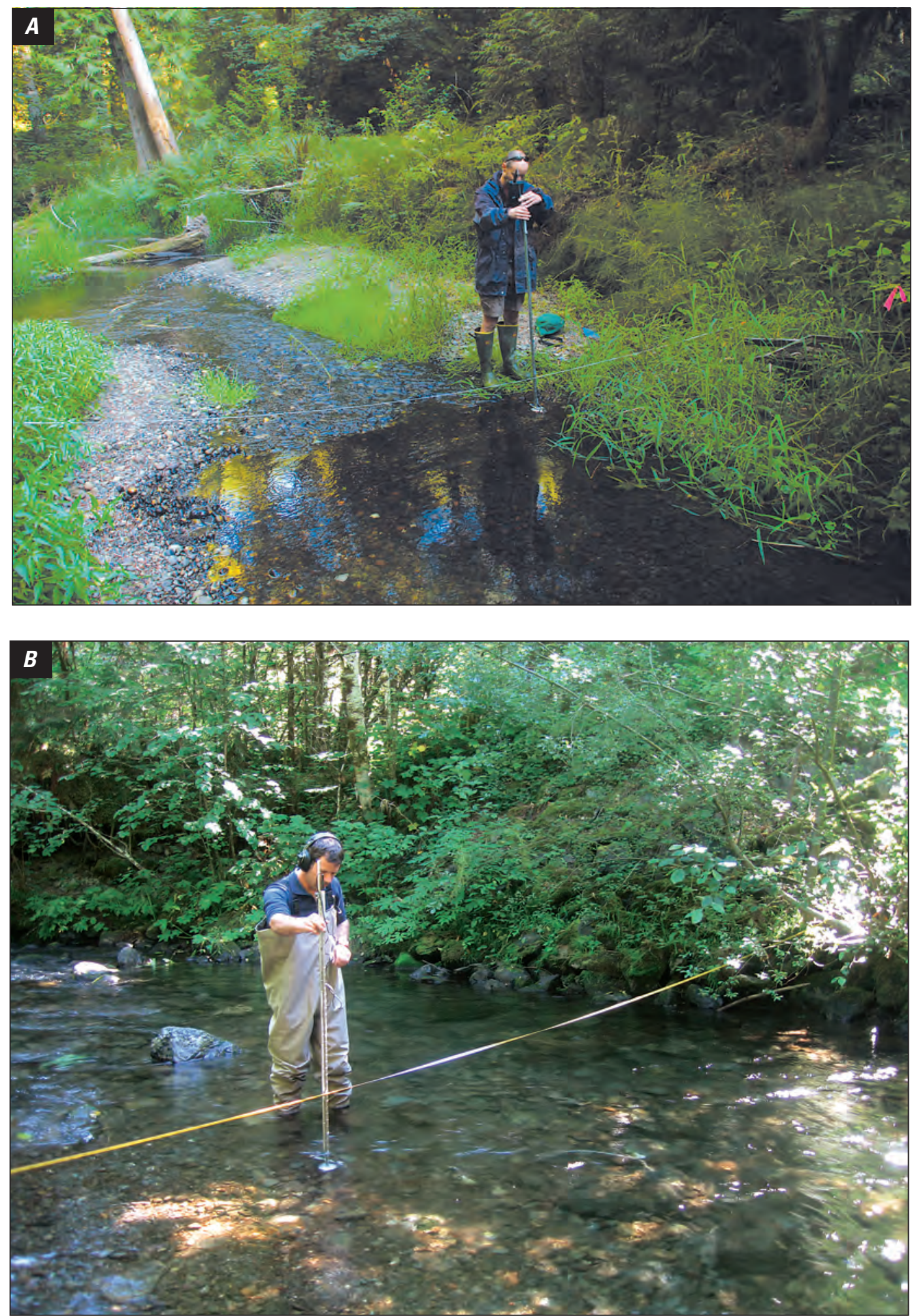

Figure 5. Examples of streamflow measurements made during the 2007-09 low-flow surveys of western Washington streams: $(A)$ Squaxin Tribe technical staff measures flow on Schneider Creek, Thurston County, Washington, and $(B)$ Point-No-Point Treaty Council technical staff measures flow on Thomas Creek, Kitsap County, Washington. 


\section{Estimating Low-Flow Characteristics at Partial- Record Streamflow-Measurement Sites}

Low-flow characteristics such as the $\mathrm{Q}_{7,10}$ at partialrecord sites are commonly estimated by using one of several index-site correlation methods, all of which require concurrent streamflow observations from a nearby or hydrologically similar index site. The index-site correlation methods most commonly used are: graphical, MOVE.1, and Base-Flow Correlation (U.S. Geological Survey, 1985). Although welldocumented in other regional low-flow studies (for example, Ries and Friesz, 2000; Funkhouser and others, 2008), for convenience these methods and an additional method, the Q-ratio method, are reviewed here with example calculations using results from the 2007-09 low-flow survey.

\section{Graphical Method}

First proposed by Riggs (1972), the graphical method is perhaps the easiest to use for estimating low-flow characteristics, but is also inherently biased (Stedinger and Thomas, 1985). This method may be appropriate when there is a non-linear relation between base-flow measurements at the partial record site and concurrent daily mean flows at the index site (U.S. Geological Survey, 1985). Riggs (1972) recommended that the graphical method be used with at least 8 to 10 base-flow measurements made on different recessions during 2 or more years. To use the method, concurrent observations of base flow are plotted, and a best-fit line is drawn through the observations and extended as needed to estimate the low-flow statistic of interest at the partialrecord site (fig. 6). When drawing the best-fit line, more weight should be given to lower base-flow observations (U.S. Geological Survey, 1985).

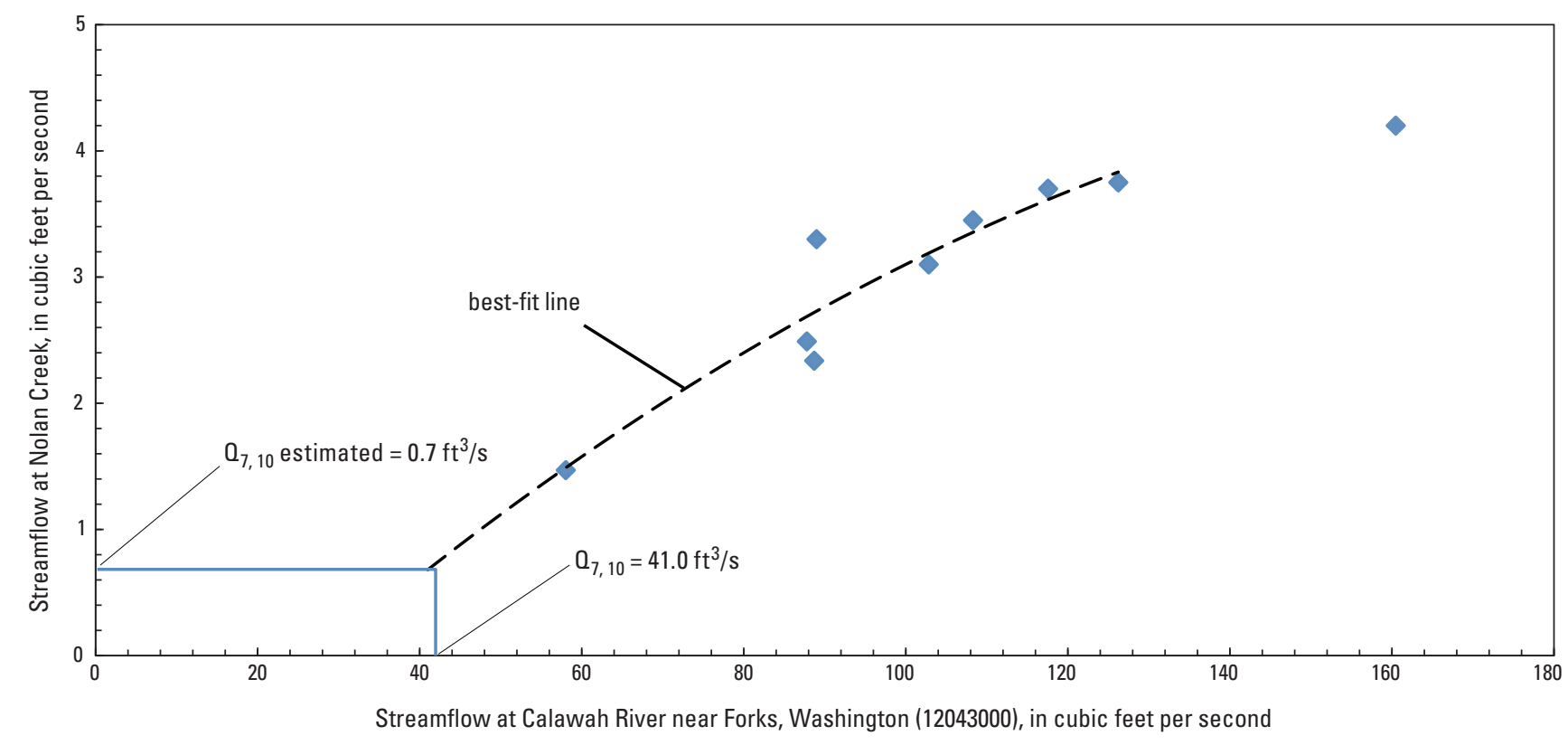

Figure 6. Example of graphical method used to estimate low-flow characteristics at a partial-record site (Nolan Creek, Jefferson County, Washington) from concurrent base flows at an index site (U.S. Geological Survey gaging station No.12043000, Calawah River near Forks, Washington) where the base-flow relation is non-linear. 


\section{Q-ratio Method}

A relatively simple, yet robust method developed by Potter (2001) and referred to here as the Q-ratio method, is generally recommended when the number of base-flow measurements at the partial-record site is small (fewer than eight measurements). In this method, concurrent flow pairs (streamflow measured at the partial-record site and streamflow recorded on the same day at the index site) are tabulated and the ratio of flows is determined for each pair. The average flow ratio is then calculated and multiplied by the flow statistic at the index site to estimate the statistic at the partial-record site. In equation form, the Q-ratio method is expressed as:

$$
Q_{p}=Z\left(Q_{i}\right)
$$

where $Q_{p}$ is the estimated low-flow statistic at the partialrecord site (in volume per time), $Z$ is the average flow ratio (dimensionless), and $Q_{i}$ is the low-flow statistic at the index site (in volume per time). The average flow ratio, $Z$, is calculated as

$$
Z=\frac{1}{N} \sum_{k=1}^{N}\left(\frac{Q_{p, k}}{Q_{i, k}}\right),
$$

where $N$ is the number of pairs of concurrent base-flow observations, $Q_{p, k}$ is the measured streamflow of the $k^{\text {th }}$ pair at the partial-record site, and $Q_{i, k}$ is the measured streamflow of the $k^{\text {th }}$ pair at the index site.

As an example, the Q-ratio method was used to estimate the $\mathrm{Q}_{7,10}$ for a partial-record site located on Cabin Creek in the Hamma Hamma River basin in Jefferson County, Washington. Four low-flow measurements were made at this site from 2007 to 2008 and are listed in table 3 with the concurrent flows from the USGS streamflow-gaging station at Huge Creek (12073500), which was selected as the index site on the basis of basin similarity (in terms of basin area, mean annual precipitation, $\tau$, and geographic proximity). Using equation 3 , $Z$ is calculated as the average ratio of the concurrent flow pairs $(Z=2.99)$. Then using equation 2 , the value of the $Q_{7,10}$ for Cabin Creek $\left(9.93 \mathrm{ft}^{3} / \mathrm{s}\right)$ is estimated by multiplying the $\mathrm{Q}_{7,10}$ for Huge Creek $\left(3.32 \mathrm{ft}^{3} / \mathrm{s}\right)$ by $Z$.

\section{MOVE.1 Method}

The Maintenance of Variance Extension, Type 1 (MOVE.1) method (Hirsch, 1982) is commonly used for extending the length or filling missing periods of the flow record at a continuously recording streamflow-gaging station. However, the method also can be used to estimate low-flow frequency or duration statistics at a partial-record site. Also
Table 3. Example of the use of the 0-ratio method to estimate low-flow characteristics at a partial-record site (Cabin Creek, Jefferson County, Washington) on the basis of concurrent low-flow characteristics at an index site (U.S. Geological Survey gaging station No. 12073500, Huge Creek near Wauna, Washington).

$\left[\mathbf{Q}_{\mathrm{p}, \mathrm{k}}:\right.$ The $k^{\text {th }}$ streamflow measured at the partial-record site. $\mathbf{Q}_{\mathrm{i}, \mathrm{k}}:$ The $k^{\text {th }}$ concurrent streamflow recorded at the index site. Q-ratio: The flow ratio equal to $Q_{p, k} / Q_{i, k}$ : : The average ratio of concurrent flow pairs. $\mathbf{Q}_{\mathrm{i}}$ : The value of the low-flow statistic $\left(Q_{7,10}\right)$ at the index site. $\mathbf{Q}_{\mathrm{p}}$ : The estimated value of the low-flow statistic $\left(\mathrm{Q}_{7,10}\right)$ at the partial-record site. Abbreviations: $\mathrm{ft}^{3} / \mathrm{s}$,

\begin{tabular}{|c|c|c|c|c|c|c|}
\hline Date & $\begin{array}{c}\mathbf{0}_{\mathrm{p}, \mathrm{k}} \\
\left(\mathrm{ft}^{3} / \mathrm{s}\right)\end{array}$ & $\begin{array}{c}\mathbf{0}_{\mathrm{i}, \mathrm{k}} \\
\left(\mathrm{ft}^{3} / \mathrm{s}\right)\end{array}$ & Q-ratio & Z & $\underset{\left(\mathrm{ft}^{3} / \mathrm{s}\right)}{\mathbf{a}_{\mathrm{i}}}$ & $\underset{\left(\mathrm{ft}^{3} / \mathrm{p}\right)}{\mathbf{p}_{\mathrm{s}}}$ \\
\hline \multicolumn{7}{|c|}{2007} \\
\hline 09-07 & 13.3 & 4.46 & 2.98 & - & - & - \\
\hline $09-20$ & 12.0 & 4.29 & 2.80 & - & - & - \\
\hline \multicolumn{7}{|c|}{2008} \\
\hline 09-11 & 12.2 & 3.86 & 3.16 & - & - & - \\
\hline 09-16 & 12.2 & 4.03 & 3.03 & - & - & - \\
\hline \multicolumn{7}{|c|}{ 2007-08 } \\
\hline- & - & - & - & 2.99 & - & - \\
\hline \multicolumn{7}{|c|}{ Period of record of index site } \\
\hline- & - & - & - & - & 3.32 & 9.93 \\
\hline
\end{tabular}
cubic foot per second; -, does not apply]

referred to as the line of organic correlation, MOVE. 1 is preferred over more common linear regression techniques, such as ordinary least squares, because it preserves the inherent variance of streamflow data at the partial-record site and results in an estimate of flow that is less biased. This method is recommended when eight or more base-flow measurements are available for a partial-record site and requires concurrent flows from a hydrologically similar index site. The MOVE.1 method follows the equation:

$$
\hat{Y}=\bar{Y}+\frac{s_{y}}{s_{x}}(\hat{X}-\bar{X})
$$

where $\hat{Y}$ is the estimated low-flow statistic (transformed to $\log$ units) at the partial-record site, $\bar{Y}$ is the average of the base-flow measurements (log units) at the partial-record site, $s_{y}$ and $s_{x}$ are the standard deviations of the log transformed base flows at the partial-record site and index site, respectively, $\underline{X}$ is the low-flow statistic (log units) at the index site, and $\bar{X}$ is the average of concurrent flows (log units) at the index site. Measurements of zero flow cannot be used as log transformations are required in this method. 
As an example, MOVE.1 was used to estimate the $\mathrm{Q}_{7,10}$ for a partial-record site on Winfield Creek in the Hoh River basin of Jefferson County, Washington. Ten low-flow measurements were made at this site from 2007 to 2009 (table 4) and are listed with concurrent flows at USGS streamflow-gaging station Calawah River (12043000), which was selected as the index site. All streamflow values are logtransformed (in this example, base-10 is used) and the mean values are calculated for Winfield Creek and Calawah River as $0.830(\bar{Y})$ and $2.02(\bar{X})$, respectively. Similarly, the standard deviations are calculated from the log-transformed streamflow values at each site as $0.129\left(s_{y}\right)$ and $0.161\left(s_{x}\right)$. The logtransformed $\mathrm{Q}_{7,10}$ for the Calawah River $(X)$ is $1.61\left(\mathrm{Q}_{7,10}\right.$ is $\left.41.0 \mathrm{ft}^{3} / \mathrm{s}\right)$ and, applying equation 4 , the log-transformed $\mathrm{Q}_{7,10}$ for Winfield Creek $(\hat{Y})$ is $0.502\left(\mathrm{Q}_{7,10}\right.$ is $\left.3.18 \mathrm{ft}^{3} / \mathrm{s}\right)$.

Table 4. Example of the use of the MOVE.1 method to estimate the $0_{7,10}$ at a partial-record site (Winfield Creek, Jefferson County, Washington) from concurrent low flows at an index site (U.S. Geological Survey gaging station No. 12043000, Calawah River near Forks, Washington).

$\left[\mathbf{Y}_{k}\right.$ : The $k^{\text {th }}$ streamflow measured at the partial record site. $\mathbf{X}_{k}$ : The $k^{\text {th }}$ concurrent streamflow measured at the index site. $\mathbf{s}_{Y}$ and $\mathbf{s}_{X}$ : The standard deviations of log-transformed flows at the partial-record site and index-site, respectively. $\overline{\mathbf{Y}}$ and $\overline{\mathbf{X}}$ : The average of the log-transformed flows at the partial-record site and index site, respectively. $\mathbf{Q}_{i}$ : The $\mathrm{Q}_{7,10}$ at the index site. $\mathbf{X}$ : The $\log$-transformed value of the $\mathrm{Q}_{7,10}$ at the index site. $\mathbf{Y}$ : The logtransformed estimate of the $\mathrm{Q}_{7,10}$ at the partial-record site; $\mathbf{Q}_{p}$ : The estimate of $\mathrm{Q}_{7,10}$ at the partial-record site. Abbreviations: $\mathrm{ft}^{3} / \mathrm{s}$, cubic foot per second; -, does not apply]

\begin{tabular}{|c|c|c|c|c|c|c|c|c|c|c|c|c|}
\hline Date & $\begin{array}{c}Y_{k} \\
\left(\mathrm{ft}^{3} / \mathrm{s}\right)\end{array}$ & $\begin{array}{c}X_{k} \\
\left(\mathrm{ft}^{3} / \mathrm{s}\right)\end{array}$ & $\log _{10} Y_{k}$ & $\log _{10} X_{k}$ & $s_{Y}$ & $s_{X}$ & $\overline{\mathbf{Y}}$ & $\bar{x}$ & $\begin{array}{c}a_{i} \\
\left(\mathrm{ft}^{3} / \mathrm{s}\right)\end{array}$ & $\hat{x}$ & $\hat{\gamma}$ & $\begin{array}{c}Q_{p} \\
\left(\mathrm{ft}^{3} / \mathrm{s}\right)\end{array}$ \\
\hline \multicolumn{13}{|c|}{2007} \\
\hline 08-15 & 8.94 & 163 & 0.951 & 2.21 & - & - & - & - & - & - & - & - \\
\hline 09-07 & 7.37 & 126 & 0.867 & 2.10 & - & - & - & - & - & - & - & - \\
\hline 09-19 & 5.23 & 93.2 & 0.719 & 1.97 & - & - & - & - & - & - & - & - \\
\hline \multicolumn{13}{|c|}{2008} \\
\hline $07-11$ & 8.16 & 140 & 0.912 & 2.15 & - & - & - & - & - & - & - & - \\
\hline $07-23$ & 6.25 & 95.3 & 0.796 & 1.98 & - & - & - & - & - & - & - & - \\
\hline 08-07 & 6.39 & 85.2 & 0.806 & 1.93 & - & - & - & - & - & - & - & - \\
\hline 09-08 & 11.4 & 175 & 1.06 & 2.24 & - & - & - & - & - & - & - & - \\
\hline $09-17$ & 7.22 & 114 & 0.859 & 2.06 & - & - & - & - & - & - & - & - \\
\hline \multicolumn{13}{|c|}{2009} \\
\hline $07-21$ & 5.17 & 73.3 & 0.713 & 1.87 & - & - & - & - & - & - & - & - \\
\hline 08-03 & 4.15 & 52.1 & 0.618 & 1.72 & - & - & - & - & - & - & - & - \\
\hline \multicolumn{13}{|c|}{ 2007-09 } \\
\hline- & - & - & - & - & 0.129 & 0.161 & 0.830 & 2.02 & - & - & - & - \\
\hline \multicolumn{13}{|c|}{ Period of record of index site } \\
\hline- & - & - & - & - & - & - & - & - & 41.0 & 1.61 & 0.502 & 3.18 \\
\hline
\end{tabular}




\section{Base-Flow Correlation Method}

The Base-Flow Correlation method (Stedinger and Thomas, 1985) was developed as an un-biased technique for estimating low-flow frequency statistics at partial-record sites. The method assumes a Log-Pearson Type III distribution for the annual time series of d-day low flows (for example, the consecutive 7-day low flow, or $\mathrm{Q}_{7}$ ) at the partial-record sites and index sites, and an equal skew coefficient for the distribution of $\mathrm{Q}_{7}$ at both sites. For reliable results, a minimum of 10 base-flow measurements at a partial-record site is recommended when using this method (U.S. Geological Survey, 1985). An estimate of the $Q_{7}$ with a recurrence interval of 10 years $\left(\hat{Q}_{7,10}\right)$ is calculated for a partial-record site using the Base-Flow Correlation method

$$
\log _{10}\left(\hat{Q}_{7,10}\right)=\hat{\mu}_{p}+K_{p} \hat{\sigma}_{p}
$$

where $\hat{\mu}_{p}$ is the estimated mean of the annual $Q_{7}$ at the partialrecord site, $K_{p}$ is the log-Pearson Type III standard deviate for a recurrence interval of 10 years, and $\hat{\sigma}_{p}$ is the estimated standard deviation of the annual $Q_{7}$ time series at the partialrecord site. To estimate $\hat{\mu}_{p}$ and $\hat{\sigma}_{p}$, a simple linear regression between the log-transformed concurrent flows at the partialrecord site and index site is performed to obtain the regression coefficients $\beta_{1}$ (slope) and $\beta_{0}$ (intercept). These coefficients are further used to estimate $\hat{\mu}_{p}$ and $\hat{\sigma}_{p}$ as follows:

$$
\hat{\mu}_{p}=\beta_{0}+\beta_{1} m_{i}
$$

and

$$
\hat{\sigma}_{p}=\sqrt{\beta_{1}^{2} s_{i}^{2}+s_{e}^{2}\left[1-\frac{s_{i}^{2}}{(n-1) s_{c}^{2}}\right]},
$$

where $m_{i}$ and $s_{i}^{2}$ are the mean and variance of the annual $\mathrm{Q}_{7}$ time series at the index site, $s_{c}^{2}$ is the variance of the concurrent flows at the index site, $n$ is the number of concurrent base-flow measurement pairs, and $s_{e}^{2}$ is the square of the standard error of the regression among log-transformed concurrent flows at the partial-record site and index site.
The standard deviate for the partial-record site, $K_{p}$, is assumed equal to the standard deviate for the index site, $K_{i}$, and, if not already known, is calculated as

$$
K_{i}=\frac{\log _{10}\left(Q_{7,10}\right)-m_{i}}{s_{i}},
$$

where $Q_{7,10}$ is known at the index site, $m_{i}$ is described previously, and $s_{i}$ is the standard deviation of the $Q_{7}$ time series at the index site.

As an example, the Base-Flow Correlation Method was used to estimate the $\mathrm{Q}_{7,10}$ for a partial-record site on Dan Creek in Snohomish County, Washington, where 10 lowflow measurements were made from 2007 to 2009; data and derived coefficients are shown in table 5 . Concurrent, daily mean flows were obtained from an index site with similar basin attributes, in this case, South Fork Sultan River near Sultan, Washington (USGS gaging station No. 12137290). A least-squares regression equation was developed with the log-transformed, concurrent flows at the partial-record and index sites, and the intercept and slope of the regression were computed. The time series of annual 7-day low flows $\left(\mathrm{Q}_{7}\right)$ was determined at the index site for the period of record, the values were log-transformed, and the mean was calculated. In this example, the known value of $\mathrm{Q}_{7,10}$ for the index site is $6.34 \mathrm{ft}^{3} / \mathrm{s}$ based on 14 years of continuous streamflow record, and the estimated $\mathrm{Q}_{7,10}$ for the partial-record site Dan Creek is calculated as $1.80 \mathrm{ft}^{3} / \mathrm{s}$. 


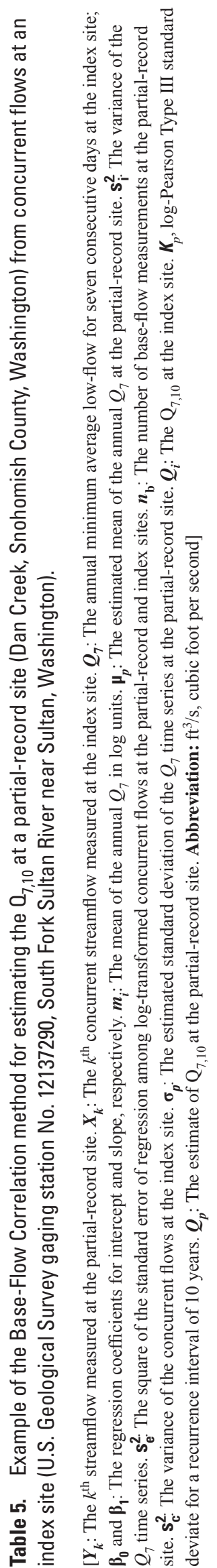

\begin{tabular}{|c|c|c|c|c|c|c|c|c|c|c|c|c|c|c|c|c|c|c|c|c|}
\hline $\begin{array}{l}\sigma^{2} \\
\text { 음 }\end{array}$ & & & & & & & & & & & & & & & & & & & & 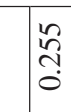 \\
\hline$\sigma^{2} \overline{\underline{\underline{p}}}$ & & & & & & & & & & & & & & & & & & & & نه \\
\hline$z$ & & & & & & & & & & & & & & & & & & & & ભુ \\
\hline 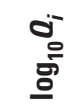 & & & & & & & & & & & & & & & & & & & & $\begin{array}{c}\tilde{\sigma} \\
\stackrel{\alpha}{0} \\
\stackrel{0}{0}\end{array}$ \\
\hline$\sigma^{-\frac{\bar{m}}{\underline{p}}}$ & & & & & & & & & & & & & & & & & & & & స్ \\
\hline $0^{2}$ & & & & & & & & & & & & & & & & & & & & 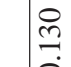 \\
\hline$x^{\circ}$ & & & & & & & & & & & & & & & & & & & & בิ \\
\hline$=$ & & & & & & & & & & & & & & & & & & & & 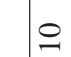 \\
\hline$x^{\circ}$ & & & & & & & & & & & & & & & & & & & & $\vec{\sigma}$ \\
\hline$i_{5}^{-1}$ & & & & & & & & & & & & & & & & & & & & 吾 \\
\hline$=$ & & & & & & & & & & & & & & & & & & & & 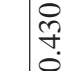 \\
\hline 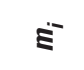 & & & & & & & & & & & & & & & & & & & & 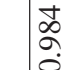 \\
\hline$=$ & & & & & & & & & & & & & & & & & & & & $\begin{array}{l}\tilde{N} \\
0 \\
0\end{array}$ \\
\hline$\cong$ & & & & & & & & & & & & & & & & & & & & 离 \\
\hline $\begin{array}{l}\text { ó } \\
\text { 음 }\end{array}$ & & & & & & & & & & 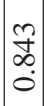 & 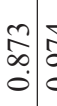 & to & $\stackrel{\Xi}{-}$ & & 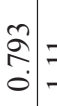 & 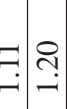 & $\stackrel{9}{-}$ & 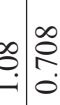 & 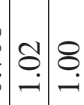 & \\
\hline$\sigma^{-\bar{a}}$ & & & & & & & & & & â. & 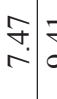 & 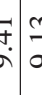 & $\stackrel{\circ}{\exists}$ & $\begin{array}{l}0 \\
\dot{\exists} \\
-1\end{array}$ & 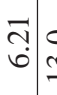 & 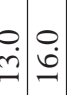 & $\stackrel{0}{\underset{\sim}{\sim}}$ & 억 & $\stackrel{0}{\bullet} \stackrel{0}{\ominus}:$ & \\
\hline 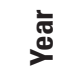 & & & & & & & & & & ปี & $\begin{array}{l}\mathscr{\sigma} \\
\mathscr{\sigma}\end{array}$ & 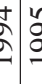 & \& & $\hat{\sigma}$ & $\begin{array}{l}\infty \\
\stackrel{2}{2} \\
\stackrel{్}{2}\end{array}$ & ¿. & ¿े & 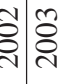 & ㅎํㅇㅇㅠ & \\
\hline $\begin{array}{l}\text { ×- } \\
\text { 흫 }\end{array}$ & $\stackrel{\mathscr{f}}{\rightarrow}$ & - & 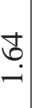 & | & ma & f & 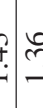 & $\stackrel{\square}{\vec{m}}$ & F & & & & & & & & & & & \\
\hline 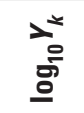 & $\begin{array}{l}\vec{\pi} \\
\text { రै. } \\
0\end{array}$ & 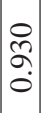 & $\begin{array}{l}0 \\
\frac{1}{0} \\
0\end{array}$ & . & อ. & 7 & $\left\{\begin{array}{l}0 \\
0 \\
0 \\
0\end{array}\right.$ & ì & 勇 & & & & & & & & & & & \\
\hline$x=\frac{\bar{\infty}}{\underline{\underline{p}}}$ & $\stackrel{\sim}{\sim}$ & $\left|\begin{array}{l}0 \\
\dot{0} \\
\dot{0}\end{array}\right|$ & $\begin{array}{l}\dot{v} \\
\dot{q}\end{array}$ & : & 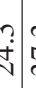 & ç & $\dot{\vec{l}} \overrightarrow{\mathrm{s}}$ & $\infty$ & Lึ & & & & & & & & & & & \\
\hline$\lambda=\underline{\underline{\underline{\underline{\rho}}}}$ & $\stackrel{\stackrel{\sim}{~}}{+}$ & 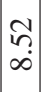 & $\begin{array}{l}\text { ते } \\
\text { ì }\end{array}$ & ڤ. & f & பு & 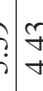 & 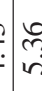 & \& & & & & & & & & & & & \\
\hline 营 & $\begin{array}{l}\text { o } \\
\text { ते } \\
\text { के } \\
0\end{array}$ & \begin{tabular}{|l|}
$\infty$ \\
0 \\
1 \\
1 \\
$o$ \\
0 \\
0 \\
0
\end{tabular} & 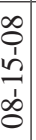 & ô & 芳 & d) & $\begin{array}{l}\text { co } \\
\text { s. }\end{array}$ & $\begin{array}{l}0 \\
1 \\
1\end{array}$ & $\frac{0}{1}$ & & & & & & & & & & & \\
\hline
\end{tabular}




\section{Empirical Monte Carlo Technique for Evaluating Index-Site Correlation Methods}

The performance of three index-site correlation methods (Q-ratio, MOVE.1, Base-Flow Correlation) and the optimal number of base-flow measurements to use for each method was evaluated using an empirical Monte Carlo technique in MATLAB computing software (The MathWorks Inc., 2008). Required inputs for the program are the daily streamflow data for a user-defined number of index sites, and the lowflow characteristic (such as the $\mathrm{Q}_{7,10}$ ) and basin attributes for each site. The program identifies base-flow recession segments of the hydrograph for all index sites, subject to user-defined criteria such as the hydrologic season, minimum duration of recession segments, minimum streamflow that defines a peak, and the number of days since the peak to begin recession segments. In the analysis, index sites are sequentially simulated as partial-record sites (hereafter referred to as 'synthetic partial-record sites'), wherein a userdefined number of observations (daily streamflow values from the continuous record) are randomly selected from recession segments. These observations are then paired with concurrent streamflows at an index site and the $\mathrm{Q}_{7,10}$ (or other low-flow statistic) is estimated using the methods of Q-ratio, MOVE.1, and Base-Flow Correlation. The index site used for correlating concurrent flows is selected from the pool of other sites on the basis of basin attribute similarity. The sequence of randomly selecting concurrent streamflows (within user-defined constraints) is repeated 500 times, and with each iteration an estimate of $\mathrm{Q}_{7,10}$ is generated for each index site using the three correlation methods. Residual error is then determined for each correlation method by comparing the estimated $\mathrm{Q}_{7,10}$ with the value determined from the streamflow record. The average error and bias associated with estimating the $Q_{7,10}$ at each synthetic partial-record site are computed for each correlation method under scenarios that differ in the number of observations and the combination of basin attributes used to select an index site.

In addition to evaluating correlation methods to estimate $\mathrm{Q}_{7,10}$ values, the MATLAB program also calculated the baseflow recession time constant, $\tau$, at each index site (Eng and Milly, 2007). The calculation of $\tau$ was performed as part of the empirical Monte Carlo analysis for each index site using a number of observation pairs (ranging from 2 to 10) defined by the user for each scenario. Discharge observation pairs were selected along randomly selected base-flow recession segments, and equation 1 was used to calculate $\tau$. Because the value of $\tau$ is based on only a few observations, a more robust estimate, $\tau_{\text {ideal }}$, was calculated for each index site based on 500 observation pairs from randomly selected recession segments. The values of $\tau$ calculated from 2 to 10 observation pairs for each index site were compared with $\tau_{\text {ideal }}$ to determine the optimum number of streamflow measurements required to reliably estimate $\tau$ at partial-record sites.

\section{Basin-Attribute Selection}

Fifteen basin attributes were considered for the purposes of index-site selection within the Monte Carlo analysis as well as for serving as explanatory variables in preliminary regional low-flow regressions. Basin attributes were selected to represent physical and climatic parameters in the region that might explain observed variations in base flow. Basin attributes are shown in table 6. The USGS Washington StreamStats program (U.S. Geological Survey, 2010) was used to delineate basin areas and determine 10 of the 15 basin attributes for all of the index sites. Four basin attributes pertaining to surficial geology were determined from simplified geologic maps of the Puget Sound and Pacific Coast sub-regions (Jones, 1999). Geographic proximity was determined from the locations (latitude and longitude) of index sites, and the base-flow recession time constant $(\tau)$ was determined from the empirical Monte Carlo program, as previously described. Variables were screened for multi-collinearity, and where strong correlations were found between variables (for example, mean annual precipitation and mean basin elevation), only one variable was retained for further analysis. The five variables considered in the final empirical Monte Carlo analysis were: basin area (A), mean annual precipitation $(\mathrm{P})$, geographic proximity (G), percentage of basin area covered with surficial geology classified as 'coarse-grained unconsolidated sediments' (S), and $\tau$.

\section{Index-Site Selection}

An index site that would be used for correlating with each synthetic partial-record site was selected within the empirical Monte Carlo analysis on the basis of basin similarity. To quantify basin similarity, the Euclidean distance (measured in basin-attribute values) was calculated between the synthetic partial-record site and all index sites considered in the analysis. The index site with the minimum Euclidean distance relative to the synthetic partial-record site was considered closest in basin similarity and thus selected for use in further analysis.

The Euclidean distance was calculated as:

$R_{i j}=\sum_{k=1}^{N}\left(\frac{\left(\log X_{1, i}-\log X_{1, j}\right)^{2}}{\sigma_{k}^{2}\left(\log X_{1}\right)}+\ldots+\frac{\left(\log X_{k, i}-\log X_{k, j}\right)^{2}}{\sigma_{k}^{2}\left(\log X_{k}\right)}\right)$

where $R_{i j}$ is the Euclidean distance (dimensionless), $i$ is the partial-record site, $j$ is the index-site, $N$ is the number of basin attributes, $X_{k, i}$ is the value of the $k^{\text {th }}$ basin attribute for the partial-record site, $X_{k, j}$ is the value of the $k^{\text {th }}$ basin attribute for the index site, and $\sigma_{k}^{2}$ is the variance of the log-transformed values of the $k^{\text {th }}$ basin attribute for all potential index sites considered (Eng and others, 2009). 
Table 6. Basin attributes and data sources used for index-site selection in the empirical Monte Carlo analysis and for developing preliminary regional low-flow regressions for western Washington.

[Data source: 1, U.S. Geological Survey, Washington StreamStats; 2, U.S. Weather Bureau, 1965; 3, Vaccaro and others, 1998; 4, National Elevation Dataset (NED) http://seamless.usgs.gov/ned1.php; 5, This report. Abbreviation: NAD 83, North American Datum of 1983]

\begin{tabular}{|c|c|c|}
\hline Basin attribute & Description & Data source \\
\hline Latitude & Latitude/Longitude, NAD 83 & 1 \\
\hline Basin area & Drainage area, in square miles & 1 \\
\hline Precipitation & Mean annual precipitation (1930-57), in inches & 1,2 \\
\hline Relief & Relief (maximum minus minimum basin elevation), in feet & 1,4 \\
\hline Elevation & Mean basin elevation, in feet & 1,4 \\
\hline Elevation, maximum & Maximum basin elevation, in feet & 1,4 \\
\hline Elevation, minimum & Minimum basin elevation, in feet & 1,4 \\
\hline Slope & Mean basin slope, in percent & 1,4 \\
\hline Slope, greater than 30 percent & Percentage of basin area with slope greater than 30 percent & 1,4 \\
\hline Slope, greater than 30 percent facing north & Percentage of basin area with slope greater than 30 percent and facing north & 1,4 \\
\hline Bedrock & Percentage of basin area with surficial geology classified as bedrock & 3 \\
\hline Fine grain & $\begin{array}{l}\text { Percentage of basin area with surficial geology classified as fine-grained } \\
\text { unconsolidated sediments }\end{array}$ & 3 \\
\hline Coarse grain & $\begin{array}{l}\text { Percentage of basin area with surficial geology classified as coarse-grained } \\
\text { unconsolidated sediments }\end{array}$ & 3 \\
\hline Alluvial & $\begin{array}{l}\text { Percentage of basin area with surficial geology classified as alluvial } \\
\text { sediments }\end{array}$ & 3 \\
\hline $\operatorname{Tau}(\tau)$ & Base-flow recession time constant, in days & 5 \\
\hline
\end{tabular}

\section{Results of Analysis of Low Flow in Western Washington Streams}

In western Washington, the mean monthly streamflow at the 43 index sites used in this study is generally lowest from July through September (fig. 7). The annual minimum streamflow generally occurs during this period, with the specific date depending on summer storm patterns and the long-term base-flow recession associated with decreasing aquifer discharge to the stream in the late spring and early summer. Annual minimum streamflows are relatively stable from year to year, and range from about 70 to 130 percent of the median value at most gaging stations. On a unitarea basis, annual minimum streamflow ranges from 0.2 to $2\left(\mathrm{ft}^{3} / \mathrm{s}\right) / \mathrm{mi}^{2}$ for the period of record at index sites, with a median of about $0.7\left(\mathrm{ft}^{3} / \mathrm{s}\right) / \mathrm{mi}^{2}$. Streamflow at the index sites for the July-September period was about average in 2007 , above average in 2008, and generally below average in 2009 (fig. 8). Streamflows exceeded about 90 percent of the time are roughly equivalent to the median 7-day low flow at index sites (fig. 9). Likewise, streamflows exceeded about 99 percent of the time are roughly equivalent to the $\mathrm{Q}_{7,10}$. 


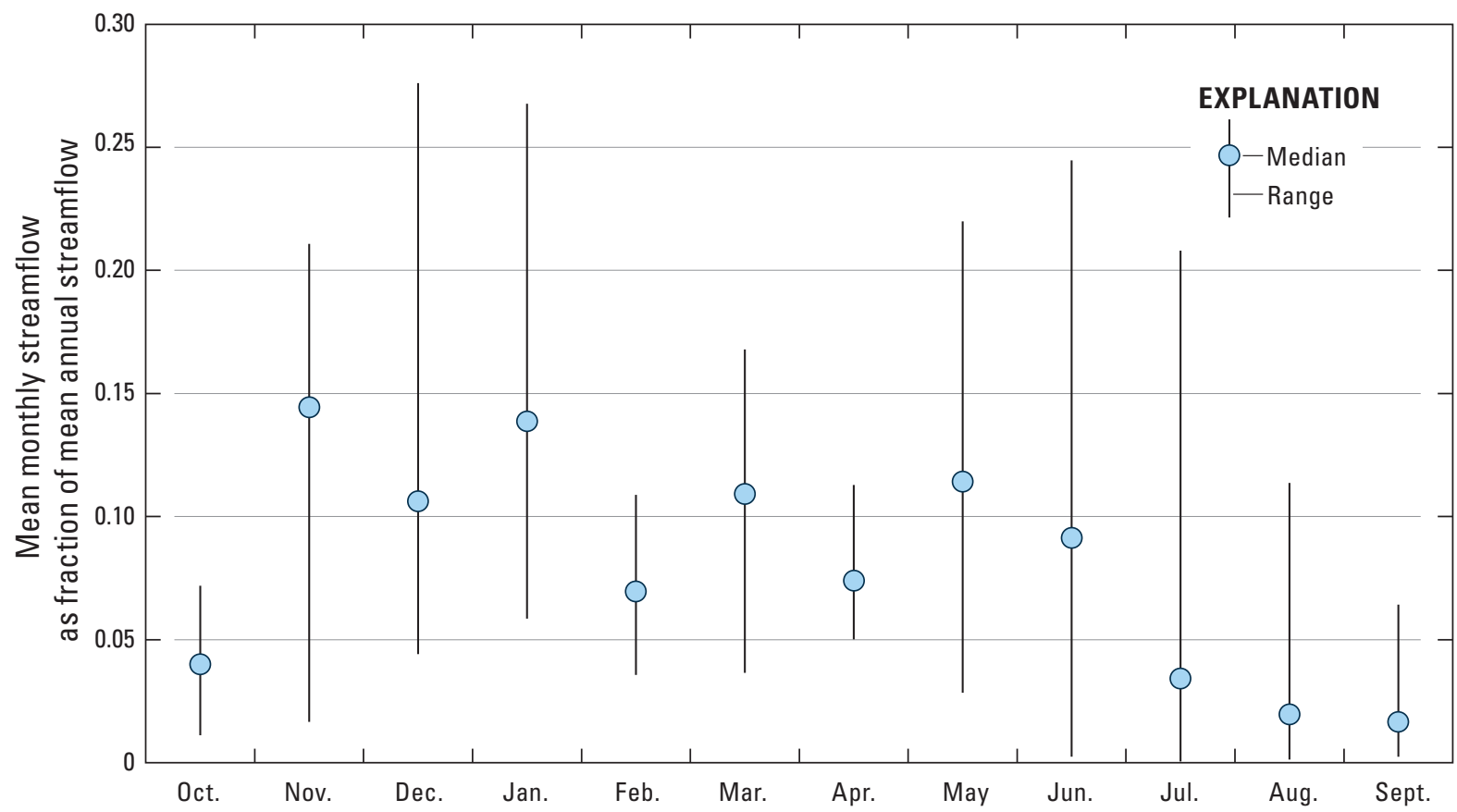

Figure 7. Range of mean monthly streamflow as a fraction of mean annual streamflow for the period of record at 43 index sites in western Washington.

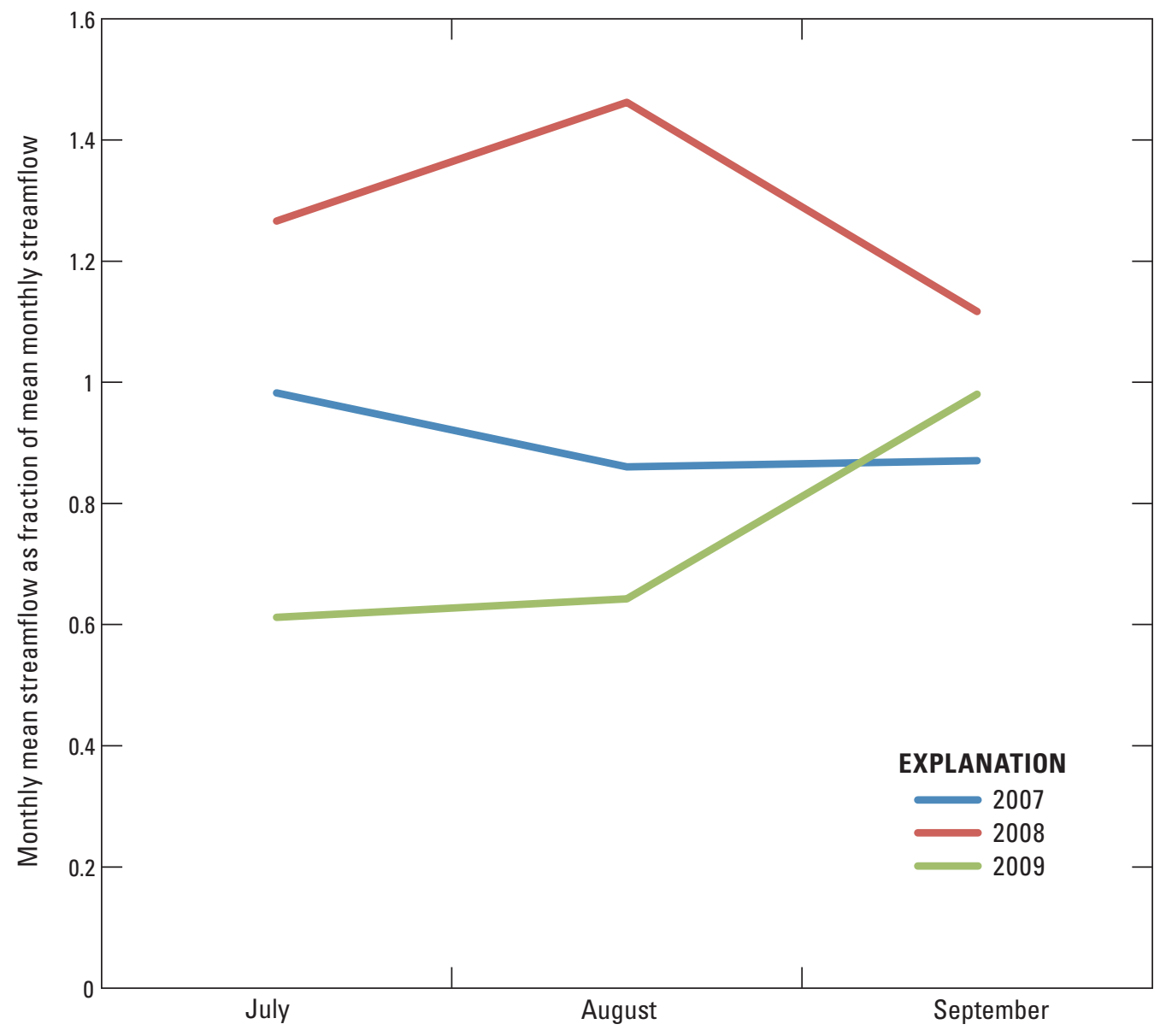

Figure 8. Monthly mean streamflow during July-September in 2007-09 as a fraction of mean monthly streamflow for the period of record at 43 index sites in western Washington. 

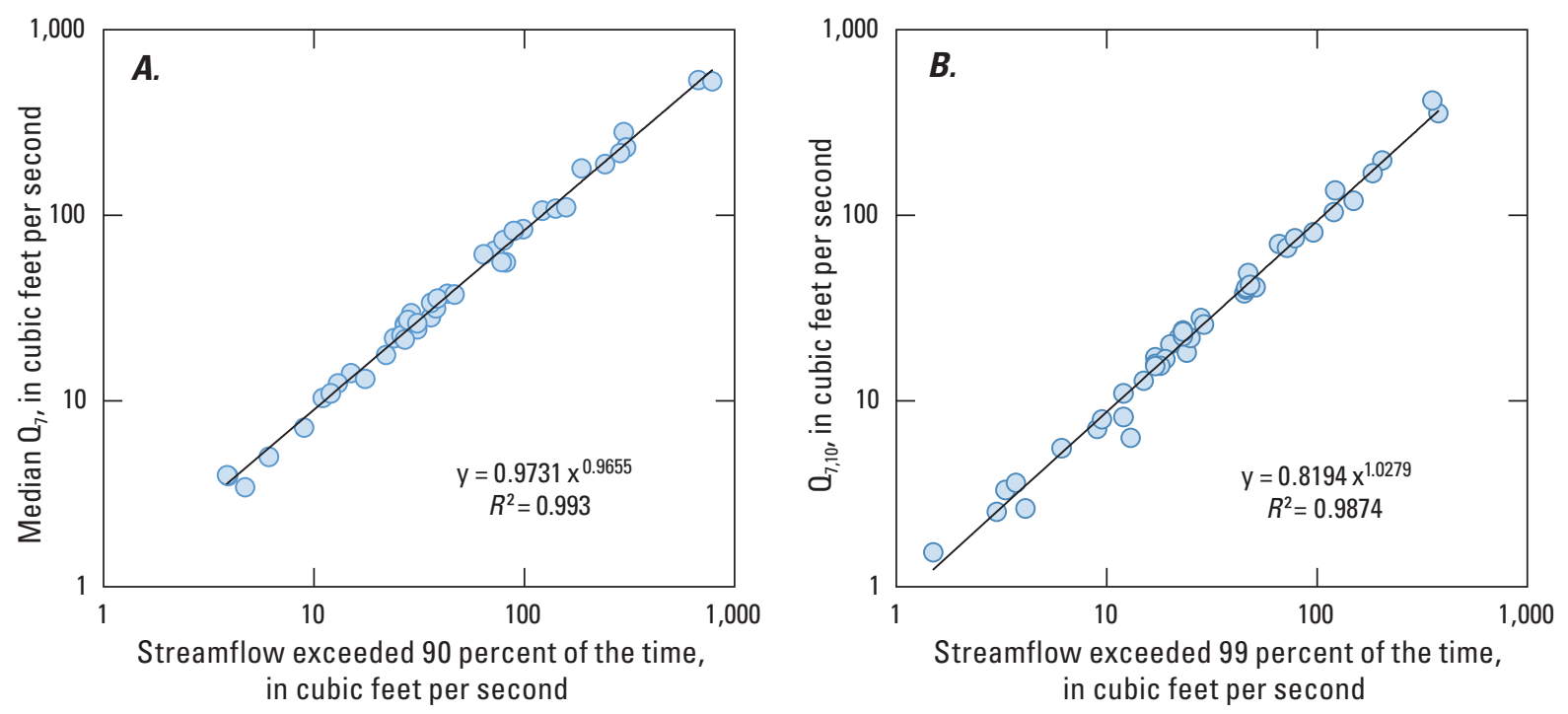

Figure 9. Streamflows at 43 index sites $(A)$ median 7-day low flow $\left(Q_{7}\right)$ versus streamflow exceeded 90 percent of the time, and $(B)$ lowest average 7 -day low flow that recurs on average every 10 years $\left(0_{7,10}\right)$ versus streamflow exceeded 99 percent of the time.

\section{Low-Flow Surveys in 2007, 2008, and 2009}

Flow was measured at 63 stream sites on 66 days in 2007, 2008, and 2009. Of the 283 measurements made, 42 were duplicate verification measurements. The number of measurements made at each stream ranged from 1 to 10. Pairs of measurements were made at 25 sites during the same base-flow recession period for estimating $\tau$. Because rainfall varies across the region and is often of only local extent during summer, measurements were made on different days at different sites. The median unit-area flow of all measurements was $0.5\left(\mathrm{ft}^{3} / \mathrm{s}\right) / \mathrm{mi}^{2}$, with a range from 0.06 to $16\left(\mathrm{ft}^{3} / \mathrm{s}\right) / \mathrm{mi}^{2}$. The $\mathrm{Q}_{7,10}$ was estimated using the Q-ratio method for miscellaneous sites and for partial-record sites with fewer than eight measurements. The MOVE.1 method was used for partial-record sites if eight or more measurements were made and concurrent flow pairs were reasonably well correlated (Pearson's r greater than or equal to 0.65 ); otherwise, the Q-ratio method was used. Index sites were selected on the basis of basin similarity, using the variables basin area (A), geographic proximity $(\mathrm{G})$, mean annual precipitation $(\mathrm{P})$, and $\tau$ (if known), and the minimum Euclidean distance determined from equation 9. All partial-record and miscellaneous sites where flow was measured during the low-flow surveys are listed in table 7, and the measurements and ancillary information are tabulated in appendix A. Basin attributes were determined for all partial-record and miscellaneous sites using the Washington StreamStats program (U.S. Geological Survey, 2010) and are listed in table 8.

The basin attributes for the partial-record and miscellaneous sites established during the low-flow surveys are not well represented in the existing streamflow-gagingstation network in western Washington. These sites are generally in smaller drainage areas (than sites in the existing network) that generate less runoff and have correspondingly lower values of $\mathrm{Q}_{7,10}$ (fig. 10). The incorporation of these sites into the existing streamflow-gaging network will enable development of regional regression models that more accurately estimate low-flow characteristics at these types of ungaged stream sites. 


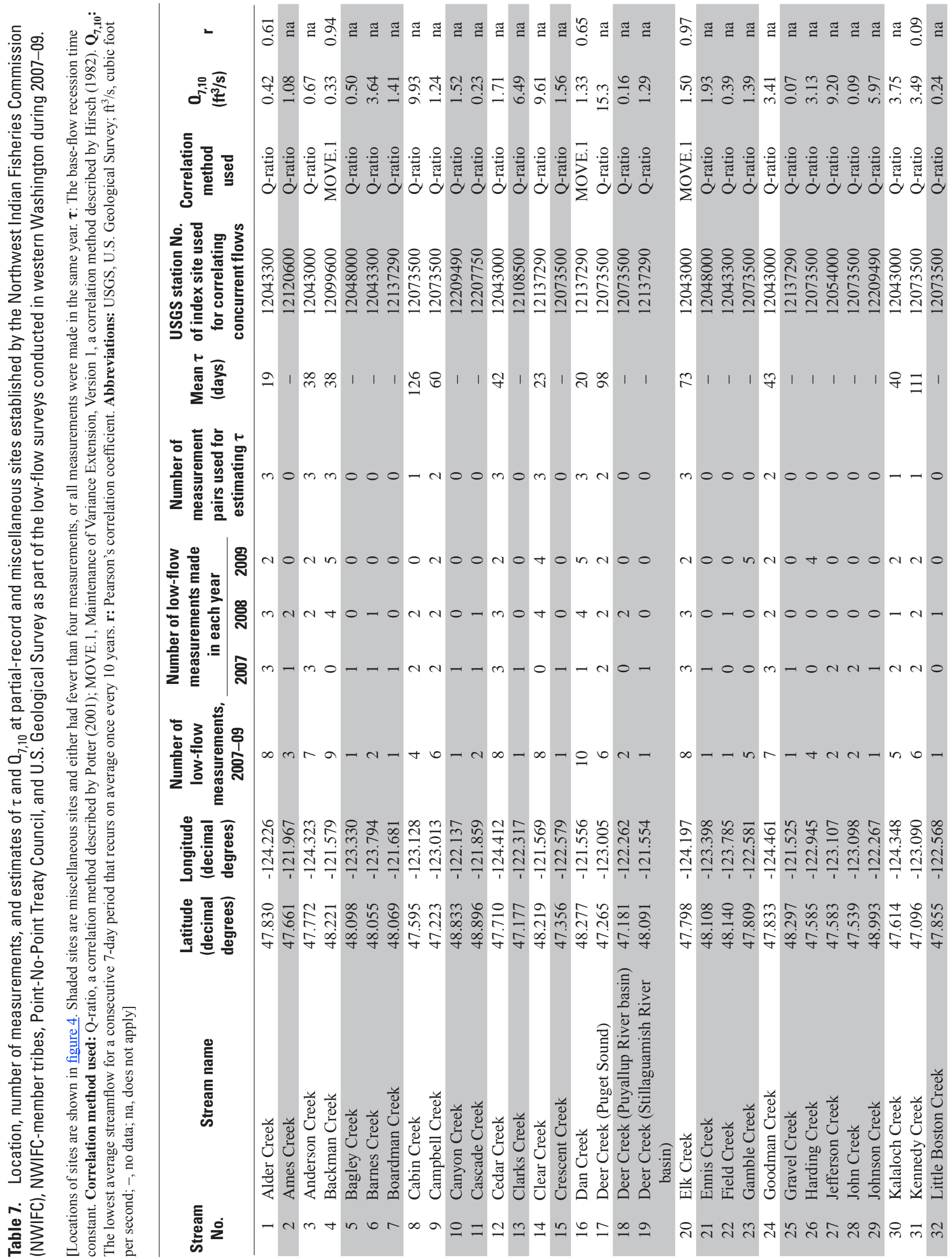




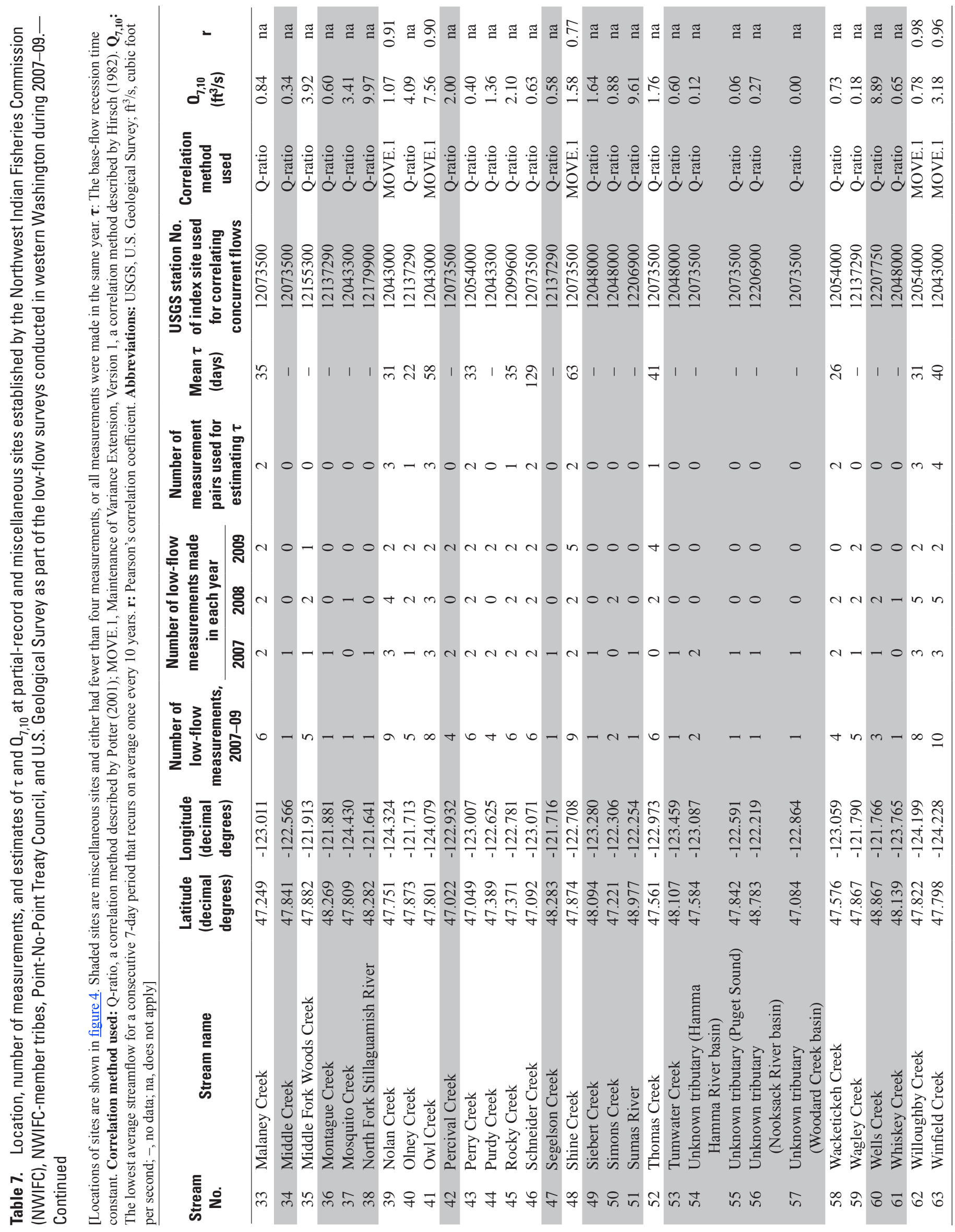




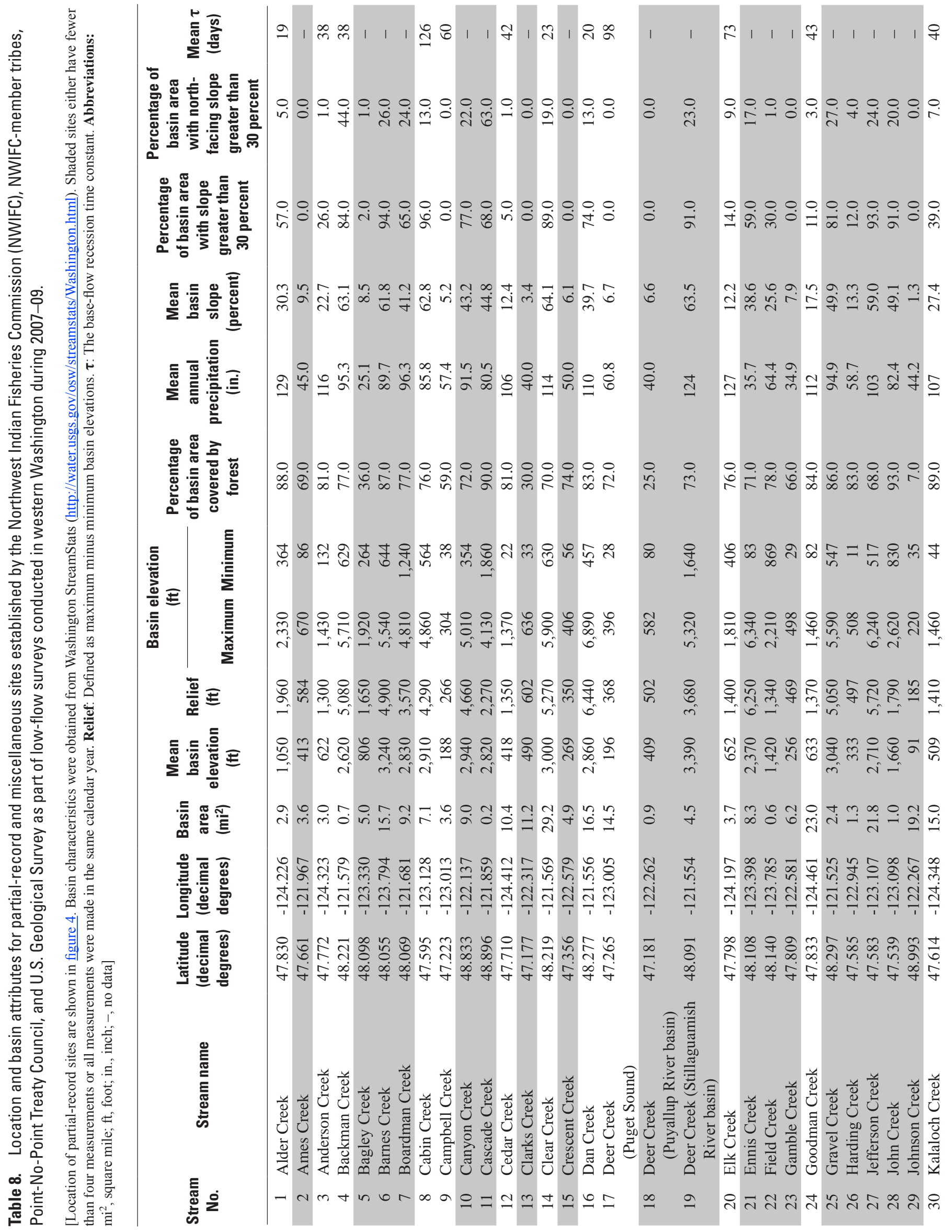




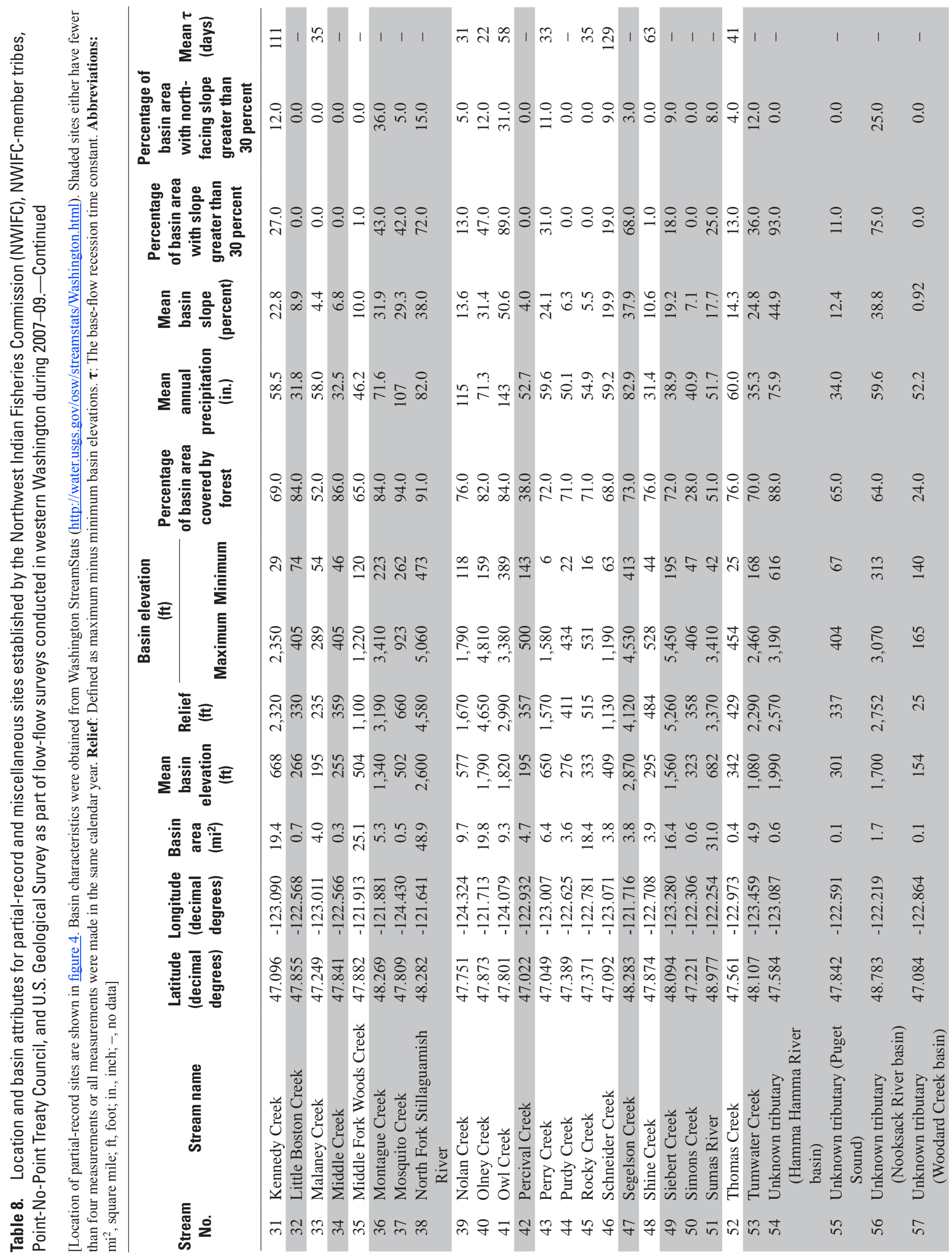




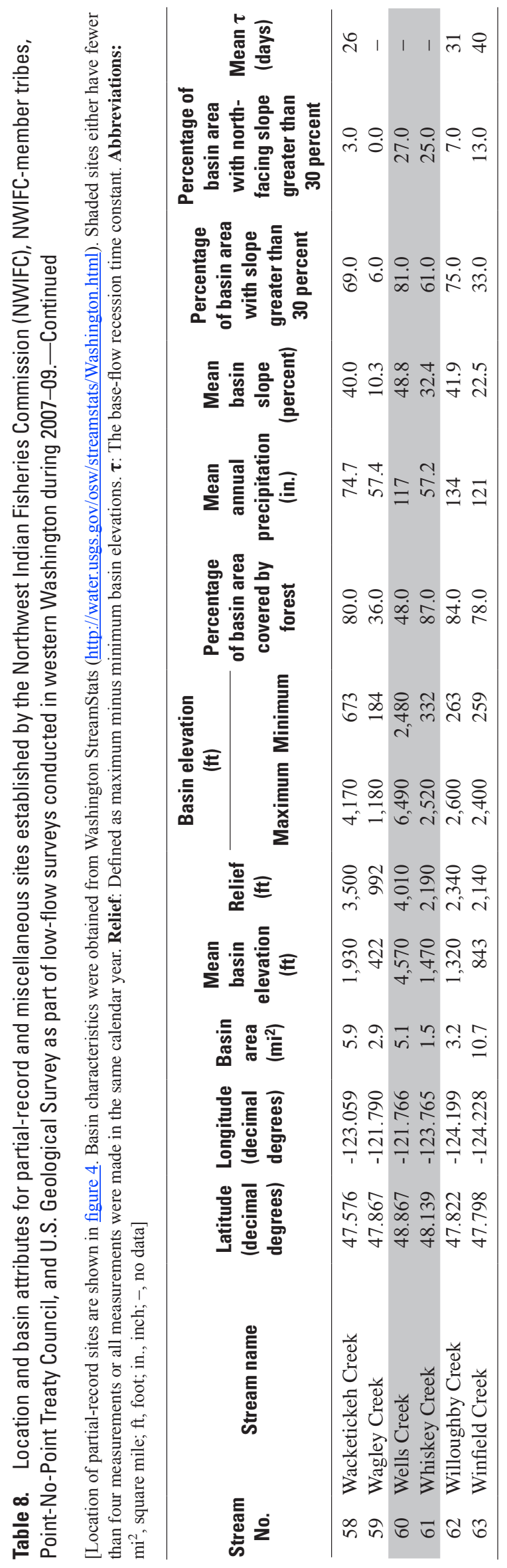




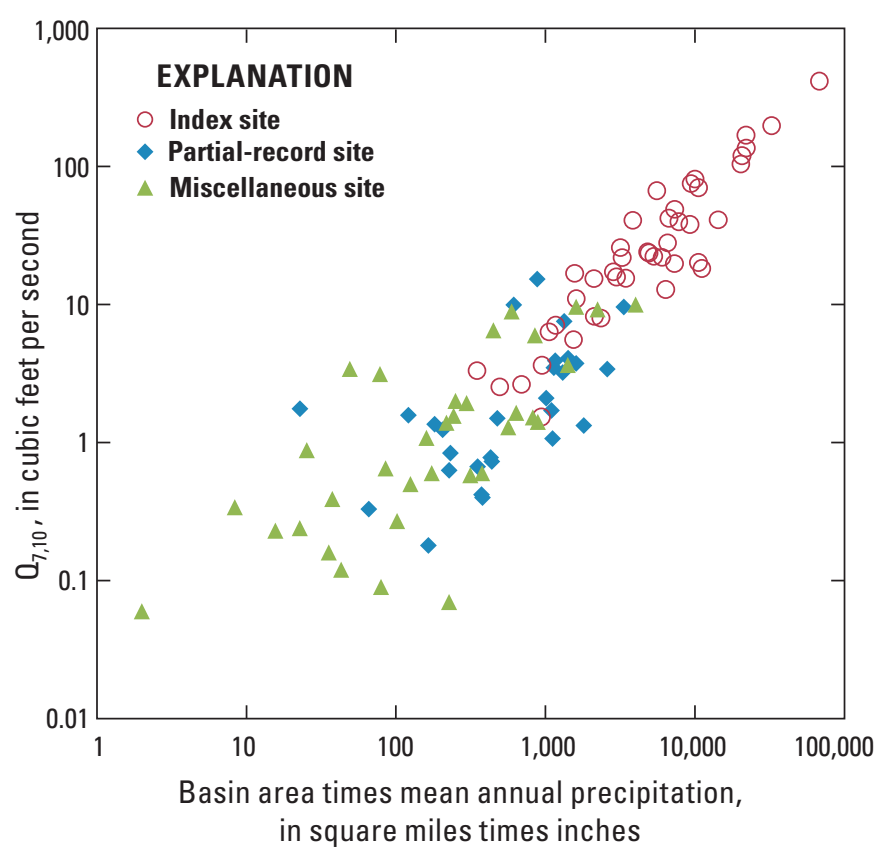

Figure 10. Relation between low-flow characteristics $\left(0_{7,10}\right)$ and selected basin attributes (basin area times mean annual precipitation) of index, partial-record, and miscellaneous sites in western Washington.

\section{Empirical Monte Carlo Analysis}

The $\mathrm{Q}_{7,10}$ was estimated at 43 synthetic partial-record sites (defined in section Empirical Monte Carlo Technique for Evaluating Index-Site Correlation Methods) using each of the three correlation methods (Q-ratio, MOVE.1, and BaseFlow Correlation) in 170 scenarios. Each of these scenarios is defined by the number of streamflow observations (ranging from 4 to 20) or observation pairs (ranging from 2 to 10), and the combination of basin attributes used to select an index site. For example, in one scenario the $\mathrm{Q}_{7,10}$ was estimated at each of the 43 synthetic partial-record sites on the basis of only four flow measurements, and the index site was selected based on similarity in the basin attributes of basin area (A), mean annual precipitation (P), and geographic proximity (G). For another scenario, three pairs of observations (each pair from the same base-flow recession segment) and only the basin attribute $\tau$ were used in the analysis. To allow the calculation of $\tau$ as a basin attribute, half of the scenarios contain streamflow observation pairs $\left(Q_{0}\right.$ and $Q_{t}$, separated by $t$ number of days; see equation 1 ) from the same randomly selected base-flow recession segment.

In all scenarios, the root-mean square error (RMSE) expressed as a percentage is calculated from the difference between the estimated $\mathrm{Q}_{7,10}$ value (derived from the average of 500 repeated applications of the Q-ratio, MOVE.1, and Base-Flow Correlation methods) and the $\mathrm{Q}_{7,10}$ value calculated from the continuous daily record at each of the 43 index sites. Generally, as the number of concurrent streamflow observation increases, the RMSE decreases for the MOVE. 1 and BaseFlow Correlation methods, but changes comparatively little for the Q-ratio method (fig. 11). Of the three correlation methods, Q-ratio results in the smallest RMSE for almost all scenarios. The optimum number of observations for the Q-ratio method is four, with only slight reductions in the RMSE with additional observations.

The overall bias (defined herein as the estimated value minus the true value) for each correlation method was calculated as the arithmetic average of the bias for all estimates of $\mathrm{Q}_{7,10}$ in a given scenario (fig. 12). The correlation method with the largest absolute bias for each scenario generally was Base-Flow Correlation, whereas the method with the smallest absolute bias was Q-ratio. Additionally, the bias for the MOVE.1 and Base-Flow Correlation methods was consistently positive (estimates of $\mathrm{Q}_{7,10}$ were greater than true values), whereas the Q-ratio method had a consistently negative bias (estimates of $\mathrm{Q}_{7,10}$ were less than true values). In estimating low-flow statistics, methods that have smaller bias are preferred, but the preferred direction of bias (and hence the definition of a conservative estimate) depends on how the estimated flow statistic will be used. 


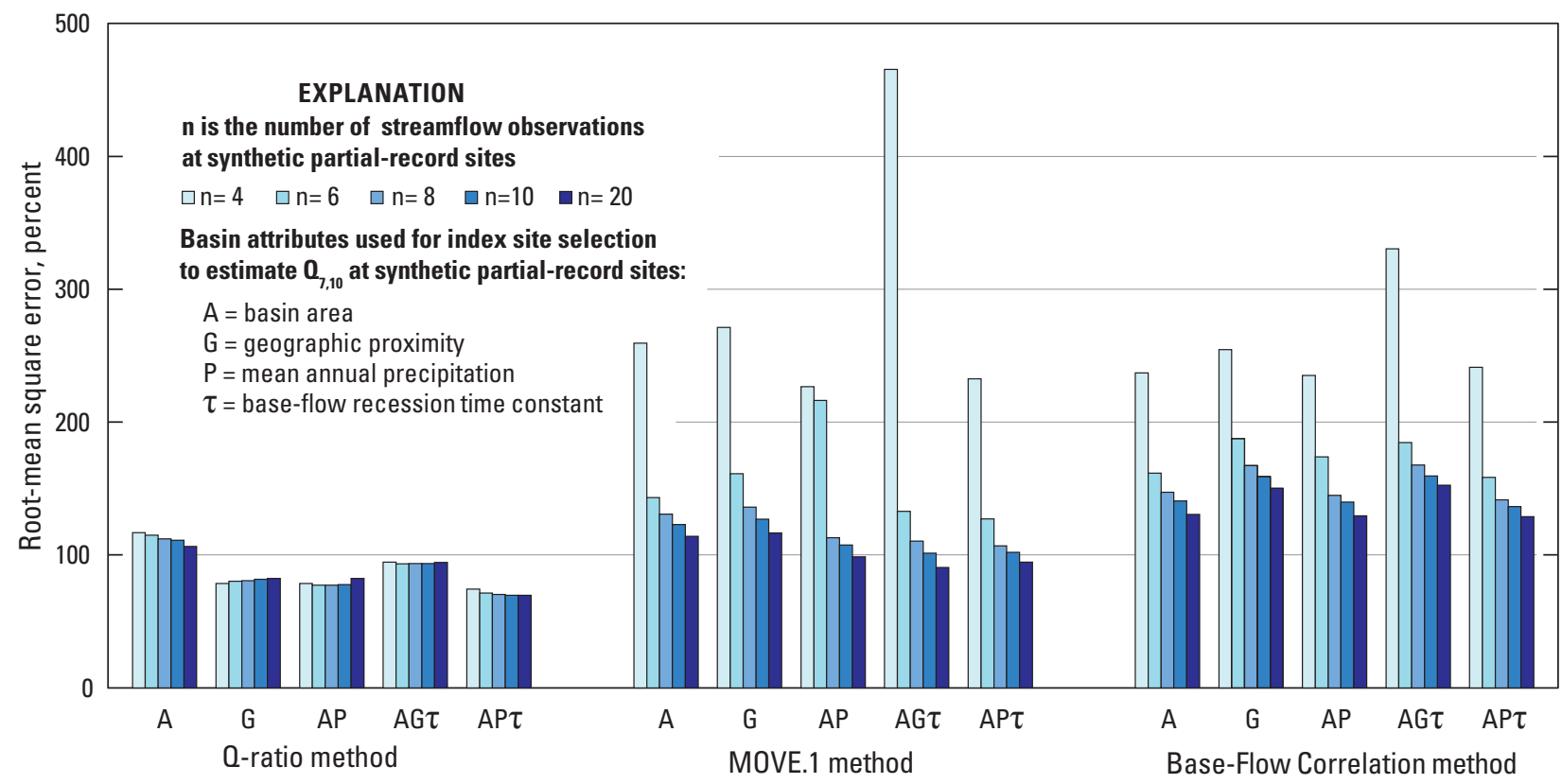

Figure 11. Root-mean square error of three correlation methods (Q-ratio, MOVE.1, and Base-Flow Correlation) in estimating the $0_{7,10}$ at partial-record sites in western Washington, using scenarios defined by the number of streamflow observations $(\mathrm{n})$ and the combination of basin attributes used to select an index site.

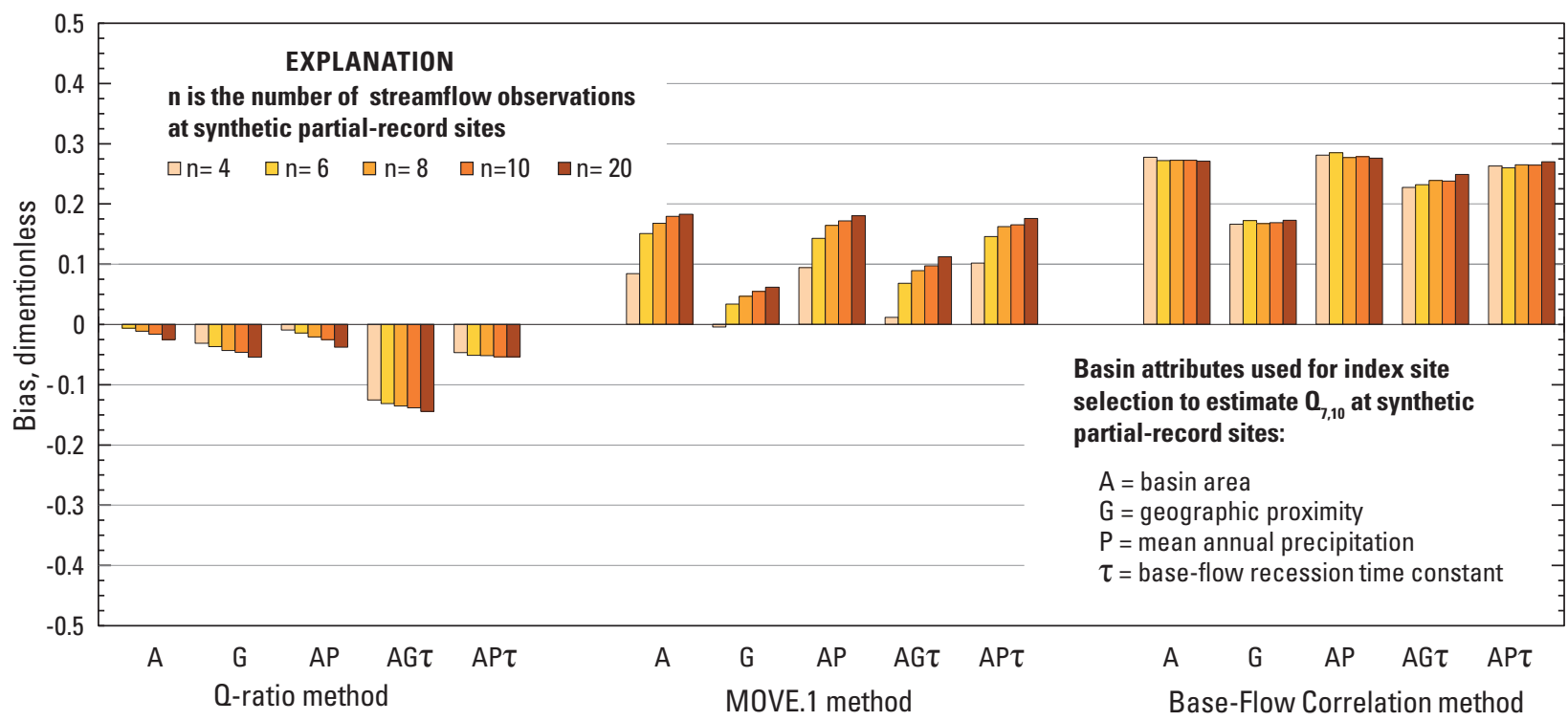

Figure 12. Overall bias associated with three index-site correlation methods (0-ratio, MOVE.1, Base-Flow Correlation) in estimating the $0_{7,10}$ at partial-record sites in western Washington, using scenarios defined by the number of streamflow observations and the combination of basin attributes used to select an index site. 


\section{Incorporation of $\tau$ and Partial-Record Streamflow-Measurement Sites into Regional Low-Flow Regression Models}

Previous studies have demonstrated the value of including $\tau$ as an explanatory variable in regional regression models for estimating low-flow characteristics at ungaged sites (for example, Bingham, 1986; Vogel and Kroll, 1992; and Funkhouser and others, 2008). For basins with continuous recording gaging stations, a reliable estimate of $\tau$ is readily calculated from the daily streamflow record. Where the continuous streamflow-gaging network is not represented, either geographically or outside the range of explanatory variables, estimates of $\tau$ can be calculated at partial-record sites to extend network coverage. For partial-record sites, $\tau$ can be estimated using equation 1 , with measurement pairs made on the receding limb of the hydrograph during baseflow conditions. In establishing partial-record sites, however, questions arise as to where sites should be located, what types of basins to include, and, once a site is established, the number of measurements needed to reliably estimate $\tau$.

To answer these questions, a series of regional lowflow regression models were developed for the sole purpose of evaluating the benefits of including $\tau$ as an explanatory variable (which has implications for the types of streams to measure as well as their geographic locations) and determining the optimum number of observations for estimating $\tau$ at partial-record sites. Regression models for estimating the $\mathrm{Q}_{7,10}$ at ungaged sites were developed using basin area $(A)$, mean annual precipitation $(P)$ and $\tau$ as explanatory variables and the $\mathrm{Q}_{7,10}$ derived from 65 continuous streamflow-gaging stations (the 43 index sites and 22 discontinued gaging stations) in western Washington with 7 or more years of daily streamflow record. Three regression models developed using an ordinary least-squares (OLS) method (which is considered sufficient for purposes of the analysis) were evaluated using the performance metric of RMSE expressed as a percentage (fig. 13). The three regression models estimate $\mathrm{Q}_{7,10}$ as a function of $A, P$, and $\tau$ as:

$$
\begin{array}{ll}
Q_{7,10}=0.15 A^{1.27}, & R^{2}=0.74, \\
Q_{7,10}=8.48 \times 10^{-4}\left(A^{1.17} P^{1.23}\right), & R^{2}=0.79,
\end{array}
$$

and

$Q_{7,10}=6.47 \times 10^{-6}\left(A^{0.968} P^{1.16} \tau^{1.68}\right), \quad R^{2}=0.90$,

where $Q_{7,10}$ is the low-flow characteristic (the lowest average streamflow for a consecutive 7-day period that recurs on average once every 10 years ) in cubic feet per second, $A$ is basin area in square miles, $P$ is mean annual precipitation in inches, $\tau$ is the base-flow recession time constant in days, and
$R^{2}$ is the coefficient of determination. In the empirical Monte Carlo analysis, $\tau$ was calculated from 500 randomly sampled observation pairs to obtain the best estimate $\left(\tau_{\text {ideal }}\right)$, and from a much smaller number of observation pairs ranging from 1 to 10 to represent the estimate at a partial-record site.

The RMSE of the regression models generally decreases as the number of explanatory variables increases, and the fraction of variation explained by the regressions $\left(R^{2}\right)$ increases with the incorporation of additional variables. For example, the regression model that uses only $\mathrm{A}$ as an explanatory variable has an RMSE of 133 percent, and the regression model that uses $\mathrm{A}$ and $\mathrm{P}$ as explanatory variables has an RMSE of 114 percent. By incorporating $\tau$ as a third explanatory variable, the RMSE is further reduced to possibly as small as 72 percent, depending on the number of paired streamflow measurements that were used to determine $\tau$. Eight measurement pairs are optimal for estimating $\tau$ at partial-record sites, after which additional measurements yield diminishing effects in lowering the RMSE.

Although the OLS regression method was adequate for evaluating explanatory variables and optimizing the number of measurement pairs for estimating $\tau$ (at partial-record sites), this method assumes that the $\mathrm{Q}_{7,10}$ determined at continuous gaging stations and partial-record sites is equally accurate. This is not usually the case, however, as sites with long streamflow records (for example, long-term continuous gaging stations) will generally provide more reliable estimates of $\mathrm{Q}_{7,10}$ than sites with only a few years of record or several low-flow measurements (such as partial-record sites). For this reason, use of the weighted least-squares (WLS) method is preferable for developing regional low-flow regressions that include partial-record sites because WLS allows sites with more reliable estimates of the $\mathrm{Q}_{7,10}$ to have more influence in determining the regression model. Software tools such as the Weighted-Multiple-Linear Regression (WREG) Program (Eng and others, 2009; U.S. Geological Survey, 2011b) have been developed by the USGS to assist users in generating WLS regressions and could be used for determining future low-flow regressions for western Washington as the number of fully developed partial-record sites (sites with eight or more measurement pairs to reliably estimate $\tau$ ) increases.

The ability of regional regression models to accurately estimate low-flow characteristics at ungaged sites over a large range of stream types and geography depends on the extent of the regional streamflow-gaging-station network. Regression models generally provide better estimates of lowflow characteristics at ungaged sites when basin attributes are well represented in the data set from which the regressions were developed. Results from this study indicate that partialrecord sites can be used to efficiently fill gaps and expand the coverage of the streamflow-gaging network for specific basin attributes such as $\tau$, thereby extending the applicable range of regression models for estimating low-flow characteristics at ungaged sites in western Washington (fig. 14). 


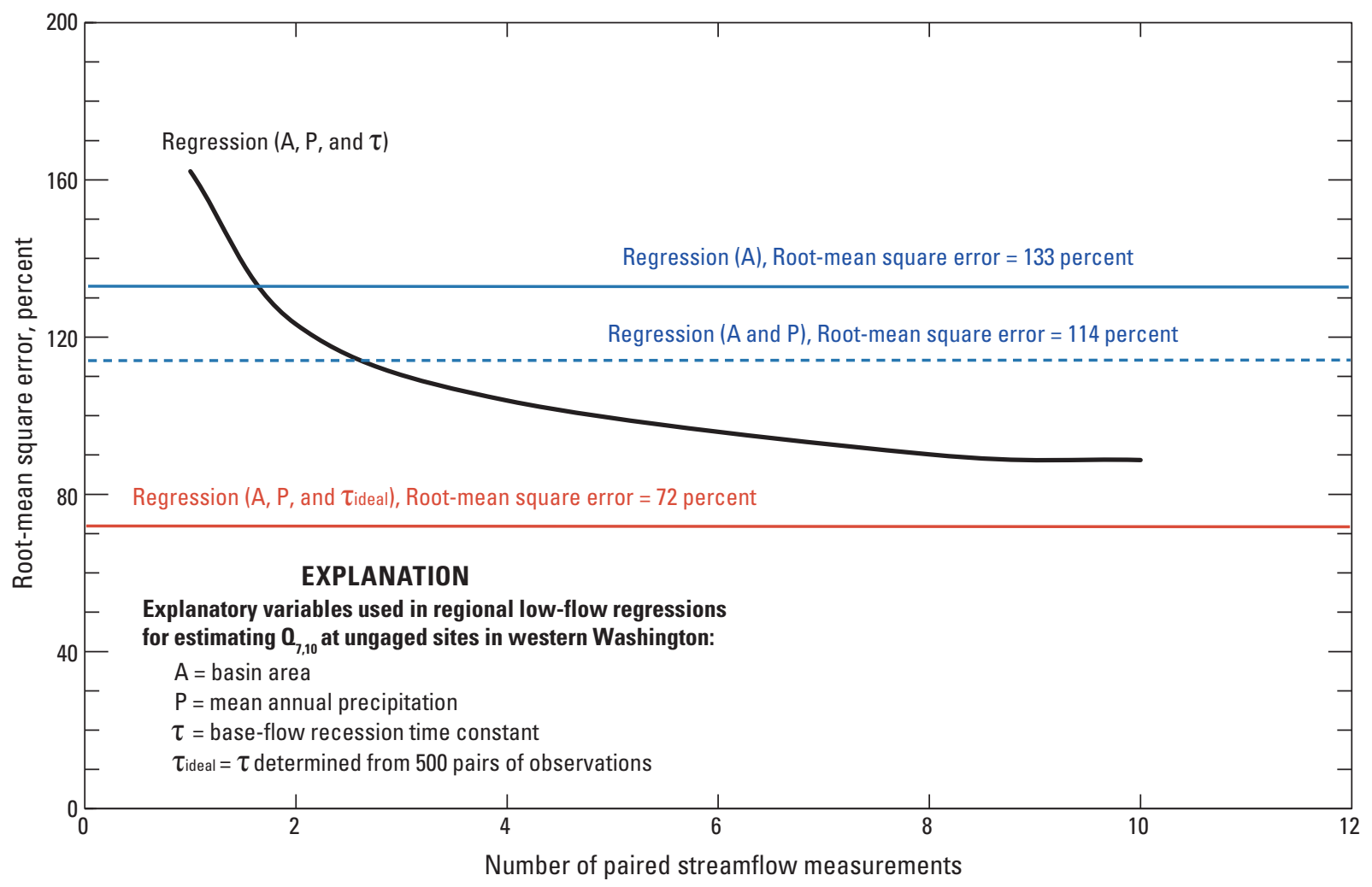

Figure 13. Root-mean square error of regression models for estimating the $0_{7,10}$ at ungaged sites in western Washington, using different combinations of explanatory variables and numbers of paired streamflow measurements.

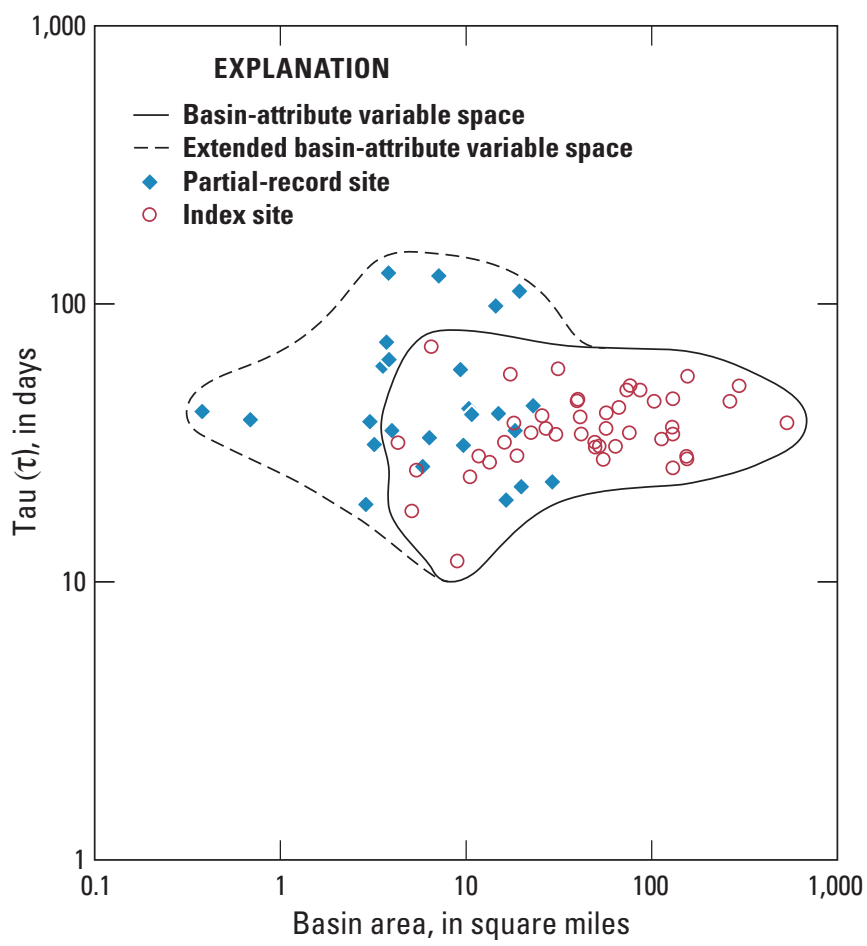

Figure 14. Coverage of basin-attribute variable space defined by basin area and $\tau$ for index sites and partialrecord sites established during 2007-09 low-flow surveys in western Washington. 
A low-flow survey strategy that includes measurements of $\tau$ at partial-record sites requires additional effort and planning, but has the potential to reduce the error of regional regression models for estimating low-flow characteristics at ungaged sites. As Vogel and Kroll (1992) point out, however, regression models that include $\tau$ as an explanatory variable present a problem in that an estimate of $\tau$ first must be made for the ungaged site. To accomplish this, previous researchers have mapped $\tau$ on a regional scale using interpolation (Bingham, 1986) and more specifically, kriging methods (Funkhouser and others (2008). Regionalization of low-flow characteristics through regression also assumes stationarity of watershed and climatic conditions and does not account for potential trends in streamflow (Milly and others, 2008).

\section{Summary}

As part of a scientific framework for assessing water resources in western Washington, the Northwest Indian Fisheries Commission (NWIFC) and its member tribes identified documentation of low-flow conditions in western Washington streams as a high priority. To document the low flows, a regional low-flow survey of small streams was initiated by the NWIFC, NWIFC-member tribes, and Point-No-Point Treaty Council in cooperation with the U.S. Geological Survey (USGS) in 2007, and repeated by the tribes during the low-flow seasons (July-September) of 2008 and 2009. As part of the survey, flow was measured at 63 stream sites; the number of measurements made at each site ranged from 1 to 10 . A strategy of making paired measurements during receding base flows was used to compute the base-flow recession time constant, or $\tau$, at 25 sites. The $\mathrm{Q}_{7,10}$, defined as the lowest average streamflow for a consecutive 7 -day period that recurs on average once every 10 years, was estimated at stream sites using either the Q-ratio or MOVE.1 correlation method, and required concurrent daily mean streamflows from index sites that were selected from the USGS streamflowgaging-station network on the basis of basin similarity. Generally, partial-record and miscellaneous sites established during the low-flow surveys are in smaller drainage areas, generate less runoff, and have correspondingly lower values of $\mathrm{Q}_{7,10}$ than do most continuous streamflow-gaging stations in the network.

The accuracy of index-site correlation methods (Q-ratio, MOVE. 1 and Base-Flow Correlation) in estimating the $\mathrm{Q}_{7,10}$ at 43 index sites was evaluated using an empirical Monte
Carlo technique for different scenarios, each defined by the number of streamflow measurements and the combination of basin attributes used to select an index site. Of the three correlation methods, Q-ratio had the smallest root-mean square error (RMSE), which ranged from 70 to 118 percent for all scenarios, and the optimum number of streamflow measurements for estimating the $\mathrm{Q}_{7,10}$ at partial-record sites was four, with only slight reductions in the RMSE gained by additional measurements.

By incorporating $\tau$ as an explanatory variable in regional low-flow regressions, the regression RMSE for estimating the $\mathrm{Q}_{7,10}$ at ungaged sites can be reduced to as low as 72 percent, 42 percent lower than if only basin area and mean annual precipitation are used as explanatory variables. In practice, if partial-record sites are included in the regression data set, $\tau$ must be estimated from pairs of base-flow recession measurements. The Monte Carlo analysis also determined that eight is the optimum number of measurement pairs for estimating $\tau$ at partial-record sites, after which additional measurements yield diminishing effects in lowering the RMSE.

Partial-record sites offer an affordable way to expand the geographic coverage of low-flow information in a region and include combinations of basin attributes (for example, small, low-elevation streams) that are underrepresented in the streamflow-gaging-station network. A low-flow survey strategy that includes measurements of $\tau$ at partial-record sites requires additional effort and planning, but has the potential to significantly reduce the error of regional regression models for estimating low-flow characteristics at ungaged sites in western Washington.

\section{Acknowledgments}

The authors gratefully acknowledge the efforts of the following individuals (and their respective tribal governments or agencies), who collected and provided streamflow data as part of the low-flow surveys in western Washington (200709): Warren Scarlett (Hoh Indian Tribe), Ann Savery (Tulalip Tribes), John Konovsky (Squaxin Island Tribe), Steve Todd (Point-No-Point Treaty Council), Sarah Burlingame (Port Gamble S'Klallam Tribe), Lynn Doremus (Nooksack Indian Tribe), Jody Brown (Stillaguamish Tribe of Indians), Scott Morris (Sauk-Suiattle Indian Tribe), Elsie Wescott (Puyallup Tribe of Indians), and Tyson Waldo (Northwest Indian Fisheries Commission). 


\section{References Cited}

Bent, G.C., and Steeves, P.A., 2006, A revised logistic regression equation and an automated procedure for mapping the probability of a stream flowing perennially in Massachusetts: U.S. Geological Survey Scientific Investigations Report 2006-5031, 107 p.

Bingham, R.H., 1986, Regionalization of low-flow characteristics of Tennessee streams: U.S. Geological Survey Water-Resources Investigations Report 85-4191, $63 \mathrm{p}$.

Brutsaert, Wilfried, and Nieber, J.L., 1977, Regionalized drought flow hydrographs from a mature glaciated plateau: Water Resources Research, v. 13, p. 637-643.

Collings, M.R., and Hidaka, F.T., 1974, Low-flow characteristics of streams in the Willapa Bay drainages, Washington: U.S. Geological Survey Water Resources Investigation Report 74-8, 16 p.

Cummans, J.E., 1977, Low-flow characteristics of streams on the Kitsap Peninsula and adjacent islands, Washington: U.S. Geological Survey Open-File Report 76-704, 19 p.

Curran, C.A., and Olsen, T.D., 2009, Estimating low-flow frequency statistics and hydrological analysis of selected streamflow-gaging stations, Nooksack River basin, northwestern Washington and Canada: U.S. Geological Survey Scientific Investigations Report 2009-5170, 44 p.

Dragovich, J.D., Dunn, A.B., Parkinson, K.T., Kahle, S.C., and Pringle, P.T., 1997, Quaternary stratigraphy and crosssections, Nooksack, Columbia, and Saar Creek Valleys, Kendall and Deming 7.5-minute quadrangles, Western Whatcom County, Washington: Washington Division of Geology and Earth Resources Open-File Report 97-4, 13 p.

Eng, Ken, Chen, Yin-Yu, and Kiang, Julie, 2009, User's guide to the weighted-multiple-linear regression program (WREG version 1.0): U.S. Geological Survey Techniques and Methods, book 4, chap. A8, 21 p.

Eng, Ken, and Milly, P.C.D., 2007, Relating low-flow characteristics to the base-flow recession time constant at partial record stream gauges: Water Resources Research, v. 43, 8 p., W01201, doi:10.1029/2006WR005293.

Funkhouser, J.E., Eng, Ken, and Moix, M.W., 2008, Lowflow characteristics and regionalization of low-flow characteristics for selected streams in Arkansas: U.S. Geological Survey Scientific Investigations Report 2008$5065,161 \mathrm{p}$.
Hamilton, D.A., Sorrell, R.C., and Holtschlag, D.J., 2008, A regression model for computing index flows describing the median flow for the summer month of lowest flow in Michigan: U.S. Geological Survey Scientific Investigations Report 2008-5096, 43 p.

Harris, D.D., 1977, Hydrologic changes after logging in two small Oregon coastal watersheds: U.S. Geological Survey Water-Supply Paper 2037, 31 p.

Haushild, W.L., and LaFrance, D.E., 1977, Low-flow characteristics of streams on the Olympic Peninsula, Washington: U.S. Geological Survey Open-File Report 77-812, 29 p.

Hidaka, F.T., 1973, Low-flow characteristics of streams in the Puget Sound region, Washington: U.S. Geological Survey Open-File Report 72-163, 56 p.

Hirsch, R.M., 1982, A comparison of four streamflow record extension techniques: Water Resources Research, v. 18, no. 4, p. 1081-1088.

Hortness, J.E., 2006, Estimating low-flow frequency statistics for unregulated streams in Idaho: U.S. Geological Survey Scientific Investigations Report 2006-5035, 40 p.

Jones, M.A., 1999, Geologic framework of the Puget Sound aquifer system, Washington and British Columbia: U.S. Geological Survey Professional Paper 1424-C, 31 p.

Konrad, C.P., 2005, Scientific framework for a comprehensive assessment of tribal water resources in western Washington: U.S. Geological Survey Open-File Report 2005-1390, 16 p.

Konrad, C.P., and Booth, D.B., 2005, Hydrologic changes in urban streams and their ecological significance, in Brown, L.R., Gray, R.H., Hughes, R.M., and Meador, M.R., eds., Effects of urbanization on stream ecosystems: American Fisheries Society Symposium 47, Bethesda, Md., p. 157-177.

Konrad, C.P., Brasher, A.M.D., and May, J.T., 2008, Assessing streamflow characteristics as limiting factors on benthic invertebrate assemblages in streams across the western United States: Freshwater Biology v. 53, doi: 10.1111/j.1365-2427.2008.02024.x, p. 1983-1998.

Lane, R.C., 2009, Estimated water use in Washington, 2005: U.S. Geological Survey Scientific Investigations Report 2009-5128, $30 \mathrm{p}$.

Linneman, Scott, Pittman, Paul, and Vaugeois, Laura, 2007, Lively landscapes-Major Holocene geomorphic events in the Nooksack-Sumas Valley, in Stelling P., and Tucker, D.S., eds., Floods, Faults and Fire- Geological field trips in Washington State and southwest British Columbia: Geological Society of America Field Guide 9, p. 99-119. 
Milly, P.C.D., Betancourt, Julio, Falkenmark, Malin, Hirsch, R.M., Kundzewicz, Z.W., Lettenmaier, D.P., and Stouffer, R.J., 2008, Climate change - Stationarity is dead-Whither Water management?: Science, v. 319, no. 5863, p. 573-574.

Potter, K.W., 2001, A simple method for estimating baseflow at ungaged locations: Journal of the American Water Resources Association, v. 37, no. 1, p. 177-184.

Rantz, S.E., 1982, Measurement and computation of streamflow: U.S. Geological Survey Water Supply Paper 2175, v.1, 284 p.

Ries, K.G., III, and Friesz, P.J., 2000, Methods for estimating low-flow statistics for Massachusetts streams: U.S. Geological Survey Water-Resources Investigation Report 00-4135, 81 p.

Riggs, H.C., 1972, Low-flow investigations: U.S. Geological Survey Techniques of Water Resources Investigations, book 4, chap. B1, $18 \mathrm{p}$.

Risley, John, Stonewall, Adam, and Haluska, Tana, 2008, Estimating flow-duration and low-flow frequency statistics for unregulated streams in Oregon: U.S. Geological Survey Scientific Investigations Report 2008-5126, 22 p.

Searcy, J.K., 1959, Flow-duration curves-Manual of hydrology_Part 2, low-flow techniques: U.S. Geological Survey Water Supply Paper 1542-A, 33 p.

Sinclair, K.A., and Pitz, C.F., 1999, Estimated base-flow characteristics of selected Washington rivers and streams: Washington State Department of Ecology Water Supply Bulletin No. 60 (pub. No. 99-327), 24 p., accessed April 2, 2008, at http://www.ecy.wa.gov/biblio/99327data.html.

Stedinger, J.R., and Thomas, W.O., Jr., 1985, Low-flow frequency estimation using base-flow measurements: U.S. Geological Survey Open-File Report 85-95, 22 p.

Tasker, G.D., 1987, Comparison of methods for estimating low flow characteristics of streams: Water Resources Bulletin, 23, no. 6, p. 1077-1083.

The MathWorks Inc., 2008, MATLAB Version 7.6.0.324 (R2008a).

U.S. Census Bureau, 2000, Census 2000, Washington by county: U.S. Census Bureau database accessed May 5, 2010, at http://factfinder.census.gov/servlet/ GCTTable? bm=y\&-geo id=04000US53\&- box head nbr $=$ GCT-PH1\&-ds name $=$ DEC_2000_SF1_U\&$\underline{\text { redoLog }=\text { false \&-mt name }=\text { DEC } 2000 \text { SF1_U GCTPH1 }}$ $\underline{\text { ST7\&-format }=\text { ST-2. }}$.
U.S. Environmental Protection Agency, 2011, WaterBASINS 4.0: U.S. Environmental Protection Agency database, accessed February 29, 2012, at http://water.epa. gov/scitech/datait/models/basins/b3webdwn.cfm.

U.S. Geological Survey, 1985, Low-flow frequency estimation at partial-record sites: Office of Surface Water Technical Memorandum No. 86-02, accessed May 15, 2009, at http:// water.usgs.gov/admin/memo/SW/sw86.02.html and http:// water.usgs.gov/osw/pubs/sw86.02.attachment.pdf.

U.S. Geological Survey, 2010, StreamStats: U.S. Geological Survey database, accessed February 29, 2012, at http:// water.usgs.gov/osw/streamstats/Washington.html.

U.S. Geological Survey, 2011a, National Water Information System: U.S. Geological Survey database, accessed February 29, 2012, at http://waterdata.usgs.gov/nwis.

U.S. Geological Survey, 2011b, Weighted-Multiple-Linear Regression (WREG) Program, ver. 1.02: U.S. Geological Survey software, accessed February 29, 2012, at http:// water.usgs.gov/software/WREG/.

U.S. Weather Bureau, 1965, State of Washington, mean annual precipitation, 1930-1957: Portland, Oreg., Soil Conservation Service, map M-4430, 1 sheet [no scale].

Vaccaro, J.J., Hansen, A.J., and Jones, M.A., 1998, Hydrogeologic framework of the Puget Sound aquifer system, Washington and British Columbia: U.S. Geological Survey Professional Paper 1424-D, 77 p.

Vogel, R.M., and Kroll, C.N., 1992, Regional geohydrologicgeomorphic relationships for the estimation of low-flow statistics: Water Resources Research, v. 28, no. 9, p. 24512458.

Williams, J.R., Pearson, H.E., and Wilson, J.D., 1985a, Streamflow statistics and drainage basin characteristics for the Puget Sound region, Washington, volume 1: U.S. Geological Survey Open-File Report 84-144A, 420 p.

Williams, J.R., Pearson, H.E., and Wilson, J.D., 1985b, Streamflow statistics and drainage basin characteristics for the Puget Sound region, Washington, Volume 2: U.S. Geological Survey Open-File Report 84-144B, 320 p. 


\section{Appendix A. Measurements At Partial-Record And Miscellaneous Streamflow- Measurement Sites For Low-Flow Surveys In 2007, 2008, And 2009}

During the 2007-09 low-flow surveys, 283 streamflow measurements were made by the Northwest Indian Fisheries Commission (NWIFC), NWIFC-member tribes, Point-No-Point Treaty Council, and U.S. Geological Survey (USGS) (2007 only). Measurements were made in perennial streams that are not part of the USGS streamflow-gaging-station network, using various types of current meters, and following streamflow-measurement methods outlined by Rantz (1982). All measurements are listed in table A1.

\section{Reference Cited}

Rantz, S.E., 1982, Measurement and computation of streamflow: U.S. Geological Survey Water Supply Paper 2175, v. 1, 284 p. (Also available at http://pubs.er.usgs.gov/publication/wsp2175 vol1.) 


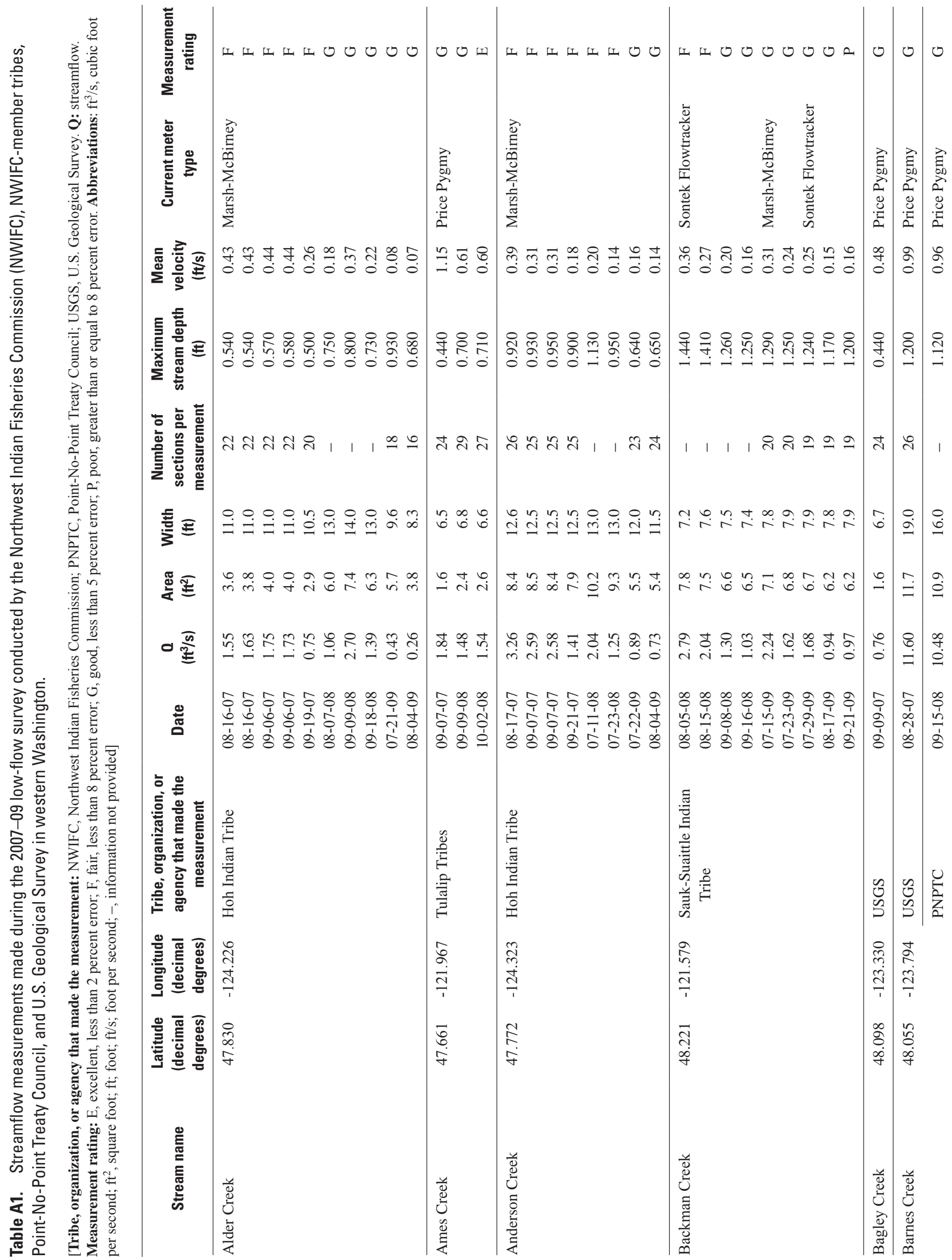




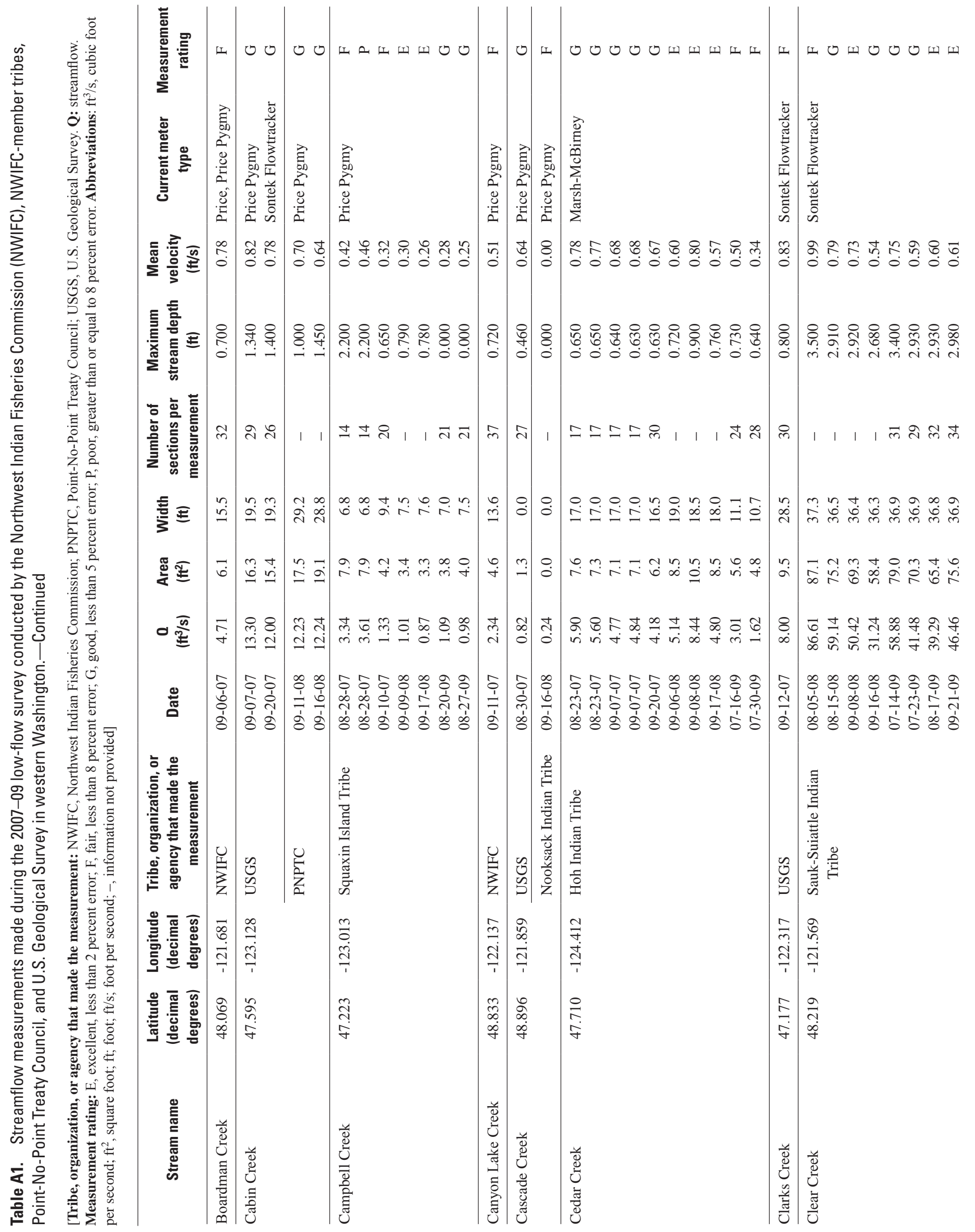




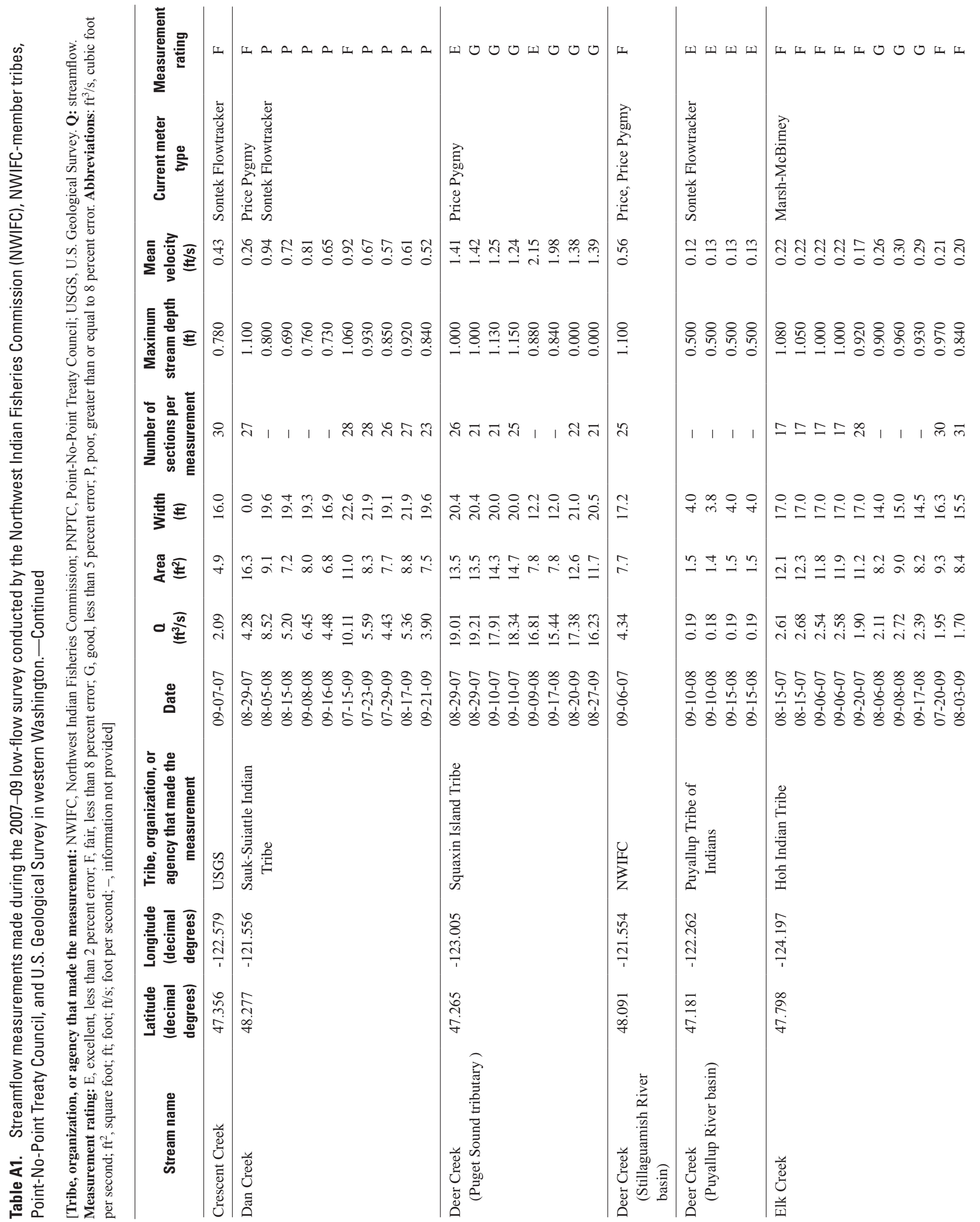




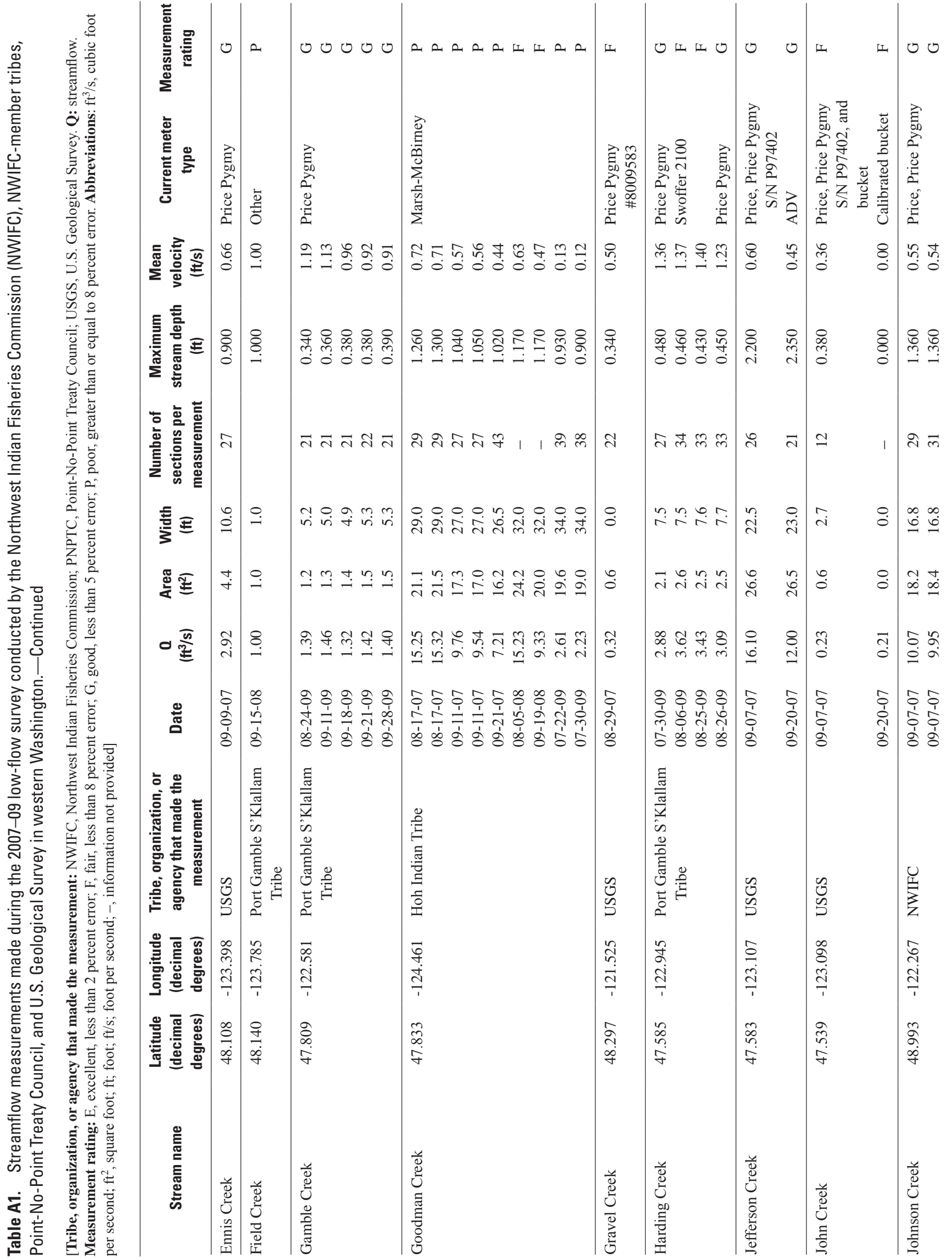




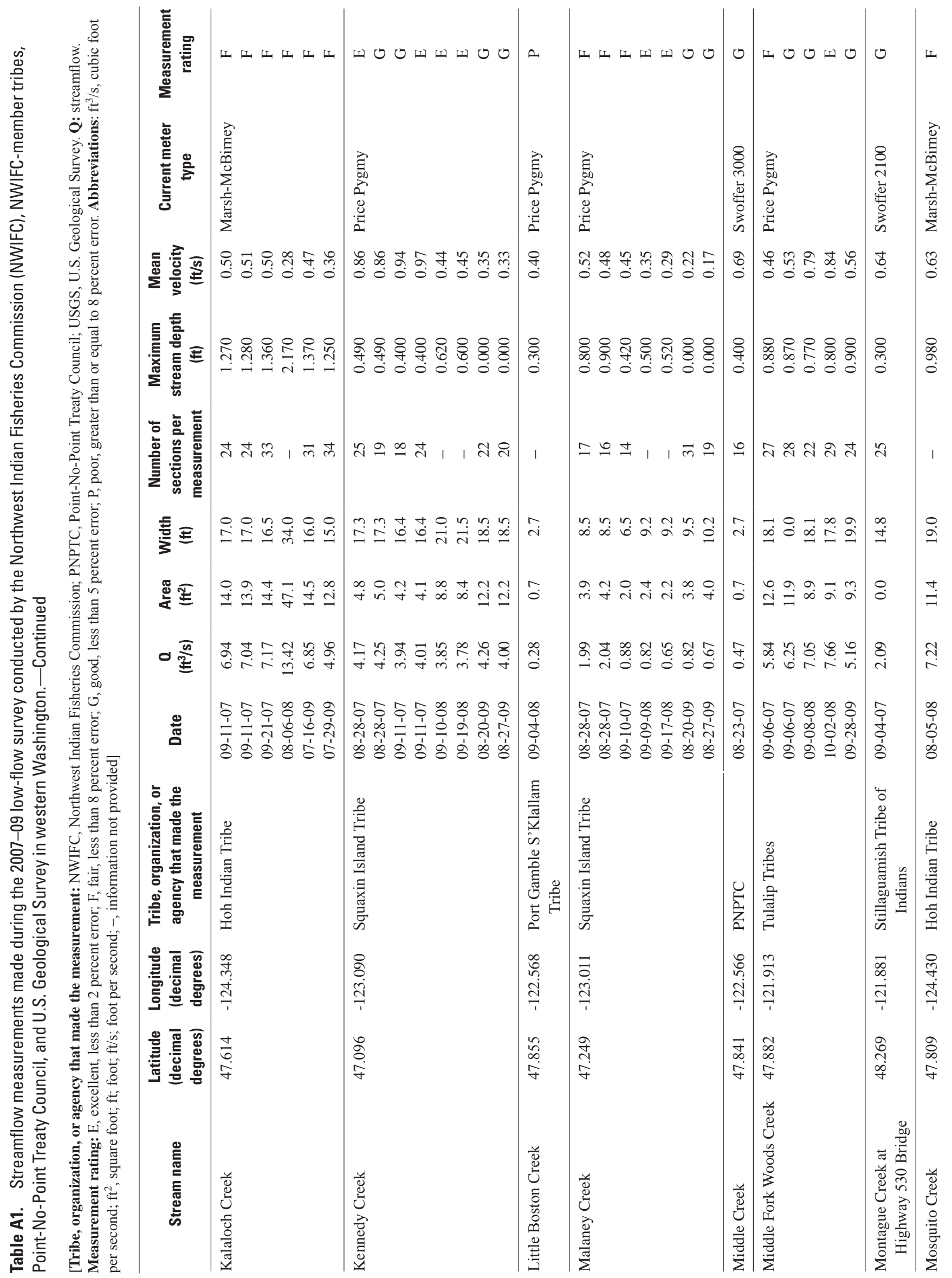




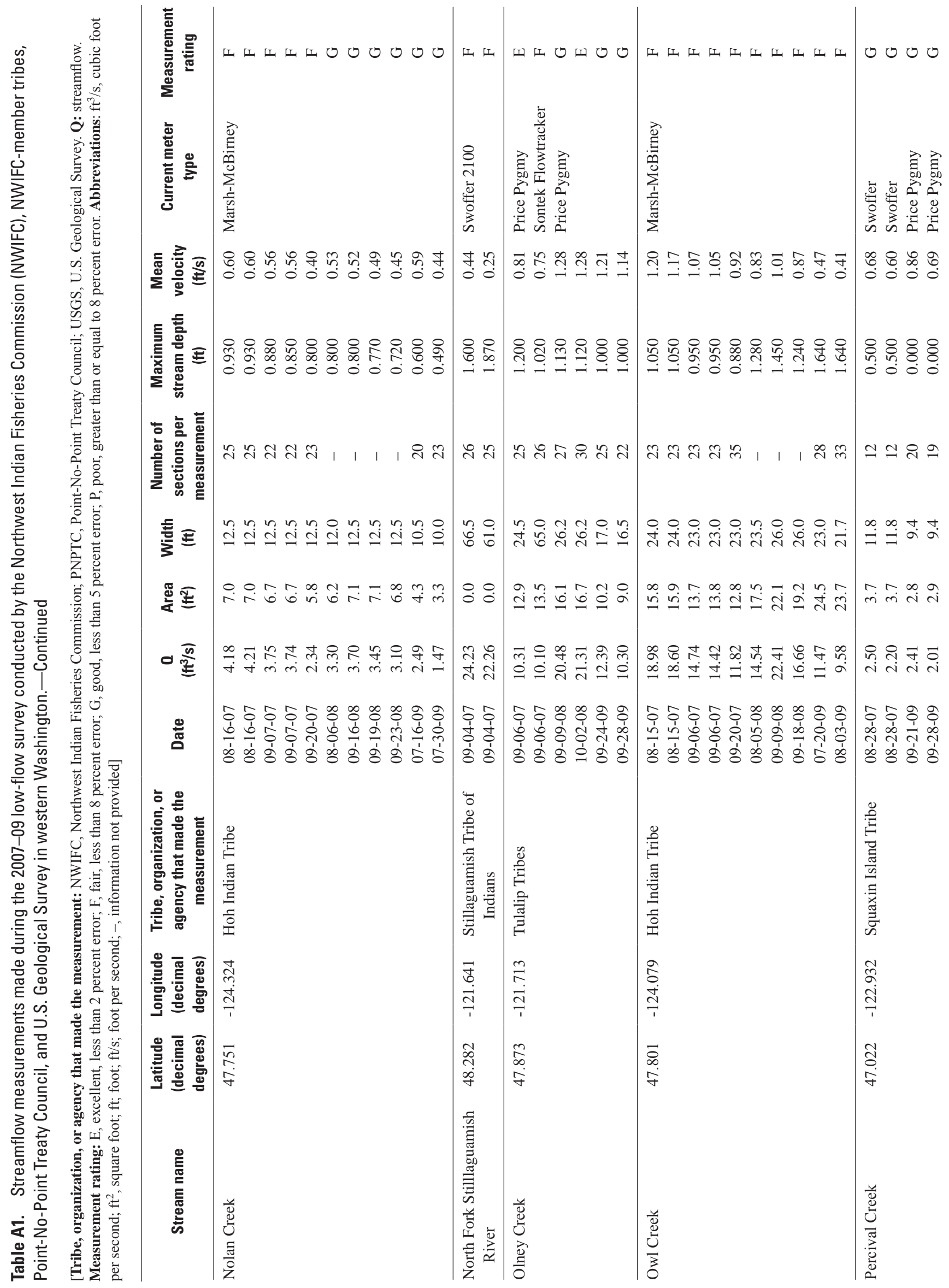




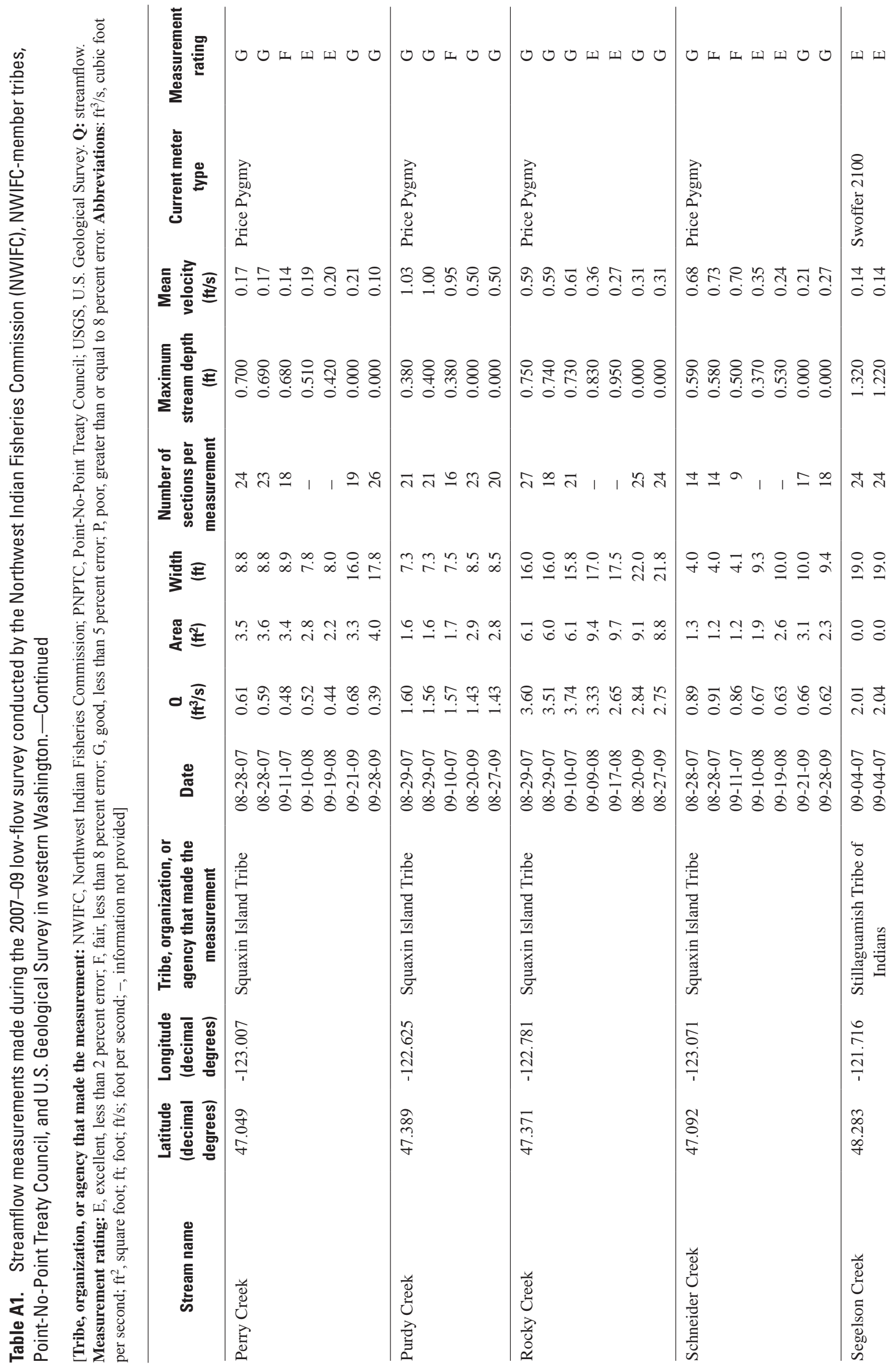




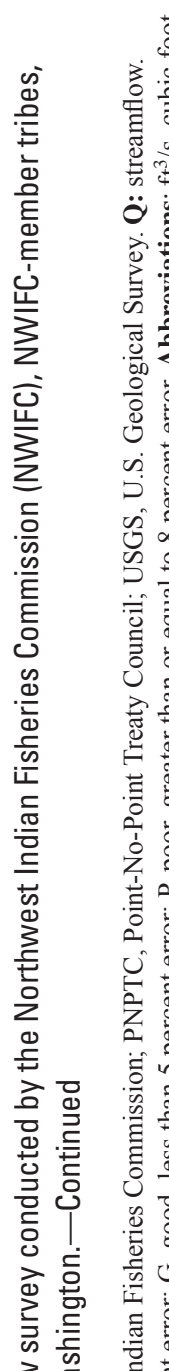

方

기옹

웅

흥.

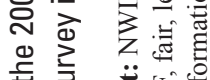

के 可

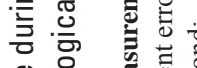

응 응

E

क ज

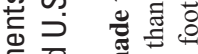

틀 므

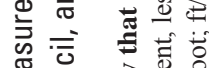

岇

उ

产

के

을 를

غं 을

高

年

宅 章

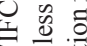

항

ثี

है है

总

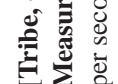
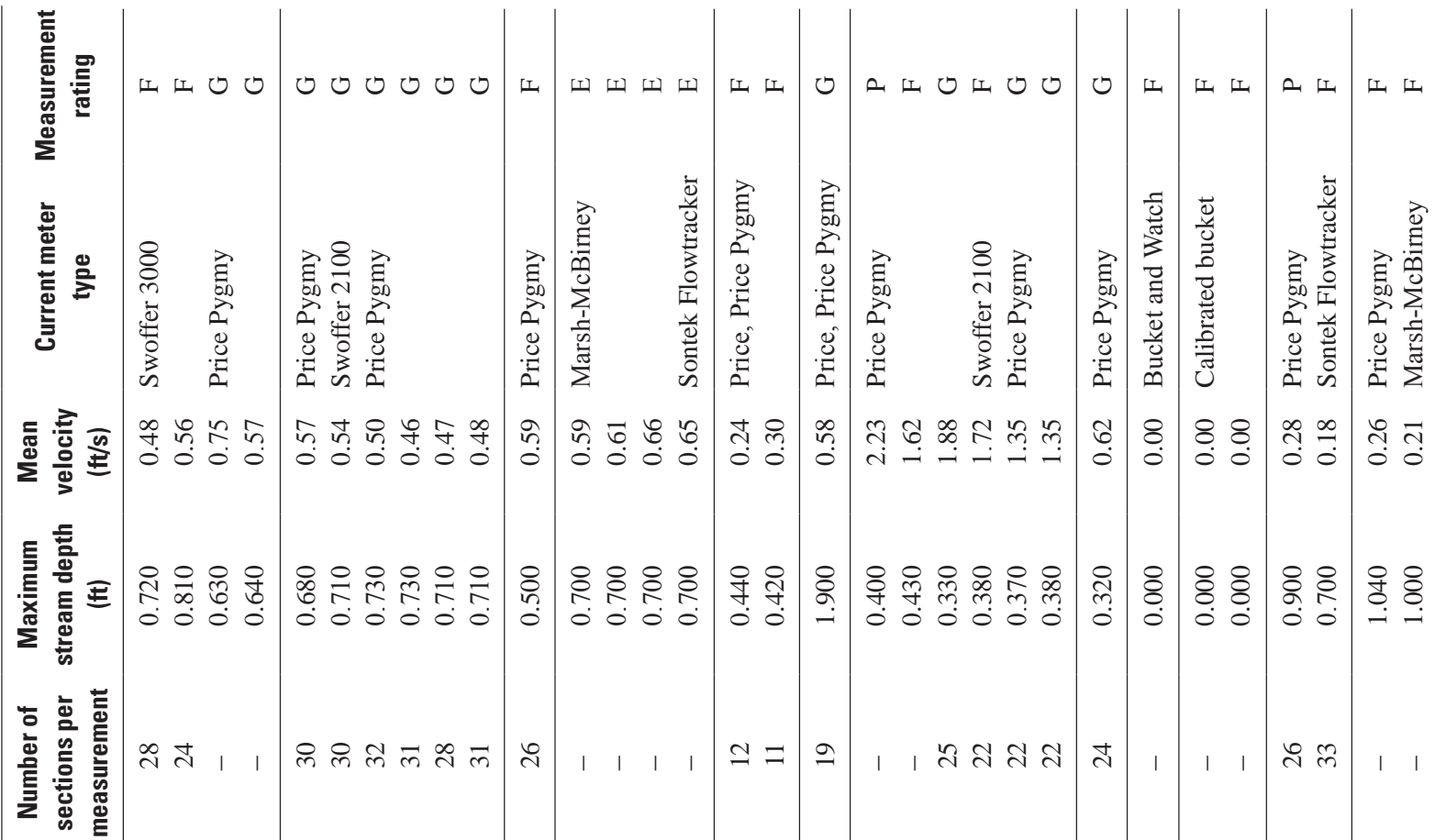

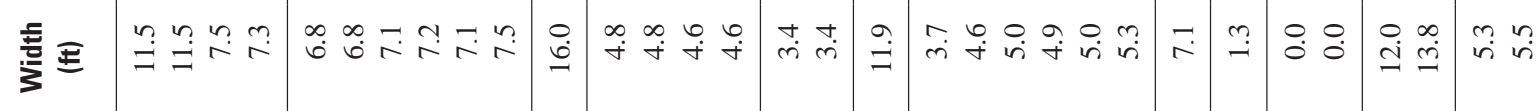

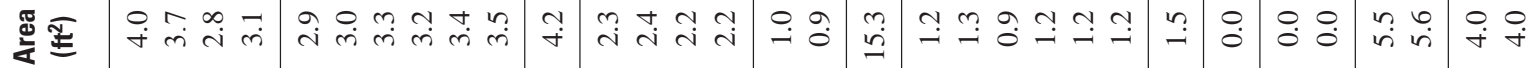

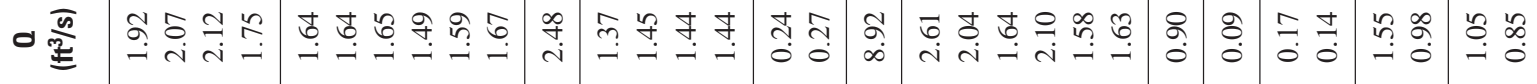

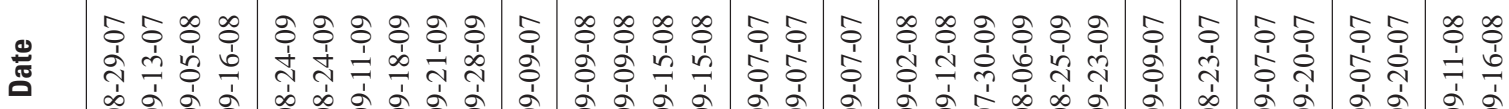
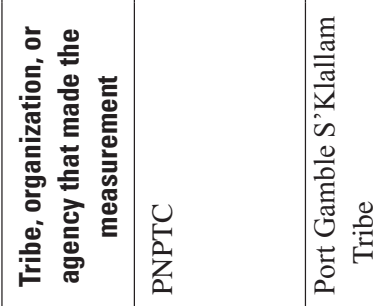

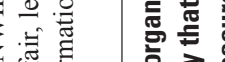

플

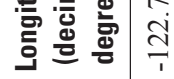

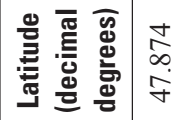

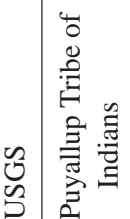

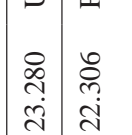

กิ

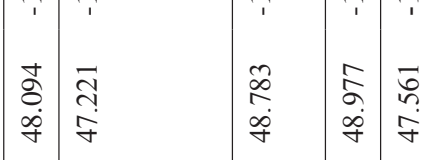
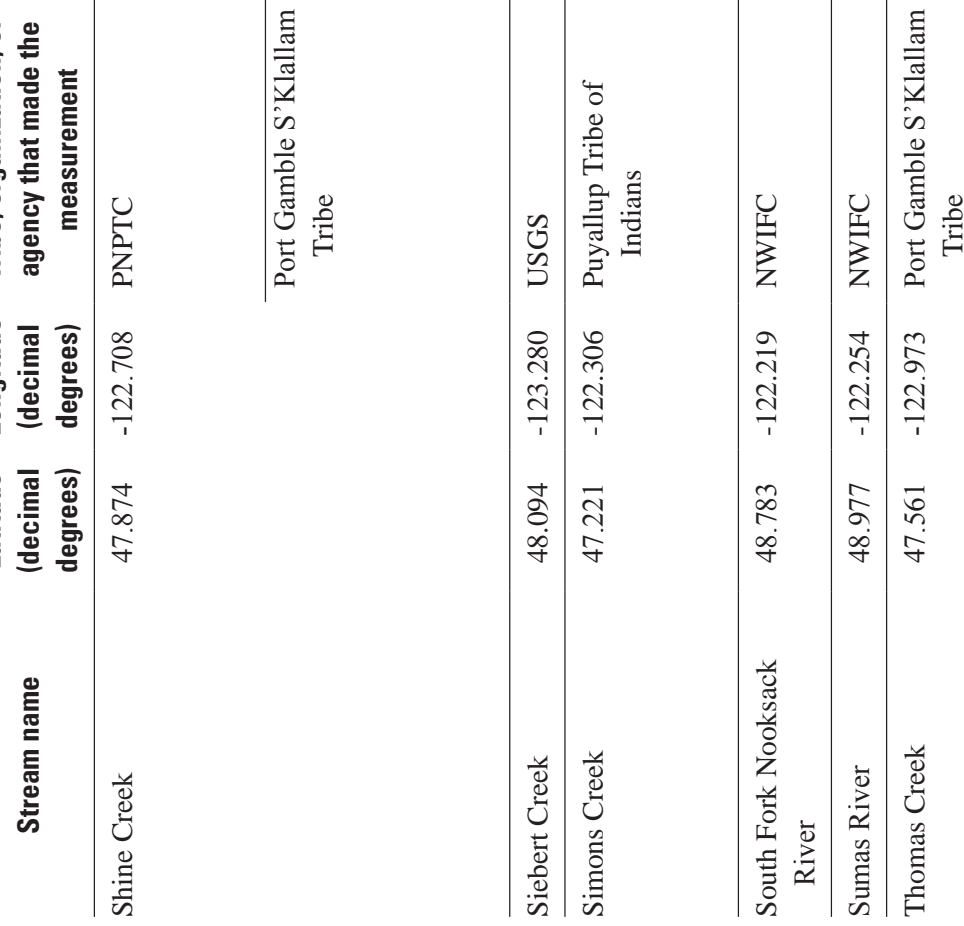
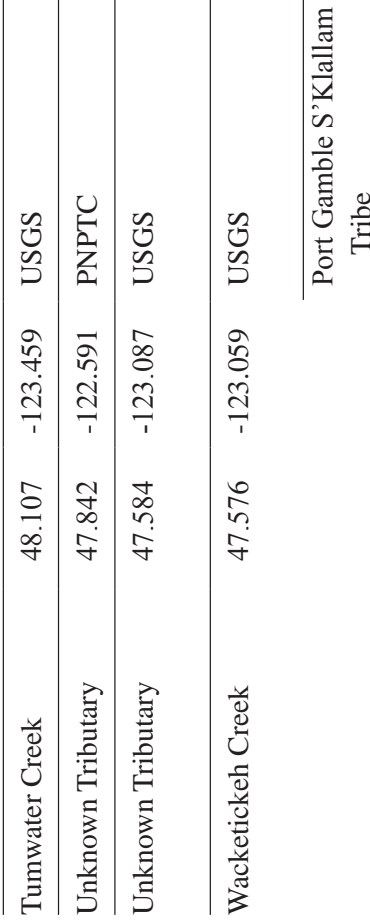


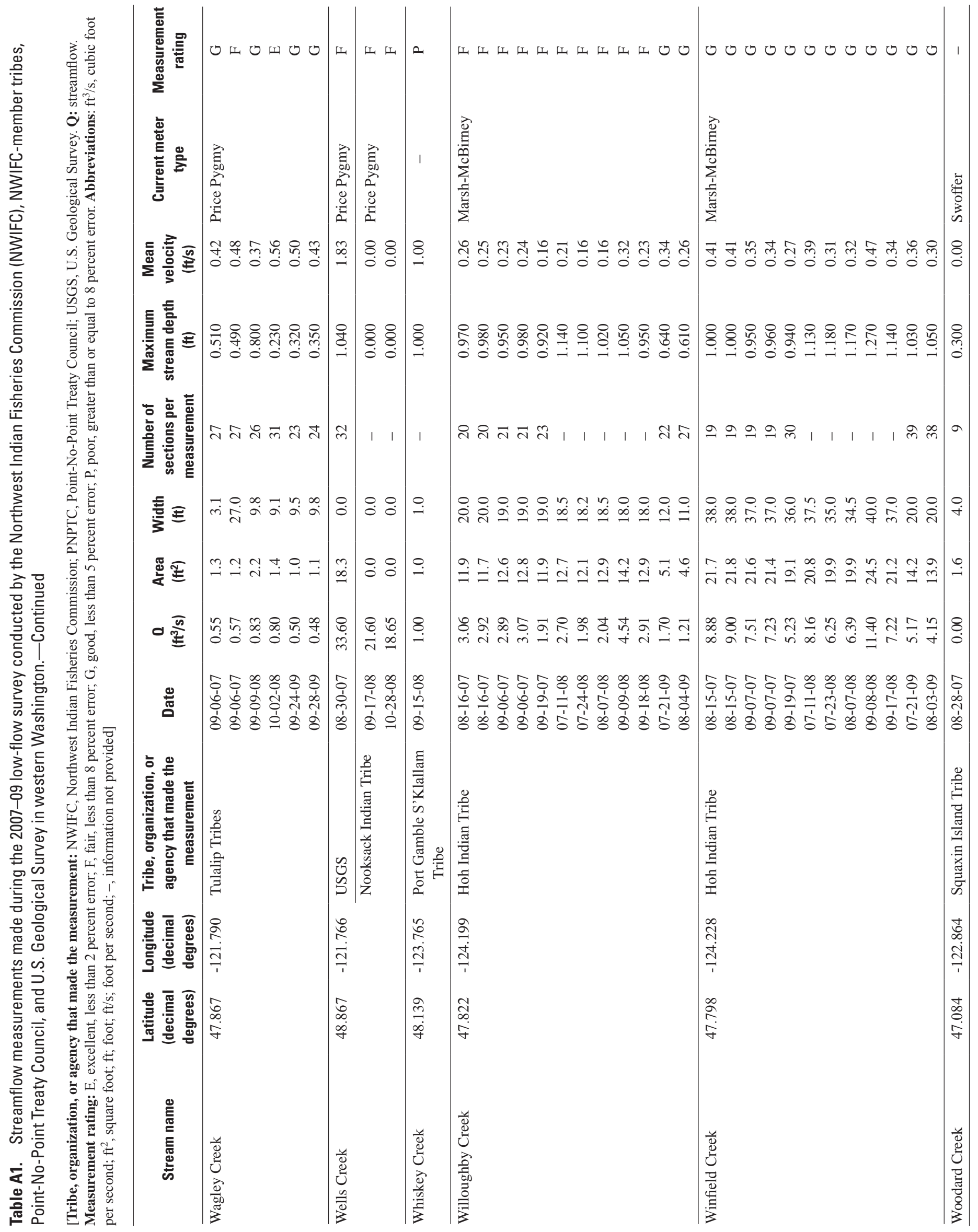


Publishing support provided by the U.S. Geological Survey

Publishing Network, Tacoma Publishing Service Center

For more information concerning the research in this report, contact the

Director, Washington Water Science Center

U.S. Geological Survey

934 Broadway, Suite 300

Tacoma, Washington 98402

http://wa.water.usgs.gov 
